\title{
NORTH AMERICAN SPECIES OF TWO-WINGED FLIES BE- LONGING TO THE TRIBE MILTOGRAMMINI
}

\author{
By Harry W. Allen \\ Of the Mississippi Agricultural Experiment Station
}

\section{INTRODUCTION}

An attempt has been made in this paper to define the limits of a small group of Muscoid flies which have long been associated, somewhat incorrectly, by most American workers in Diptera with the family Tachinidae, and to render the species of the group thus defined readily determinable.

In the American literature of the past 30 years, with the exception of Townsend's, the genera which are discussed in this paper have been rather widely scattered among genera of Tachinidae with which they are but distantly related. Owing to the difficulty of obtaining a clear conception from the existing literature, of the limits of the group, and of the genera contained, it has been found advisable to define and redescribe quite fully. A special effort has been made in the generic descriptions to disregard characters which fall within the range of specific variation, and to make the limits of the genera, which fortunately are more readily distinguished than in the great central mass of either the Sarcophagidae or Tachinidae, broad enough to include not only the known species, but others as yet unknown, of which there must still be many. In the genera to which new species have been added, the old species not adequately defined have been quite fully redescribed.

It has been found necessary to change the generally accepted nomenclature and the synonomy to a considerable extent, from two causes; first the failure of earlier workers, doubtless handicapped by the lack of properly determined European material, to recognize the identity of certain American forms with previously described European species, and secondly, the inclusion in one genus, namely Hilarella, of several heterogenous Nearctic elements each of which is very evidently entitled to generic rank. While Coquillett's conception of the genera of this group has been adhered to in most cases, the author has recognized some of Townsend's genera not hitherto generally accepted.

No. 26I0.-Proceedings U. S. National Museum, Vol. 68, ARt. 9 $54292-26 \dagger-1$ 
The types of very nearly all the species described by Coquillett and Townsend, most of which are deposited in the United States National Museum, have been examined. Prof. S. J. Hunter of the University of Kansas very kindly loaned Townsend's types deposited there, for examination. A study of these revealed that three of the types, long submerged in synonomy, undoubtedly represent distinct species, but in most the synonomy of Coquillett and of Aldrichwas confirmed. Van der Wulp's types of Mexican and Central American species which are located in the British Museum, were not seen, but correspondence with the museum cleared up some of the uncertainty surrounding these species. It is to be regreted that the position of Miltogramma erythrura and M. nana of Van der Wulp could not be unquestionably settled at this time. The types of species described by Meigen, Rossi, Fallen, and Zetterstedt were not seen, and their present location is not known to me, but most represent well known European species, of which I have seen determined specimens from several European workers, and about the identity of which there can be little doubt. Macquart's types of the North American Metopia lateralis and Senotainia rubriventris were not seen and their present location is not known. However, very fortunately, both may be quite certainly distinguished from the other known species by the original description.

In the course of the work on this group, considerable scattered information has been secured on the morphology of the immature stages, which has been submitted for the purpose of clearing away some of the uncertainty regarding the taxonomic position of the Miltogramminae. Notes on the biology of certain species have also been included.

To Dr. J. M. Aldrich, I am most deeply indebted for so freely placing the facilities of the United States National Museum at my disposal, and for frequent consultations and much correspondence, at the cost of much inconvenience and loss of time to himself. To Prof. S. J. Hunter, I am also very deeply indebted for the loan of type material from the University of Kansas Museum, the examination of which has contributed materially to the accuracy of this paper. I am indebted to C. W. Johnson for the opportunity to examine his fine collection, and that of the Boston Natural History Society, as well as for much helpful correspondence on the group; to Prof. M. Bezzi of Italy, who loaned for study specimens of several European genera of Miltogramminae not known in the North American fauna; to Doctor Zerny, who loaned for study North American material deposited in the Imperial Museum at Vienna, which included the type of Arrenopus americanus; to Maj. E. E. Austen and his assistants in the British Museum for helpful correspondence concerning Van der Wulp's types; to Prof. R. W. 
Harned, of Agricultural and Mechanical College of Mississippi, for providing an opportunity to study collections in the Eastern States, to J. R. Ricks, director of the Mississippi Agricultural Experiment Station, for allowing time for the completion of the manuscript; and to Prof. E. W. Stafford for much helpful criticism. Thanks are due, also, to Nathan Banks, J. R. Malloch, Prof. J. S. Hine, C. Howard Curran, H. J. Reinhard, C. S. Brimley, A. F. Burgess, Dr. H. T. Fernald and R. C. Shannon for allowing me to examine their collections or the collections in their charge.

\section{CLASSIFICATION}

\section{Family SARCOPHAGIDAE}

\section{Subfamily Miltogramminae}

The Miltogramminae are a group of Muscoid flies closely related both to the Tachinidae and the Sarcophagidae, but in both morphology and habits, more closely resembling the latter. The adults may be distinguished from any Tachinidae that have come under my observation, by the presence of an undivided postscutellum (fig. 1, $B, m t^{2}$, compare with $A$ and $C$ ) the possession of an enlarged second sternite which overlaps the tergite of the first abdominal segment ${ }^{1}$ on the sides (fig. 2, $B, 2 s$, compare with $A$ and $C$ ). From the Sarcophaginae they may be distinguished, usually, by the Tachinid habitus, and by the arista, which is naked or at most with inconspicuous plumosity scarcely longer than the thickness of the arista. The outer forceps of the male genitalia are usually several times as long as wide and approximate or exceed the inner forceps in size; whereas in the Sacophaginae they are reduced to the so-called "accessory plate."

The Miltogramminae of North America may be divided into two tribes on the following adult characters:

1. Impression of the bucca, near the vibrissal angle, large, conspicuously submerged below the surface level of surrounding sclerites, color of impression usually contrasting conspicuously with that of the parafacials and remainder of bucca; orbital bristles present on females, but usually lacking on males; mesotibia on outer front surface near the middle usually with more than one macrochaeta.

Tribe Amobiini

Impression of bucca, near vibrissal angle, small, not deeply submerged or conspicuously differentiated by color from the parafacials and the remainder of the bucca; orbital bristles present in both sexes or lacking in both males and females; mesotibia on outer front surface near the middle with never more than a single marcochaeta; sternopleuron at most with two bristles; abdomen without discal macrochaetae_.................. Tribe Miltogrammini

${ }^{1}$ Actually the second abdominal tergite, the first having been reduced to a vestigial sclerite. Most taxonomic workers in calypterate Muscoidea refer to the first plainly visible segment as the first abdominal segment, which is the procedure adopted in this paper. Compare Young, Cornell Agricultural Experiment Station, Mem. 44, figs. 38 to $76,1921$. 


\section{Tribe MILTOGRAMMINI}

Small to medium sized flies, usually with rather short wings and a short, conical abodmen. Ocellar bristles usually differentiated, proclinate. Orbital bristles present in both sexes except in Pachyophthalmus, in which they are submerged in a second row of frontals; but one frontal row of bristles on either side of vitta, except in Pachyophthalmus. Penultimate joint of arista not more than twice as long

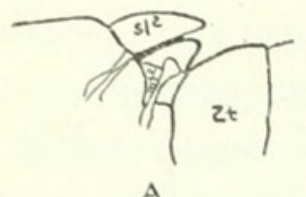

A

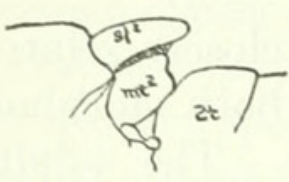

B

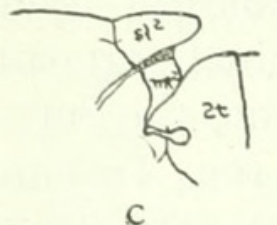

Fig. 1.-VARIATION IN TEE STRUCTURE OF THE MEDITERGITE OR POSTSCUTELLUM. LATERAL ASPECT.

$A$, Tachinida ( TACHINA MELLA WALKER), $B$, MILTOGRAMMINAE (SENOTAINIA TRILINEATA VAN DER WULP), $C$, SARCOPHAGINAE (SARCOPHAGA COMMUNIS PARKER); $m t^{2}$, postscutellum $s l^{2}$, SCUTELlum, $2 t$ FIRST ABDOMINAL SEgMENT. $A$, AND $C$ ADAPTED FROM YOUNG. as wide. Bucca and back of head about the oral cavity never with a distinct white beard, at most with sparse pale hairs. Eyes bare. Abdomen always bearing macrochaetae. Females with nonpiercing larvipositors. Male genitalia (pls. 1-3) with penis not so highly chitinized nor so intricately sculptured as in typical Sarcophaginae; comparatively small and unspecialized, tipped with a membraneous, more or less collapsible hood; two pairs of claspers present, the posterior clasper usually bearing a stout bristle. Apical cell (pl. 4, fig. 24) ending far before the extreme tip of the wing, sometimes closed at margin of wing but never long petiolate. Fourth vein with a strong fold at the bend.

The females in all species that have been studied, possess a very short uterus (pl. 4, figs. 20, 22, 25), from which arises a large pouch, in which the ova develop to large, naked, active maggots, of which there is only a moderate number. The female reproductive organs conform in all species studied to the Group III of Pantel, ${ }^{2}$ and the somewhat more restricted Metopiine series of Townsend. ${ }^{3}$

The larvae in all instars resemble the unspecialized Muscoid maggot in general appearance. The first instar maggots are metapneustic, the posterior spiracle being at the bottom of a depression; the buccopharyngeal apparatus (pl. 5, figs. 29-34) consists of a single large, heavily chitinized, median hook, articulating with a slender dorsal rod of the intermediate region, and two much weaker, thinly chitinized lateral hooks, one on either side of the median; the intermediate region is fused to the basal piece without articulation. The second and third instar maggots are amphipneustic, the anterior spiracle (pl. 5, fig. 28) consisting of several fingerlike papillae radiating like the rays of a fan. In the last two instars, the median hook of

${ }^{2}$ Diptères à larves entomobies, LaCellule, vol. 26, p. 57, 1910.

${ }^{3}$ An. Ent. Soc. Amer., vol. 4, p. 130, 1911. 
the buccopharyngeal apparatus (pl. 5, fig. 34) is absent or vestigial, and the two divergent lateral hooks are strong and heavily chitinized; two articulations, one between the hooks and the intermediate piece and another between the intermediate piece and the basal piece, are present; and above the intermediate region is a small rodlike dorsal accessory piece.

The puparium (pl. 4, fig. 21) is smooth and evenly rounded save at the anterior end which sometimes shows distinct segmentary folds, and the posterior end which is somewhat constricted and truncate at the apex. At the anal end there is usually a deep pit (pl. 5, fig. 27), in which the posterior spiracles are located. The spiracle is pierced by three nearly straight, more or less converging slits.

The adults occur on barren sand, rocks, denuded soil, or less frequently on herbaceous vegetation and low shrubby foliage. Some

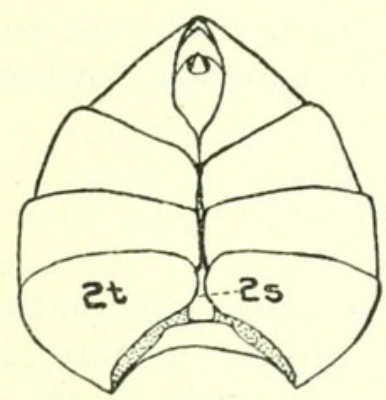

A

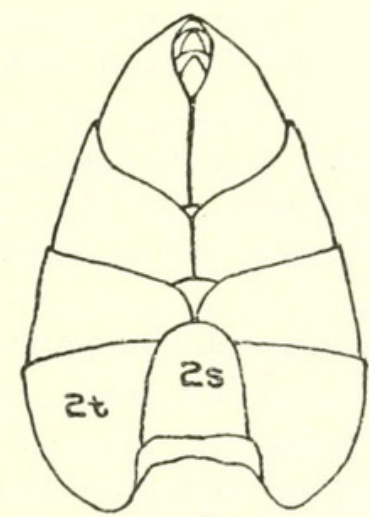

B

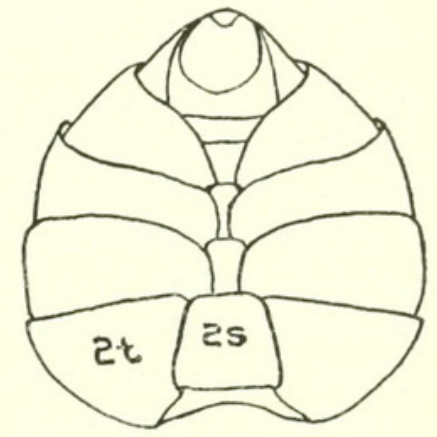

C

Fig. 2. VENTRAL VIEW OF ABDOMEN TO SHOW VARIATION IN THE DEVELOPMENT AND POSITION OF THE second sternite. A, Tachinidae (Frontina alfitae Riley), B, Miltogramminae (Senotainia trilineata VAN der Wulp), $C$, SARCophaginae (SARCophaga, Species), $2 t$ tergite of First Seg MENT, $2 s$, SECOND STERNITE REDUCED AND SUBMERGED BENEATH TERGITE IN TACHINIDAE, ENLARGED AND OVERLAPPING TERgite IN MiltogramminaE AND SARCOHPAGINAE.

are attracted to flowers, others to the flow of honey dew from aphids or other Hemipterous insects. The females are viviparous, depositing active, motile maggots on or near their food. The maggots live in the nests of fossorial Hymenoptera, feeding on the stores provided for their young, which may be paralyzed insects or spiders, or masses of pollen. The maggots are not known to be primary parasites of the young of their Hymenopteron hosts, though their presence in the nests frequently results in the death of the latter. So far as I am aware, it has not yet been conclusively demonstrated that any of these files are the primary parasites of phytophagous insects in their native habitat. All the records investigated by the writer indicate that while the flies do breed in the bodies of such hosts, they display no interest in them until after they have become the prey of some wasp. 
1. First vein bare

First vein bristly; distal section of fifth vein more than half as long as preceding section; parafacials bearing a distinct row of macrochaetae, facial ridges nearly parallel ............................ Opsidiopsis Townsend.

2. Length of head at vibrissae almost equal to length at base of antennae; epistoma usually produced, and in profile conspicuously visible _............. 12.

Length of head at vibrissae much less than at base of antennae; epistoma not

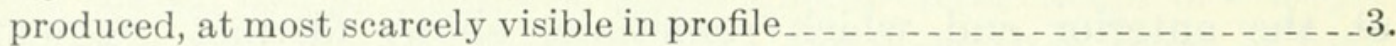

3. Apical cell open at margin of wing

Apical cell closed at margin of wing

4. Distal section of fifth vein longer than preceding section; fold of fourth vein longer than diseal cell _........................ Taxigramma Perris.

Distal section of fifth vein scarcely more than half as long as preceding section; fold of fourth vein distinctly shorter than discal cell_.._Hilarella Rondani.

5. Facial ridges with bristly hairs or macrochaetae which extend not more than one-fourth the distance from the vibrissae to the base of the antennae_..._- 6 .

Facial ridges with strong macrochaetae which extend more than half the distance from the vibrissae to base of antennae; vibrissae and ocellar bristles distinctly differentiated; bristly hairs on either side of frontal vitta below ocellus_...

6. Parafacials with a distinct row of macrochaetae

Parafacials without macrochaetae _._.

7. Abdomen elongate conical; macrochaetae on abdomen much larger than the

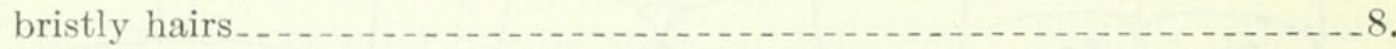

Abdomen subglobose; macrochaetae on abdomen scarcely differentiated from the surrounding bristly hairs; head in profile with no definite angle between buccal and facial margin_._._._._._._. Oestrohilarella Townsend.

8. Frontal rows not extending to below base of antennae and not strongly divergent below; lunule scarcely visible_............................ 9 .

Frontal rows extending to middle of second antennal joint and strongly divergent below; lunule conspicuously exposed.

Phrosinella Robineau-Desvoidy.

9. Third vein on upper surface with but one or two small hairs near its base; arista thickened to near its tip....................... Senotainia Macquart.

Third vein on upper surface usually with a row of bristles extending at least nearly halfway to the small cross vein; if not, arista not thickened beyond basal half _._._.

10. Apical scutellar bristles well developed, nearly or quite as large as the extreme lateral scutellars; front with sides not converging anteriorly; male genitalia, in repose, largely or wholly concealed within tip of abdomen.

Gymnoprosopa Townsend.

Apical scutellar bristles lacking, or if present, much smaller than the other two pairs of marginals; front with sides usually converging anteriorly; male genitalia, in repose, extruding prominently from tip of abdomen.

Eumacronychia Townsend.

11. Facial ridges strongly divergent; vibrissae much less than length of second antennal joint above front edge of oral margin; proboseis much shorter than height of head.

Metopia Meigen.

Facial ridges parallel; vibrissae at least length of second antennal joint above front edge of oral margin; proboscis at least nearly as long as height of head.

Opsidia Coquiliett. 
12. Facial ridges usually with bristly hairs; macrochaetae if present, not extending on ridges above tips of antennae

Facial ridges with a row of macrochaetae extending far above tips of antennae.

Sphenometopa Townsend.

13. A single row of frontal bristles on either side of frontal vitta; orbital bristles present_...

Two rows of frontal bristles on either side of frontal vitta; orbital bristles absent_................ Pachyophthalmus Brauer and Bergenstamm.

14. Distance from tip of antennae to vibrissae equal to or exceeding length of second antennal joint; antennae extending scarcely more than half way from their base to front edge of oral margin; posterior, convex part of sternopleuron triangular in outline; mesothoracic spiracle with both fringes of about equal size, the posterior one not plumose_._. _ _ Senotainia Macquart.

Distance from tips of antennae to vibrissae distinctly less than length of second antennal joint; antennae more than two-thirds distance from their base to front edge of oral margin _............ Eumacronychia Townsend.

\section{DESCRIPTIONS OF GENERA AND SPECIES}

\section{Genus PACHYOPHTHALMUS Brauer and Bergenstamm}

Pachyophthalmus Brauer and Bergenstamm, Denkschr. Akad. Wien., vol. 56 , p. 117 , 1889; vol. 60 , p. 170, 1893. Genotype, Tachina signata Meigen.-Coquillett, U. S. Bur. Ent., Tech. Ser., no. 7, p. 79, 1897.Adams, in Williston's North American Diptera, pp. 372, 373, fig. 151, nos. 72, 75, 1908.-Thompson, Paris Edition du Bull. Biol. de la France et de la Belgique, Recherches sur les Diptères parasites, pp. 138-149, 1921.

Sarcomacronychia Townsend, Trans. Amer. Ent. Soc., vol. 19, p. 100, 1892. Genotype, S. unica Townsend, which equals $P$. floridensis Townsend, according to J. M. Aldrich, who has examined both of Townsend's types.

The genus is represented in North America by four closely related species. The adults in general appearance closely resemble Sarcophaga adults. Other characters are as follows:

The inner eye orbits are broadly convex, without sinuosity, somewhat more nearly approximated at base of antennae than at the vertex, diverging rapidly to bucca; front much narrower than either eye, slightly narrower in female than in male; two frontal rows on either side of vitta, the inner row scarcely attaining base of antennae, and not suddenly divergent below, composed of larger bristles than those of outer row; no orbital bristles in either sex; vibrissae high above front edge of oral margin; antennae short, extending scarcely more than halfway to the oral margin; third joint less than three times the second; penultimate joint of arista not more than twice as long as broad; length of head at vibrissae nearly equals length at base of antennae; facets of eye at extreme front very much larger than those at the side; bucca and back of head beset with black bristly hairs; no pale hairs present. Thorax with three broad, conspicuous black vittae; two sternopleurals, and three pairs of nearly equal marginal scutellar bristles. Intermediate abdominal segments marked with large, irregular blackish spots. Genitalia of male 
moderately large; in repose protruding but slightly from tip of abdomen; inner forceps divergent from near their base; posterior claspers bearing bristles; penis with a more or less rigid, noncollapsible, heavily chitinized hood; genitalia of female consisting of a relatively unspecialized larvipositor, telescoped within abdomen in repose. Wings lacking costal spine; veins without bristles save a few at base of third vein; apical cell narrowly open, ending far before extreme wing tip; section of fourth vein beyond the bend strongly arcuate; last section of fifth vein much less than half the preceding section. Pulvilli of male nearly or quite as long, of female much shorter than last tarsal joint.

Townsend ${ }^{4}$ dissected one species of the genus and found that it possessed the typical double-pouched uterus of Miltogramminae. The writer has dissected dried specimens of floridensis, finding in them considerable numbers of maggots, indicating that the females deposit active larvae. Not all the larvae found were fully formed, a definite series from partly to fully developed first instar maggots being present.

Thompson's description and figures of signatus ${ }^{5}$ indicates that in the first instar larvae, the cuticle covering, save near the mouth, takes the form of oval or polygonal, convex rugosities differing from the covering of flattened scales followed by longitudinal ribs found in Miltogramma and Senotainia. The buccopharyngeal apparatus of signatus, as figured by Thompson, closely resembles that of Senotainia, excepting that the whole mechanism is more massive and the median hook lacks the ventral denticle. I find that the buccopharyngeal apparatus of floridensis differs slightly from Thompson's figure for signatus in possessing a more slender intermediate piece and differently shaped lateral hooks. Thompson finds that the buccal armature of the third instar very closely resembles that of Sphecapata conica and Miltogramma punctatum; that there are seven radiating papillae on the anterior spiracle, and that the posterior spiracle possesses the usual three oval slits.

The puparium of floridensis has been carefully described and figured by Greene, ${ }^{6}$ who finds that the posterior end bears a small, deep pit, within which occur the posterior spiracles. The three slits of the spiracle are straight and parallel, pointed at the lower end, below which is the large round button. The pit is located largely below the horizontal bisecting plane, the anal opening being outside of and below the pit. Thompson noted that the puparium of signatus lacks the anal pit, an unexpected aberration verified by the writer in North American specimens in the National Museum.

\footnotetext{
4An. Ent. Soc. Amer., vol. 4, p. 130, 1911.

s Recherches sur les Diptères parasites, p. 112, 1921.

${ }^{6}$ Proc. U. S. Nat. Mus., vol. 60, p. 12, fig. 8, 1921.
} 
Pachyophthalmus is represented by a limited number of species occurring in Europe and the American continents. The adults apparently do not frequent barren sand and denuded ground. They are attracted to flowers, bask on shrubby foliage in the sunlight, and have been noted about habitations, as would be expected from the peculiar host relationships. The members of the genus, so far as known, are biologically superimposed on wasps which build mud nests under shelter or in hollow stems, including members of the families Sphecidae and Eumenidae. The manner in which the female establishes her progeny and the subsequent larval development have not been observed. Rau found the puparia of one species lodged in a hollow stem containing the nests of Odynerus. When associated with the common "dirt daubers" Pelopaeus and Trypoxylon, which build their nests indoors, it is not known whether the maggots pupate within the mud cells of their hosts or leave them to seek other shelter for the transitional stage. The members of the genus Pachyophthalmus are more distinctly aerial in habit than the other North American genera of Miltogrammini. So far as is known, all of the activities of adult, larval, and pupal stages take place in a stratum extending from a foot or more to several feet above the ground. This is a noteworthy biological specialization in a group of flies, most of which pass the immature stages under ground, and never rise, as adults, but a few inches above the ground.

KEY TO NORTH AMERICAN SPECIES OF PACHYOPHTHALMUS

1. Thoracic vittae not continuous over scutellum; hind tibia on outside with a complete row of bristles extending to the apex; the fourth abdominal and

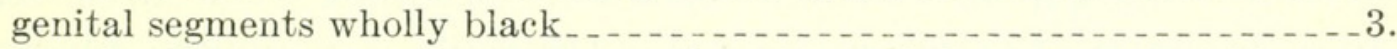

Thoracic vittae continuous over scutellum; hind tibia on outside with a row of bristles not extending far beyond the middle................... 2 .

2. Fourth abdominal segment and genital segments wholly black; parafrontals outside the two frontal rows conspicuously setulose . ..... hinei, new species.

Fourth abdominal segment and genital segments yellow; parafrontals outside the two frontal rows, at most with scattered microscopic bristly hairs

floridensis Townsend.

3. Anterior clasper of the male genitalia much shorter than the penis, and with

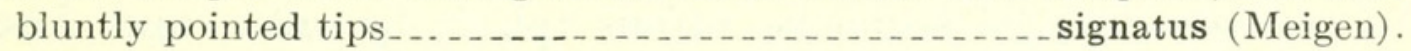

Anterior clasper of the male genitalia nearly as long as the penis, and with exceedingly sharp, delicate, incurved hooks at the tip.

distortus, new species.

UNRECOGNIZED SPECIES OF PACHYOPHTHALMUS

erythrura VAN Der Wulp, Biol. Cent.-Amer., Dipt., vol. 2, p. 89, 1890. Described from a single male from Presidio, Mexico, and assigned to Miltogramma. Type in British Museum.

sarcophagina VAN DER Wulp, Biol. Cent.-Amer., Dipt., vol. 2, p. 90, 1890.

Described from a female from Atoyac, Vera Cruz, Mexico, and assigned to Miltogramma. The type and one other specimen in British Museum.

$54292-26 \dagger-2$ 
PACHYOPHTHALMUS FLORIDENSIS Townsend

Pachyophthalmus floridensis Townsend, Ent. News, vol. 3, p. 80, 1892; An. Ent. Soc. Amer., vol. 4, p. 130, 1911.-Coquillett, U. S. Bur. of Ent., Tech. Ser., No. 7, p. 80, 1897.-Smith, Ins. of New Jersey, p. 778, 1909.Aldrich, Cat. of N. A. Dipt., p. 447, 1905.-Johnson, Bull. Amer. Mus. Nat. Hist., vol. 32, art. 3, p. 72, 1913.-Walton, Proc. U. S. Nat. Mus., vol. 48, p. 182, 1914.-Reinhard, Ent. News, vol. 30, p. 283, 1919.-Cole and Lovett, Proc. Cal. Acad. Sciences, vol. 11, p. 301, 1921.

Sarcomacronychia unica Townsend, Trans. Amer. Ent. Soc., vol. 19, p. 101, 1892.

Sarcomacronychia sarcophagoides Townsend, Canad. Ent., vol. 24, p. 165, 1892.

Sarcomacronychia trypoxylonis Townsend, Bull. Ohio Exp. Sta., Tech. Ser., 1, p. 165.

Sarcomacronychia trivitatta Townsend, Proc. U. S. Nat. Mus., vol. 43, p. 363, 1912, type from Peru deposited in U. S. National Museum, examined by me.-RAU and RAU, Wasp Studies Afield, p. 331, 1916.

Male.-Front at narrowest point 0.25 of extreme width of head (measurements of five as follows: $0.22,0.23,0.24,0.27,0.27$ ); frontal vitta narrowest near middle, where it is one-half to three-fifths width of parafrontals; parafrontals silvery pollinose, outside the frontal rows bare or with sparse microscopic bristly hairs; vibrissae the length of the second antennal joint above front edge of oral margin; facial ridges bristly on lowest half; third antennal joint one and one-half times length of second; arista thickened on basal fourth; penultimate joint slightly longer than broad; proboscis almost equals the head height; labella small and laterally compressed; palpi black. Thorax with the usual three black vittae, extending over the scutellum; three postsutural dorsocentral bristles; scutellum with three nearly equal marginal bristles and small preapicals. Abdomen black excepting the last segment which is red; the three posterior segments thinly gray pollinose, usually to the apex; the intermediate segments with three large, more or less rectangular black spots; first segment bearing strong median marginal bristles; second with median marginals and several lateral bristles, which become weaker as they approach the median line; third and fourth with a marginal row of eight to twelve. Genital segments rufous (pl. 2, fig. 12); inner forceps nearly straight when viewed from the side; outer forceps pale yellow, much less massive than the inner pair, apical two-thirds slender and rounded in cross section; penis with a black, laterally compressed, heavily chitinized hood, consisting of a large, irregular anterior process and a small slender posterior process connected by a narrow translucent membrane; anterior claspers much shorter than the penis, tapering forward to a strong blunt point. Wings with one or two small bristly hairs near the base of the third vein; penultimate section of the fourth vein equaling one-half the preceding section. Pulvilli longer than last tarsal joint; hind tibia on the outside, with an incom- 
plete irregular row, of which the lowest is the largest and is located slightly beyond the middle.

Female.-Front at narrowest point 0.19 of head width (measurements of six as follows: $0.14,0.18,0.18,0.19,0.22,0.23)$. With the usual sexual differences in the genitalia and length of pulvilli. Otherwise like the male.

Length, 5 to $9 \mathrm{~mm}$.

Redescribed from a long series including both males and females, from the following localities: Lafayette, Indiana; Blue Ridge Summit, Pennsylvania; Clementon, New Jersey; Chesapeake Beach and Plummer Island, Maryland; Rock Creek Park, District of Columbia; Potomac Creek, Virginia; Wilmington County, Georgia; Miami and Lake Worth, Florida; Victoria, Waco, and Brownsville, Texas; Colorado; Minot, North Dakota; Moscow, Idaho; Emigration Canyon, Utah; Rio Aravaipa, East Verde River and Cave Creek Canyon, Chiricahua Mountains, Arizona; Socoro, New Mexico; Santa Cruz Mountains, Santa Clara County, Los Angeles County, and Claremont, California; Kaslo, British Columbia; Porto Bello, Panama; Boracoa, Cuba; specimens from Lafayette, Indiana, labelled "on parsnip flower," (J. M. Aldrich); "from cells of P. cementarius" Dorchester County, Maryland, (H. S. Barber); "from nest of P. cementarius," Biloxi, Mississippi; "from the nest of harrisi" (F. M. Jones); "from the nest of wasp Sceliphron cementarium Dr. var."; Toboga Island, Panama, (J. Zetek); all the above in the collection of the United States National Museum. Baldwin, Kansas; Columbus, Ohio; in collection of Prof. J. S. Hine. Agricultural and Mechanical College, Sellers, and Ocean Springs, Mississippi, in my collection.

The conclusions of Aldrich ${ }^{7}$ who examined the types, and of Coquillett ${ }^{8}$ as to the identity of Townsend's (sarcophagoides) (trypoxylonis) (unica) and floridensis has been accepted without further study of the types. Major Austen of the British Museum, who has compared a specimen of floridensis determined by me with the type of (Miltogramma) erythrura Van der Wulp, states that the latter is a Pachyophthalmus but questions whether it is identical with floridensis. He adds that "your specimen is little more than half the size of the type, but in spite of this, and the fact that your specimen is a female, while the type is a male, the enlarged facets in the eyes of your specimen are somewhat larger than the corresponding facets in the eyes of the type. Again, the frontal stripe is black in your specimen, but russet in the type in which the black markings on the first three abdominal tergites are less extensive and less clearly defined than in the specimens forwarded by you." I find that in floridensis, the size, color, and distribution of pollen are characters variable to a 
considerable degree, and that the females possess distinctly larger eye facets than the males, and believe that the differences noted by Major Austen may not be of specific significance. Miltogramma sarcophagina Van der Wulp, according to Major Austen, who has recently examined the type for me, is certainly a Pachyophthalmus. According to the original description, it has a red-tipped abdomen, a character not possessed by any other species of Pachyophthalmus known to me, except floridensis. It seems possible that floridensis is identical with erythrura or sarcophagina of Van der Wulp, or with both, but I hesitate to submerge floridensis in synonomy until after a more careful comparison of types.

PACHYOPHTHALMUS HINEI, new species

Male.-Front at narrowest 0.27 of head width, (measurements of five as follows: $0.26,0.26,0.27,0.27,0.28)$; face and front white pollinose, becoming leaden towards vertex; frontal vitta red, sometimes black, narrowest in front of middle, where it is from less than half to two-thirds as wide as either parafrontal; about 12 bristles in the inside frontal row; parafrontals outside the second frontal row, and as far as base of the antennae, black setulose; vibrissae inserted slightly less than length of second antennal joint above front edge of oral margin; facial ridges with scattered bristly hairs on slightly more than lowest half; antennae black, third joint scarcely longer than second; arista thickened on basal two-fifths, penultimate joint conspicuous and nearly twice as long as wide; parafacials bare; in profile, width of bucca equals width of parafacial and one-eighth eye height; palpi black. Thorax gray pollinose, with three broad black vittae continuous over the scutellum; two, and sometimes three, postsutural dorsocentral bristles; three nearly equal marginal scutellars; no preapicals. Abdomen black, strongly tinged with bronze, densely overlaid with gray pollen, with an obscure, broad, black, median vitta; first segment without median marginal bristles, second with a median marginal pair, third and fourth with uninterrupted marginal rows. Genitalia black, small and fully concealed within the abdomen, in repose; first genital segment without apical macrocahetae; claws of inner forceps nearly straight in profile and terminating in blunt, laterally compressed tips; outer forceps as long and massive as the inner pair, tapering moderately to broad, rounded, polished black tips; penis with the hood largely membranous, consisting of a slender, heavily chitinized stem which extends to apex and supports a posterior, laterally compressed membranous wing which gives to the hood a lanceolate appearance. Wings hyaline; third vein with one to two small bristles at its base. Legs black; pulvilli of fore feet almost as long as last tarsal joint; hind tibia on outside with a row of about eight unequal bristles not extending far beyond the middle. 
Female.-Front at narrowest, 0.25 of head width, in the single specimen measured. Pulvilli of fore feet less than one-half length of last tarsal joint. Otherwise, save for usual differences of genitalia, like the male.

\section{Length, 6 to $8 \mathrm{~mm}$.}

Type.-Male, in the collection of Prof. J. S. Hine, from Cameron, La. August 14-28, 1903.

Allotype.-Female, in the collection of Professor Hine, same locality and date as the type.

Host relationships.-Unknown.

Described from two males and one female from Cameron, La., August 14-28, 1903, and three males from the same locality, July 7 , 1905, all collected by Professor Hine, in whose honor the species is named.

The species is closely allied to floridensis, from which it may be distinguished by the absence of red on the last abdominal segment and the genitalia, the absence of preapical scutellars and median marginal bristles on the first abdominal segment, and in having the parafrontals setulose outside the frontal rows.

\section{PACHYOPHTHALMUS SIGNATUS (Meigen)}

Tachina signatus Meigen, Syst. Beschr., vol. 4, p. 303, 1824.

Tachina anomalus ZetTerstedT, Dipt. Seand., vol. 13, p. 6074, 1859.

Macronychia signata Schiner, Faun. Aust., vol. 1, p. 502, 1862.

Pachyophthalmus signatus Brauer and Bergenstamm, Denkschr. Akad. Wien., vol. 56, pl. 7, fig. 145, 1889; vol. 61, p. 620, 1894-Cocuillett, U. S. Bur. Ent., Tech. Ser., No. 7, p. 79, 1897.-Stein, Entom. Nachricht, vol. 26, p. 149, 1900.-Villeneuve, Bull. Soc. entom. France, 1900, p. 381.-Bezzi and Stern, Kat. Pal. Dipt., vol. 3, p. 518, 1907.-Smith, Ins. New Jersey, p. 778, 1909.-Brimley, Ent. News, vol. 33, p. 24, 1922.

Pachyophthalmus aurifrons Townsend, Trans. Amer. Ent. Soc., vol. 18, p. 354, 1891.

Miltogramma signata PAndellé, Rev. entom., vol. 14, p. 298, 1895.

For this species the writer has accepted the synonomy of Coquillett and Bezzi and Stein without examination of the types concerned. The identity of the European with the North American form has been verified by a comparison of the genitalia.

Male.-Front at narrowest 0.215 of the head width (measurements of four as follows: $0.21,0.21,0.21,0.23)$; frontal vitta dull black, narrowest at base of antennae; at the middle of front, almost as wide as either parafrontal; inner frontal row of about thirteen bristles; parafrontals golden pollinose; vibrissae two-thirds length of second antennal joint above front edge of oral margin; facial ridges irregularly bristly on lower half or less; antennae black, third joint slightly longer than second; arista thickened on basal third; in profile, buccal width equals parafacials and one-sixth the eye height; front projects about one-fourth the eye diameter; proboscis slender, almost equaling 
head height; labella rather small; palpi black. Thorax with the usual three broad black vittae extending as far as scutellum, the latter shining black, without vittae. Abdomen black, with the last three segments thinly gray pollinose, often to their apices; intermediate segments each with three large black spots; strong median marginal bristles on the first two segments, marginal rows of about eight on the last two. Genital segments black; inner forceps (pl. 3, fig. 13) curved forward, tips laterally compressed; outer forceps yellow, tapering to points round in cross section, more slender than inner forceps; penis with black, heavily chitinized hood, bootlike in appearance, with the toe of the "boot" pointed towards the inner forceps and with a transparent keel on its posterior border; anterior clasper slightly more than half as long as penis, tapering to a stout, anteriorly directed point. Wings with two to three small hairs at base of third vein. Legs black; hind tibia with a complete row of uneven bristles on the outside surface.

Female.-Not distinguished with certainty from females of $P$. distortus. The front at narrowest, in five specimens averaged 0.18 of the head width (measurements as follows: $0.15,0.16,0.17,0.22,0.22$ ). Usual sexual differences in genitalia and in length of claws and pulvilli. Otherwise like the male.

Length, 6 to $7 \mathrm{~mm}$.

Redescribed from the following males: One from Holyoke, Massachusetts, no. 1478c Dimmock's Ent. Notes; three from Washington, District of Columbia, one labeled "from wasp's nest" (H. G. Dyer); one labeled "from butter wasp" (C. V. Riley); four from Lafayette, Indiana (J. M. Aldrich); two from Tennessee Pass, Colo. (J. M. Aldrich); three from White Mountains, New Mexico, two labeled "flowers of Cicuta occidentalis" and the other "flowers of Solidago trinervata" (C. H. T. Townsend); two from Mono Lake, California (J. M. Aldrich); two from Sierra Madra, Chihuahua, Mex. (C. H. T. Townsend); all in the collection of the National Museum. One from Sugar Grove, Ohio, and another from Columbus, Ohio, labeled "parasite of Trypoxylon politum," both in collection of Prof. J. S. Hine. One male, Macerat, Italy (?), determined by Professor Bezzi, and one male, Rambouillet, France. Both European specimens in which the genitalia was relaxed were found to be identical with North American material.

Owing to the inclusion of two distinct species under the name signatus, published records referring to this species up to the present should not be accepted without verification. P. signatus occurs in Europe and is also generally distributed over North America, having been identified by the writer from males with the genitalia relaxed, from Massachusetts, District of Columbia, Indiana, Colorado, New Mexico, California, and Chihuahua, Mexico. It is attracted to 
flowers, Townsend having taken specimens in the Southwest on Cicuta occidentalis and Solidago trinervata. The writer on one occasion, captured several specimens basking on sunlit foliage of shrubs and small trees in Massachusetts. I have examined one specimen bearing a record of rearing from Trypoxylon politum Say. The host relationships indicated by Coquillett, ${ }^{9}$ Brimley, ${ }^{10}$ and Malyser ${ }^{11}$ are possibly correct but should be verified.

PACHYOPHTHALMUS DISTORTUS, new species

Male.-Front at narrowest 0.22 of head width (measurements of five as follows: $0.20,0.21,0.21,0.23,0.24)$; frontal vitta black, narrowest near the middle, where it is about two-thirds width of parafrontal, diverging slightly to vertex; parafrontals with a dense inner row of about fifteen bristles, outside of which is a row of smaller bristles and sparse, scattered hairs; vibrissae about halt length of second antennal joint above tront edge of oral margin; antennae black, extending two-thirds distance to vibrissae, third joint slightly longer than second; arista thickened on basal third; penultimate joint nearly twice as long as wide; facial ridges with scattered hairs on lower half; in profile, bucca wider than parafacials and equal to about one-sixth the eye height; front projects about one-fourth eye diameter; parafacials bare save for a few sparse hairs; proboscis about two-thirds head height, stout; labella fleshy; palpi black. Thorax gray pollinose, with the usual three broad black vittae extending as far as the scutellum; three, or sometimes four postsutral dorsocentral bristles; scutellum with three marginals, of which the intermediate pair is larger than the other equal pairs. Abdomen black, densely gray pollinose to apices of segments with three large, shining, irregular black spots on each of the last three segments; first and second with strong median marginal pair of bristles and a few laterals becoming weaker towards the median line; third and fourth segments with marginal row of fourteen to sixteen bristles. Genitalia (pl. 3, fig. 14) black; inner forceps slightly divergent from their base; claws moderately flattened laterally, in profile curved abruptly forward near the tip; outer forceps tapering uniformly to rounded tips about equal to size of tips of inner forceps; penis laterally compressed, with the rolled edges of apical aperture much narrower than width of penis in the middle; anterior claspers nearly as long as the penis, extremely crooked, with very fine hooked tips, best seen from the rear. Wings of usual venation; third vein with two to three small hairs at its base. Legs black; hind tibia with complete row of about nine irregular bristles on outer surface. 
Length, 5 to $8 \mathrm{~mm}$.

Type.-Male, Cat. No. 28150, U.S.N.M., from Stone Valley, Pennsylvania.

Described from the following material, all males: In the National Museum; one from White Mountains, New Hampshire (Morrison); four from Stone Valley, Pennsylvania, June 24 (H. E. Ewing); seven from Plummer Island, Maryland, bred from nest of Trypoxylon potitum, February 25, 1917 (H. L. Viereck); one from Kaslo, British Columbia (R. P. Currie): in the Canadian National collection, two, Barber D., New Brunswick, 24-vi-1914 (F. M. McKenzie) (J. D. Tothill); one, Barber D., New Brunswick, 25-vi-1914 (J. D. Tothill); one, Hamilton River, Muskrat Falls, Labrador, 12-19-vii1919 (S. E. Arthur): in the collection of R. C. Shannon, one from Ithaca, New York, May 25, 1922.

The female, I have been unable to distinguish from those of $P$. signatus. The male also resembles signatus excepting in the genitalia which is widely different. $P$. distortus is at present known from only a limited number of localities in the northeastern states, eastern Canada, and from Kaslo, British Columbia. It has never been collected on flowers. Doctor Ewing secured several specimens from a large number observed flying about the porch of a deserted cabin in Pennsylvania. It has been reared from Trypoxylon politum Say.

\section{Genus SENOTAINIA Macquart}

Senotainia Macquart, Dipt. Exot. Suppl., vol. 1, p. 167, 1846. Genotype, rubriventris from Galveston, Tex., not seen; but the original description mentions the presence of a frontal row of eight bristles, three orbitals, a linear frontal vitta and red abdomen, distinctive of one common North American species widely recognized as rubriventris.-CoquILlett, U. S. Bur. Ent., Tech. Ser., No. 7, p. 80, 1897; Proc. U. S. Nat. Mus., vol. 37, p. 605 , 1910.-Adams, in Williston's Diptera of N. A., p. 373, fig. 152, no. 110, p. 375, (Miltogramma), 1908.-Townsend, Smithson. Mise. Coll., vol. 51, p. 56, 1908; An. Ent. Soc. Amer., vol. 4, p. 140, 1911.

Megaera Robinead-Desvoidy, Myod., p. 94, 1830. According to Bezzi and Stein, (Pal. Dipt., vol. 3, p. 515) preoccupied by Wagler for Reptilia, in August 1830, (Isis, 1830, p. 944). No date other than 1830 appears in Desvoidy's publication.

Sphecapata Rondani, Dipt. Ital. Prod., vol. 3, p. 221, 1859. Genotype not designated by Rondani. S. albifrons Rondani designated by Brauer and Bergenstamm, Denkschr. Akad. Wien., vol. 56, p. 115, 1889. S. conica Fallén designated by Brauer, Vorarb. Monog. Musc. Schizo., p. 58, 1893. But since albifrons equals conica, (Bezzi and Stein, Kat. Pal. Dipt., vol. 3, p. 515) the latter becomes the genotype. After careful examination of European specimens of conica determined by Professor Bezzi and others, I am unable to distinguish any characters of generic importance separating this species from Senotainia.

Misellia Robineau-Desvoidy, Dipt. Env. Paris, vol. 2, p. 146, 1863. Genotype designated is Megaera dira Robineau-Desvoidy which according to Desvoidy's own statement equals Miltogramma conica Fallén. But 
conica belongs to Sphecapata of which it is the genotype, which equals Senotainia, an earlier name. Hence Misellia equals Senotainia.

Euselenomyia Townsend, Proc. U. S. Nat. Mus., vol. 43, p. 364, 1912. Genotype, peruviensis examined by the writer.

Microsenotainia Townsend, Proc. U. S. Nat. Mus., vol. 49, p. 618, 1915. Genotype, Senotainia nana Coquillett, examined by the writer.

Eusenotainia Townsend, Proc. Biol. Soc. Wash., vol. 28, p. 22, 1915. Genotype, Hilarella rufiventris Coquillett, examined by the writer.

Frontal vitta at most slightly wider than parafrontals; proclinate ocellar bristles present; a single row of frontals not descending below base of antennae and not suddenly divergent below; from two to several pairs of orbital bristles present in both sexes; front slightly narrower in females than in males; arista stubby, penultimate joint at most scarcely twice as long as wide; vibrissae differentiated from other hairs about the mouth; facial ridges without macrochaetae, bristly on not more than lowest fourth; parafacials hairy or not, but never with macrochaetae on lowest half; in profile, head length at vibrissae nearly or quite equals that at base of antennae; proboseis slender, and nearly as long as head height; facets at extreme front several times larger than those at sides of eye; bucca and back of head without pale hairs. Convex, posterior part of sternopleuron triangular in outline; two similar, brush like flaps of hairs close the mesothoracic spiracle, the hind flap not differentiated in the shape of a conspicuous oval plume. Male genitalia (pl. 2 figs. $7,8,9,10,11$ ) in repose usually protruding somewhat conspicuously from tip of abdomen; penis with membranous spiniferous hood, frequently saclike and collapsible; posterior clasper with a prominent bristle; female genitalia in the form of non-piercing larvipositors telescoped in the abdomen, in repose. Wings (pl. 4, fig. 24) hyaline; apical cell open; last section of fifth vein distinctly less than half the preceding section; veins without bristles save for one to several small ones at base of third vein. Pulvilli of male nearly or quite as long as last tarsal joint and much longer than those of female.

The female reproductive organs of three species have been dissected (pl. 4, figs. 20, 22, 25). In all, the uterus was found to be very short, with a conspicuous pouch-like expansion, containing, in mature specimens, large active larvae. Considerable aifference in conformation of the various organs of reproduction was noted in the species dissected but this may have been due more largely to variation of stage of maturity than to specific differences.

First instar maggots of four species have been examined. In all, the cuticle is of about the same texture dorsally and ventrally, and is drawn into flat, longitudinal ribs or corrugations on the posterior two-thirds of each segment. The anterior third of each segment is armed with flat, minute scales, not strongly chitinized and scarcely visible except under a high power objective. The maggots are 
metapneustic. The buccopharyngeal apparatus (pl. 5, figs. 30, 31, $32,33)$ is moderately strong, the mouth hooks being much shorter and less massive than the basal piece. The median hook is heavily chitinized; the lateral hooks are not fused at the tip with the median hook, but terminate in well defined tips, similar to the tip of the median hook, in outline, but much less strongly chitinized. The median hook articulates with a slender intermediate region which is in turn firmly fused to the basal piece. The sides of the intermediate region are joined ventrally by a sclerite, which in lateral view appears barblike, and which viewed from above gives the region an $\mathrm{H}$-like appearance. The large basal piece consists of a single ventral and two dorsal wings which are not cleft on their posterior margins. This agrees in every particular with Thompson's description of the first instar maggot of Sphecapata conica..$^{12}$

$S$. trilineata is the only species in which the second instar maggot has been studied. The body is white, with transparent cuticle through which the internal organs are plainly visible. The cuticle of the first four segments bears irregular rows of minute black spines confined to an encircling belt on the anterior third of the segment. In this instar, the maggot is amphipneustic, the anterior spiracle terminating in several fingerlike papillae spread fanlike and protruding conspicuously from the body. The buccopharyngeal apparatus differs from that of the first instar maggot in several particulars (pl. 5, fig. 34). There are two strong lateral hooks but no median hook; the intermediate piece articulates freely with the basal piece as well as the bucal hooks; the superior wing of the basal piece has at its posterior margin, two prolongations separated by a deep cleft; and dorsal to the intermediate region is a weak vestigial sclerite called the dorsal accessory piece.

The puparia of three species have been studied (pl. 4, fig. 21). They are characterized as follows: Yellowish to chestnut-brown in color, rather smooth and thin-walled; with minute brown spines on the anterior third or less of the segment, spiniferous areas encircling the segments anteriorly, limited to the ventral surface posteriorly; round in cross section; from the lateral aspect, oval save for the extreme posterior margin which is truncate. Anterior spiracle protruding, terminating in several fingerlike papillae, radiating fanlike from the base; posterior spiracles located in distinct shield-shaped pit (pl. 5, fig. 27), centered on the longitudinal axis; spiracles located at the upper part of the pit, separated by at least their diameter, broadly rounded above, tapering to a point below; button indistinct; anal opening large and located at some distance below the pit.

Several species of this genus are widely distributed over North America, at least one of which occurs as far southward as Peru, in 
South America. Other species (Sphecapata) are widely distributed over Europe. So far as known, the European and New World forms are distinct. In North America the genus ranges from British Columbia and Ontario on the north, to Panama, and is represented also in some of the West Indian islands. This genus appears to be best represented in the fauna of the south and southwestern states, where as many as six species may be present in the same general locality. Northward the number diminishes, and southward in tropical America, also, fewer species are known, though perhaps because that region has been less thoroughly worked. Judging from its presence in collections, the individuals of the genus Senotainia are nearly if not quite as abundant as individuals of all other Mittogramminid genera combined. In the collection of the writer which is largely from Mississippi and Ohio, over seventy per cent of all Miltogramminae are Senotainia, and Metopia, with about seventeen per cent, is the genus which most closely approaches it in numbers. A somewhat similar ratio exists in the other large collections studied.

The adults of several species of Senotainia are attracted to flowers. Several species of flowers may be visited by one species of fly. Compositae appear to be favored, but the blossoms of other groups are also visited. The writer has never taken them on the blossoms or foliage of trees or high shrubs. It has been noted that in species of Senotainia that visit flowers, the proboscis is long and slender, while in Metopia, Sphenometopa, Phrosinella, and other genera in which the adults have never been taken on flowers, the proboscis is veryishort and stout.

The members of the genus Senotainia, so far as known, are biologically superimposed on fossorial Hymenoptera, principally as commensals living on the food provided by the wasps for their young, frequently eliminating the grub of the wasp either by producing unsuitable conditions or by direct predatory act, but probably never as a true endoparasite of the latter. The females deposit large, active, naked larvae, probably in most cases, on or near the paralyzed prey of Hymenopteron hosts, after it has been placed in the burrow. The members of at least three families of Aculeata, Bembicidae, Psammocharidae and probably Sphecidae are attacked by Senotainia. All so attacked dig burrows in the soil, some of which are provisioned with spiders, others with flies, Heteropteron nymphs, or other Arthropod prey. From the rather limited rearing records, it would appear that the larvae of Senotainia are far less exacting in their food requirements than typical Tachinids, in this respect much more closely approaching the typical Sarcophagidae and Calliphoridae. The conjectures of Townsend ${ }^{13}$ as to the larval habits of

${ }^{13}$ An. Ent. Soc., vol. 4, p. 140, 1911. 
Senotainia have been largely disproved by actual observations on the larvae of several species, recorded elsewhere in this paper.

The habit of trailing or "shadowing" the host as it carries the prey to its nest seems to be more highly developed in this genus than in any other in the group. This habit appears related to two structural characters not occuring in such a pronounced degree in other North American Miltogrammini, excepting in the genus Pachyophthalmus, which are, namely, the conspicuously enlarged facets of the front part of the eyes, and the uniformly narrower front and larger development of the eyes in the female as compared with the male. The possession of larger eyes with the enlarged facets, should in all probability be regarded as specializations permitting the female to keep herself oriented more readily with the rapidly moving form of the wasp she follows, while in flight.

So far as observed, the members of this genus display little or no interest in burrows stocked with food, or the paralyzed victims of the wasp, when it drops them outside its burrow, but is strongly excited by the presence of the wasp carrying its prey, and is seemingly stimulated to larviposition only in the presence of this combination.

KEY TO NORTH AMERICAN SPECIES OF SENOTANINIA

1. Sternopleura with one bristle _.

Sternopleura with two bristles_._.

2. Abdomen red, at least on the sides; third antennal joint red or at most with blackish tomentum over the red . . . . . .

Abdomen wholly black . . .

3. The two frontal rows of macrochaetae, at their middle, separated by a distance greater than width of either parafrontal; three distinct postsutural dorsocentral bristles trilineata Van der Wulp.

The two frontal rows of macrochaetae, at their middle, separated by a distance less than width of either parafrontal; not more than two postsutural dorsocentrals differentiated ............................. litoralis Allen.

4. Second abdominal segment with median marginal bristles _..._. _ _ _ _ _ 6 .

Second abdominal segment without median marginal bristles_....._._. _ 5 .

5. Arista thickened almost to the tip; third antennal joint at least nearly three times length of second joint rufiventris (Coquillett).

Arista thickened on basal half; third antennal joint at most scarcely exceeding two times length of second joint _........... flavicornis (Townsend).

6. Arista thickened on the basal two-fifths; bucca in profile usually not more than one-twentieth the eye height; two proclinate orbital bristles; outer forceps of male genitalia with a strong rounded hook, directed anteriorly.

rubriventris Macquart.

Arista thickened on basal three-fifths; bucca in profile at least one-tenth eye height; usually but one proclinate orbital bristle; outer forceps of male genitalia with stout, sharp tip posteriorly directed and apposed to the tip

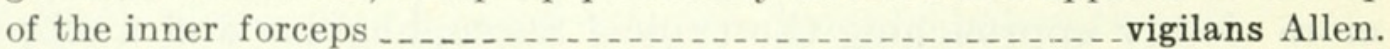

7. Costa, near the humeral angle, with erect, radiating, bristly hairs; inner forceps of male genitalia broadly triangular when viewed from behind.

setulicosta, new species. 
Costa, near the humeral angle, with appressed hairs; inner forceps of male genitalia elongate and linear when viewed from behind_..._nana Coquillett.

UNRECOGNIZED SPECIES AND OTHERS MENTIONED BY ALDRICH ${ }^{14}$ AND BY COQUILLETT ${ }^{15}$

biseta Thomson, Kong. Sven. Freg. Eugenies Resa, p. 524, 1868. There is no record of this species since the type was described from Panama in 1868. From the description is seems probable that the species belongs in Senotainia, but its exact position is rather uncertain.

erythrocera Thomson, Kong. Sven. Freg. Eugenies Resa, p. 523, 1868. This species from California is described as possessing a long, pale, shaggy beard, three sternopleural bristles and discal bristles on the fourth abdominal segment-characters sufficient to place it outside the limits of Senotainia, and in all probability outside the subfamily Miltogramminae.

sarcophagina VAN DER Wulp, Biol. Cent. Amer., Dipt., vol. 2, p. 90, 1890.

Major Austen reexamined the type in the British Museum for me, finding that the specimen possessed two rows of frontal bristles on each side of the frontal vitta. He writes that it is certainly a Pachyophthalmus, to which genus it has been assigned.

erythrura VAN DER Wulp, Biol. Cent. Amer., Dipt., vol. 2, p. 89, 1890. Major Austen, who has examined the type in the British Museum for me states that this species is also a Pachyophthalmus, to which genus it has been assigned.

fulvicornis VAN der Wulup, Biol. Cent. Amer., Dipt., vol. 2, p. 89, 1890. Described from type and one other female from Guerrero, Mexico, and assigned to Miltogramma. Type in British Museum reexamined for me by Mr. Barnett who states that "the type does not possess a pair of marginal bristles at the apex of the second abdominal segment; the tibia of the hind leg is equipped with a more or less complete row of bristles on the outside; there are more than ten bristles in the frontal row on either side of the frontal vitta; the eyes are nearly twice as high as wide." These characters serve amply to distinguish it from rubriventris with which it has been considered synonymous. Major Austen states that it is a Sphixapata, which equals Senotainia. He has compared the type with a specimen of Senotainia flavicornis Townsend determined by me which possesses all the characters listed above for the type of fulvicornis, and states that they are certainly not conspecific. It does not appear to be identical with any other species discussed in this paper and must represent a distinct species which I am at present unable to place.

nana VAN DER WULP, Tijdschr. v. Ent., vol. 35, p. 195, 1888; Biol. Cent. Amer., Dipt., vol. 2, p. 483, 1903 . Described and assigned to Miltogramma; type, a female from Guerrero, Mexico, has been lost. I find it impossible to definitely determine the place of this form from the superficial nature of the description. It has not been reported since its deseription over 35 years ago. It may belong to the genus Senotainia, and is most certainly distinct from nana Coquillet and other species of the genus mentioned in this paper. Unless the type should be found, the name might best be disregarded.

fasciata Coquillett, U. S. Bur. Ent., Tech. Ser., No. 7, p. 81, 1897 . Equals Eumacronychia elita Townsend. 
Miltogramma flavicornis Townsend, Trans. Amer. Ent. Soc., vol. 18, p. 355, 1891. Type from southern Illinois.

Miltogramma similis Townsend, Trans Amer. Ent. Soc., vol. 18, p. 357. Miltogramma kansensis Townsend, Can. Ent., vol. 24, p. 68, 1892.

Male.-Front at narrowest 0.25 of the head width (measurements of five $0.24,0.24,0.24,0.25,0.28)$; front and face silvery pollinose; vitta brownish, somewhat pollinose, width at base of antennæ not more than twice the diameter of lowest ocellus, widening to slightly more than width of parafrontal at ocellar triangle; frontal row with 12 to 18 bristles; with one reclimate and usually two, sometimes one, three or even more proclinate orbital bristles; sparse bristly hairs on parafrontals outside the frontal row; antennae red, third joint two to two and one-half times as long as the second; arista thickened on basal half, penultimate joint almost twice as long as wide; parafacials bare; facial ridges bristly on lowest fifth; bristles frequently scattered rather irregularly over the expansion of the facial ridges lateral to vibrissae; in profile, width of bucca is subequal to parafacials, and equal to one-eighth of eye height; eye height almost twice eye width; palpi nearly filiform, scarcely larger than arista, yellow. Thorax thinly gray pollinose over black, with three narrow median vittae not extending beyond transverse suture; caudad of suture, three broad black vittae; two strong sternopleurals, and two postsutural dorsocentrals of which the anterior one is much the weaker; three pairs of marginal scutellars of about equal size. Abdomen black, usually with a lateral red spot involving the second and frequently the third and fourth segments on their sides, separated dorsally by a black vitta; thinly gray pollinose on the bases and surrounding the black polished apices of the last three segments; no median marginal bristles on the first two segments, a marginal row on each of the last two. The inner forceps of the genitalia (pl. 2, fig. 9) are black with rather long slender tips, slightly thinner onethird the distance back than just before the tips; outer forceps nearly as long and as large as the inner, rather broad, with sharply pointed tips directed anteriorly and not apposed to the tip of inner forceps; posterior clasper bearing a long bristle; penis with a spiniferous, membranous hood terminating in a small pendant cylindrical process. Wings with one to five bristles in a tuft at base of third vein. Legs black; middle tibia with a single bristle on outer front side near middle.

Female.-Front at narrowest 0.22 of head width in the single specimen measured; frontal rows not so thickly beset with bristles; third antennal joint one and one-half times as long as second. Genitalia retracted within abdomen in repose. Claws and pulvilli much shorter than last tarsal joint. Otherwise like the male. 


\section{Length, 4.5 to $11 \mathrm{~mm}$.}

Redescribed from a long series consisting largely of males in the collections of the National Museum, the Museum of Comparative Zoology at Cambridge, Massachusetts, Dr. C. W. Johnson, and the writer from the following localities: Lafayette and Michigan City, Indiana; Algonquin and Carlinsville, Illinois; Maryland; Tifton, Georgia; Georgiana, Florida; West Point and Agricultural and Mechanical College, Mississippi; Kansas; Cambridge, Nebraska; Wild Horse Canyon, Animas, Santa Fe, and Socorro, New Mexico; College Station, Balmorehea, and Galveston, Texas; Powdersville, Montana; Los Angeles County, California; Havana, Cuba; one male, Owen's Lake, California, labeled "on flowers of Asclepias" (J. M. Aldrich); one male in the Loew collection bearing an orange label.

The synonomy for this species has been submitted after a careful study of Townsend's types loaned by the University of Kansas Museum. The number of orbital bristles on the types of simitis and flavicornis is variable, even as between the two sides of the same specimen, varying from one to four. In the typical specimen best represented by kansensis there are one reclinate and two proclinate orbitals.

It is not unusual to find specimens intermediate between typical flavicornis and rubriventris, which can not be very satisfactorily placed. In the typical flavicornis, the eye is more elongate, the frontal row is more thickly beset with bristles, no median marginals occur on the second segment of the abdomen, the hind tibia on the outside is ciliate with a complete row of short bristles interrupted by one long spine in the middle, and the specimens are usually larger in size.

Owing to the confusion that has long existed between this species and rubriventris, our knowledge of the geographical distribution is limited. Specimens have been identified from Maryland, Indiana, Illinois, Georgia, Florida, Mississippi, Kansas, Nebraska, New Mexico, Texas, Montana, California, and Cuba. It has not as yet been identified from the northeastern United States, Canada, or the Central American countries. Nothing is known of the host relationships. The writer found the adults abundant on the blossoms of Erigeron in May in north central Mississippi, associated with S. trilineata. Since then it has been collected occasionally on cowpea foliage in the same locality. Dr. J. M. Aldrich reports collecting it from flowers of Asclepias in California. I have never encountered this species resting on barren soil in the sunlight as do the other common species of the genus. In collections, males far outnumber females, very likely because the normal habitat of the mature female has not yet been discovered. 
Senotainia rubriventris Macquart, Dipt. Exot. Suppl., vol. 1, p. 167, 1846. Type from Galveston, Tex.-Coquilletr, U. S. Bur. Ent., Tech. Ser., No. 7, p. 80, 1897.-Osborn, Ohio Naturalist, vol. 7, p. 38, 1906.Sмiтt, Ins. of New Jersey, p. 778, 1909.-Johnson, Bull. Amer. Mus. Nat. Hist., vol. 32, 1913.-Walton, Proc. U. S. Nat. Mus., vol. 48, p. 182, 1914.-Aldrich, An. Ent. Soc. Amer., vol. 8, p. 82, 1915.-Reinhard, Ent. News, vol. 30, p. 284, 1919.-Brimley, Ent. News, vol. 33, p. 25, 1922 .

Miltogramma decisa Townsend, Ent. News, vol. 3, p. 81, 1892.

Male.-Front at narrowest 0.25 of head width (measurements of four as follows: $0.25,0.25,0.25,0.26)$; frontal vitta brown, at base of antennae scarcely twice width of lowest ocellus, widening to two and one-half times width of parafrontal at ocellar triangle; one reclinate and two proclinate orbital bristles; front nearly destitute of bristly hairs; vibrissae length of second antennal joint above front edge of oral margin, separated by distance equal to one and one-half times second antennal joint; facial ridges bare excepting one or two small bristles above the vibrissae; region lateral to vibrissae without scattered bristly hairs; antennae yellow, extending three-fourths distance to vibrissae; third joint one and one-half to two times as long as the second; arista thickened on basal two-fifths, penultimate joint as broad as long; parafacials bare; palpi yellow; in profile, bucca onetenth to one-twenty-fifth eye height and distinctly narrower than parafacials; eye more than half as wide as high. Thorax gray pollinose over black, with three narrow median vittae; two strong sternopleural bristles present and four postsutural dorsocentrals of which the anterior two are small or absent altogether; scutellum with three pairs of marginals of equal size. Abdomen with intermediate segments and lateral posterior part of first, rufous, the remainder of the first and the fourth black, frequently with a dorsal triangle of black on intermediate segments, last three segments thinly whitish pollinose; second segment bearing a median marginal pair of bristles, third and fourth each with a marginal row of about eight. Genitalia (pl. 2, fig. 8) black, with the appearance, in repose, of being too large to fit into tip of abdomen; inner forceps shining black, moderately short and blunt, with sharp, stout tips, united to apex save for minute apical cleft, in profile, convex on outside, nearly straight inside; outer forceps brown, distinctly shorter than the inner pair, strongly rounded over at the tip into a rather bluntly-pointed hook, directed cephalad like the inner forceps; sides of fifth sternite with angular apex and bearing appressed, bristly black hairs to the tip. Legs black; middle tibia with a single bristle on outside near the middle; hind tibia with a row of four unequal bristles on outside, not extending far beyond middle; hind femur without villosity on inner proximal 
surface. Wings without costal spine; third vein with one to two small bristles at its base.

Female.-Front at narrowest 0.25 of head width (measurements of five as follows: $0.25,0.25,0.25,0.25,0.26)$; otherwise except for usual sexual differences of pulvilli and genitalia, like the male.

Length, 3.5 to $6 \mathrm{~mm}$.

This species is well represented by both males and females in all collections examined by me. Redescribed from a long series of specimens from the following localities: Massachusetts; Button Woods, Rhode Island; Lahaway, Ocean County, Ocean Grove, New Jersey; Chesapeake Beach, Plummer Island, Maryland; Sandusky, Cincinnati, Blackhand, Ohio; Lafayette, Plymouth, Michigan City, Indiana; Raleigh, Laurel Hill, North Carolina; Georgia; Miami, White Sulphur Springs, Florida; Holly Springs, Starkville, McHenry, Ocean Springs, Mississippi; College Station, Texas; Colorado; Socorro, New Mexico; Ormsby County, Nevada; Claremont County, California; Moscow, Julietta, Idaho; Owl Creek Mountains, Wyoming; Umatilla, Oregon; Sea Cliff, Long Island, labeled "on beach and salt grass"; Koebler, New Mexico, labeled "Webster No. 7707," (W. R. Walton); one female labeled "Parker Note No. 18" and another female, "Parker Note No. 27"; one female, reared from nest of Bicyrtes quadrifasciata, Adaton, Mississippi, Aug., 1922, and several males from flowers of Erigeron, Agricultural and Mechanical College, Mississippi (H. W. Allen).

The puparium possesses the following characters: Yellowish-brown in color, with small, backwardly-directed spines encircling the anterior part of the thoracic segments, but limited to ventral parts of addominal segments; anal segment without well-developed spines above the depression; from lateral view, broadest at middle, the dorsal and ventral margins convex; anterior spiracle with six papillae; anal depression moderately deep.

This species has been identified by the writer from many localities ranging from Massachusetts, Idaho, and Oregon on the north, to Florida, Texas, and California, indicating that it is generally distributed throughout continental United States. It has been reported in literature from Canada, certain islands of the West Indies, and Mexico, but it should be remembered that other nearly related species have long been confused with this form, hence such records must necessarily be verified before being accepted.

The published records relating to the biology of this species are few and those we have are open to doubt as to the correctness of determination. Professor Osborn's interesting notes on wasp-trailing flies ${ }^{16}$ probably refer to rubriventris, though they may be referable

\footnotetext{
15 Ohio Naturalist. vol. 7, no. 2, p. 38 .
} 
to other species of the rubriventris group known to be present in the Great Lakes region.

The writer has taken the female in midsummer, on sandy, barren spots in open pasture, and the males in large numbers on the flowers of Erigeron, in early spring. One adult has been reared from nests of Bicyrtes quadrifasciatus stocked with Heteropteron nymphs, from Adaton, Miss. A small maggot was discovered on July 17 boring into a paralyzed nymph in the nest of the wasp taken to laboratory on July 15. By the following day it had dismembered the nymph and bored into the sand beneath to pupate, and on July 28 , the fly emerged. The last part of the larval stage was passed in burrowing in and out of the putrid material, like a typical Sarcophaga maggot.

Prof. J. B. Parker has made some interesting observations on the biology of this species in connection with his work on wasps at Washington, D. C. One female, labeled, "Parker Note No. 18," was captured after invading the burrow of Oxybelus quadrinotatus Say on June 20, 1914. In another observation, "Parker Note No. 27," he states that on June 24, "a solitary wasp was discovered entering her nest with a grasshopper. A fly dashed into the nest after the wasp and was captured as it came out. The nest was opened at once and found to contain three completed brood chambers, and one incompleted. The incompleted brood chamber contained two grasshoppers each of which bore fly larvae." In one of the completed chambers, with the partly-consumed stock of grasshoppers, "was found a single fat dipterous larva which was taken to the laboratory and placed in a breeding cell." On July 12, 1912, the fly emerged. The wasp was not identified.

\section{SENOTAINIA VIGILANS Allen.}

Senotainia vigilans Allen, Occas. Pap. Bost. Soc. Nat. Hist., vol. 5, p. 8y, 1924.

Type.-Male, Cat. No. 27231, U. S. N. M., from Adaton, Miss.

This species closely resembles litoralis Allen from which it differs in having a large amount of red on the abdomen, while the latter is constantly black throughout. In vigilans there is usually but one proclinate orbital (pl. 4, fig. 23) and in the male, the sides of the fifth sternite are lobiform, and the hind femur bears villous hairs equalling the thickness of the femur on the proximal third of the under surface. Some specimens of vigilans vary toward rubriventris. Males of vigitans may be readily distinguished by the tips of the outer forceps (pl. 2, fig. 11) which are angular and hooked towards tip of inner forceps, by the lobiform fifth sternite and the villosity of the hind femur. In both sexes of vigilans, the bucca and front is wider, the arista more extensively thickened than in rubriventris.

Two mature females have been dissected and the reproductive organs examined (pl. 4, fig. 22). The outstanding morphological 
characters are as follows: Spermathecal ducts not united, their basal halves conspicuously inflated; accessory glands of equal size, elongate, more than ten times length of their ducts. In the uterine pouch of one, 15 large maggots were counted. With the maggots in the pouches occurred the larval sheaths, evidently sloughed off by the larvae as soon as they became active in the uterus. The sheath was reticulated, more conspicuously so in a belt about the middle. Uterine maggots in the specimens dissected were all at about the same stage of development.

Several first instar uterine maggots have been examined. In the buccopharyngeal apparatus ( $\mathrm{pl}$. 5, fig. 33) were found the only readily recognized specific characters. The median hook is broad to the middle, thence suddenly constricted to a fine, slightly curved point, ventral tooth lacking; lateral hooks moderately curved but not definitely hooked.

The puparium (pl. 4, fig. 21) is chestnut-brown in color, with minute, backwardly directed spines encircling the anterior part of the first five segments; and occurring ventrally on the remainder of the segments. In lateral view; broadest caudad of the middle, tapering slightly towards the front, abruptly behind; dorsal margin convex, ventral straight or even slightly concave in the middle. Anterior spiracle with four or five papillae. Anal depression as in rubriventris but distinctly deeper than in trilineata.

Specimens have been examined from Massachusetts, Ohio, District of Columbia, Maryland, and Mississippi. In the Canadian national collection there are several specimens from Vernon, British Columbia, Onah and Aweme, Manitoba. The habitat of vigilans appears to be more restricted than that of some of the more common species of the genus. In Mississippi, specimens were taken on the sides of a shady road, in the "flat woods" predominated by short leaf pine in mixture with hardwoods. In Ohio, a puparium was dug from a small sand deposit on a wooded river bank. Adults have not been taken on flowers.

The biology of vigilans is linked with that of two species of Bicyrtes, quadrifasciata from which it has been reared and ventralis Say, from whose burrow the female fly has been captured, and with Bembix spinolae. All three wasps belong to the sand burrowing Bembicidae. Both species of Bicyrtes stock their cells with Hemiptera, while Bembix spinolae provisions its nest with Muscoid flies.

Prof. J. B. Parker in 1914, at Washington, D. C., captured a female emerging from the nest of Bicyrtes ventralis and another female coming out of a burrow of Bembix spinolae. ${ }^{17}$

S. vigilans was also noted in the field during July, 1922 by M. R. Smith who found the flies associated with wasps in a colony of $B$. 
quadrifasciata under observation at Adaton, Mississippi. Several visits were made to this colony during the next few weeks until the extreme dry weather and heavy traffic over the road in which the colony was located obliterated all traces of the wasps. Adults of vigilans were abundant about this colony for several weeks. The fly was frequently observed in low zigzag flight over the sand from which it would alight at frequent intervals on small sticks or blades of grass. Intense interest was displayed by females in Bembecids returning to their nests. While the wasps were in flight about their burrows, the flies were frequently seen hovering cautiously about a foot behind them. The presence of the flies seemed to annoy the wasps, which would frequently turn on them and attempt to drive them away, but such attempts were futile, as the flies, no longer pursued, would immediately return. The fly was seen to dart swiftly into the burrow after the Bembicid, and to emerge again, almost immediately, and before the reappearance of the wasp. After depositing its prey, the wasp would emerge, cover up the entrance to its burrow and fly away. In this connection, it may be noted that quadrifasciata usually closes its burrow each time that it leaves it, a precaution which serves to repel parasitic flies during its absence but very clearly affords no protection against those with a habit like that of vigilans, which enters the burrow during the visits of the wasp. Smith has observed that quadrifasciata does not invariably close its burrow when leaving it, as he has on several occasions unearthed several well stocked cells left conspicuously open. Such nests, while especially vulnerable to attack, do not seem to be sought out by vigilans. It was observed that the wasp, carrying prey, was the principal cause of excitement and activity on the part of the flies and it is quite likely that in this species, this combination is necessary for the stimulation of the female to larviposition.

A number of the nests of quadrifasciata were unearthed and the contents, consisting of the egg of the Bembicid in the midst of Pentatomid and Coreid nymphs, were carefully removed. No evidence of the maggots was found in the field, but in one lot, maggots were unexpectedly encountered a day or two after removing the contents of the cell to the laboratory, and from them the adults of vigilans were reared. The bodies of the nymphs were rapidly reduced by the maggots to a putrid mass in which they reveled like Sarcophagid scavengers in decomposing flesh. In the one completed nest of quadrifasciata from which this parasite was reared, the maggots did not show up until after the egg of the wasp had hatched. Maggots of Senotainia and grub of Bicyrtes were both observed feeding on the provisions of the nest on one day, but on the succeeding day, the grub had succumbed, either to direct onslaught by the maggots or the unfavorable conditions produced by them, but at any rate, not to. 
direct parasitism. At the termination of the feeding period of the maggots, two living nymphs remained still untouched, so it appears in this instance that the competition for food did not furnish the urge for the elimination of the host. So far as could be determined, the somewhat slower growing wasp grub with its more delicately adjusted parasitic life, was overwhelmed in the tumultuous activity of the fly maggots, to whom its death was merely incidental. The maggots, reared during July, developed very rapidly, far outstripping the grubs of Bicyrtes reared in the laboratory under the same conditions. Maggots removed with the nest on July 26, pupated on the 30th, indicating a larval period of approximately four days. In Columbus, Ohio, one specimen was reared from a puparium recovered from damp sand near the underground cells of Bembix spinolae, indicating that the mature maggots at the termination of the feeding period burrow in the soil that surrounds the nest to pupate. The pupal duration of two individuals was respectively seven and eight days. Possessing the power to complete a life cycle in about two weeks, it is highly probable that generations succeed each other rapidly during the favorable seasons. However, the development of but one generation has been under observation and the seasonal cycle is unknown.

\section{SENOTAINIA LITORALIS Allen}

Senotainia litoralis Allen, Oec. Papers Bost. Soc. Nat. Hist., vol. 5, p. 90, 1924

Type.-Male, Cat. No. 27232, U.S.N.M., from Moss Point, Mississippi.

This species may be readily separated from tritineata, from which it differs in having the frontal rows at their middle separated by a distance less than width of either parafrontal and in having but two weak postsutural dorsocentral bristles. From vigilans, it is distinguished by lack of red on the abdomen and usually in the possession of two proclinate orbital bristles. Male specimens differ in having the sides of the fifth sternite roundly angular at the apex and not lobiform, and the hind femur without villosity on the inner proximal surface. The male genitalia are illustrated (pl. 2, fig. 10).

In the one female dissected, the reproductive apparatus (pl. 4, fig. 25) was found to differ from the typical in several respects. Whether these variations are specific or merely individual was not determined. The uterine pouch was balloon-shaped and not chordate; the ovules were filled with ova of all stages of development while at the same time the uterine pouch carried several well developed larvæ. Only two spermathecae were present, and these were united for somewhat more than the basal half. One of the accessory glands was very much reduced in size, the other normal, with the duct less than one-tenth the length of the gland. 
This species has been most frequently encountered on the marine beach from Massachusetts to Louisiana. That it also has a limited distribution inland is indicated by the recovery of specimens at Agricultural and Mechanical College, Mississippi, College Station, Texas, and from Indiana and Idaho. In flight, the adults barely clear the sand over which they glide in a swift zigzag course, so closely resembling that of small burrowing Hymenoptera of the beaches that they can be distinguished with certainty only when they alight, as they do at frequent intervals on the surface of the sand. Large numbers of adults, both males and females, were observed on the blossoms of a common Hydrocotyle of the upper beach, in full bloom along the Gulf coast in early September. The host relationships are not known.

\section{SENOTAINIA NANA Coquillett}

Senotainia nana Coquillett, U. S. Bur. Ent., Tech. Ser., No. 7, p. 80, 1897. Type from Las Cruces, N. M.

Microsenotainia nana Townsend, Proc. U. S. Nat. Mus., vol. 49, p. 618, 1915.

This species is very evidently not the same as Miltogramma nana Van der Wulp. The latter name has priority, but unless the type which has been lost is located and after reexamination is definitely assigned to this genus, it is deemed inadvisable to propose a new name for Coquillett's species. Townsend proposed a new genus to receive this species on characters which in my opinion are of less than generic rank.

Male.-Front at narrowest 0.29 of head width (measurements of three as follows: $0.27,0.30,0.30)$; inner orbits diverge from base of antennae, slightly towards vertex, moderately towards bucca; front and face merging from black at the vertex to silvery pollinose at bucca; frontal vitta yellow, linear, scarcely wider than lowest ocellus, obliterated at ocellar triangle; about seven very weak bristles in each frontal row, the rows separated by a distance equal to half width of parafrontal; parafrontals strongly flattened towards vertex, lacking bristly hairs; one reclinate and two proclinate orbital bristles; vibrissae strongly approximated, inserted length of second antennal joint above oral margin; facial ridges bare; antennae extending three-fourths distance to vibrissae, red, the third joint scarcely twice as long as second; arista thickened on basal twofifths, penultimate joint very short; in profile, axis at vibrissae slightly less than at base of antennae, width of bucca less than that of parafacials and equal to one-sixth of eye height; front projects nearly one-half the eye diameter; parafacials bare, palpi yellow. Thorax, including the scutellum, thinly gray pollinose over black, without spots or distinct vittae; usually one and sometimes two postsutural dorsocentral bristles differentiated; one sternopleural; three pairs of marginal scutellar bristles. Abdomen red, excepting 
apex of fourth segment which is black, in profile, distinctly arched; without macrochaetae, save for the scarcely differentiated marginal pairs on third and fourth segments; last three segments with a thinly pollinose band confined to basal third of the segment. Genitalia black; in repose, exserted for distance about equal to width of fourth abdominal segment; inner forceps elongate, in profile, curved slightly forward to a strong, sharp point, from behind, are seen to be united into a single laterally compressed process, linear like the back of a knife blade. Wing of usual veination, without costal spine or bristles at base of third vein; proximal half of costa with short, appressed, black hairs. Legs black; pulvilli of fore feet longer than last tarsal joint; middle tibia with one bristle on outer front side near middle; hind tibia with but two bristles on outside near the middle.

Length, 3 to $4 \mathrm{~mm}$.

Type.-Male, Cat. No. 3580, U.S.N.M.

Host relationships.-Unknown.

Redescribed from the type and the paratype, labeled "swept from Pectis papposa," Las Cruces, New Mexico (Cockerell), and one male specimen from Los Angeles County, California, all in the National Museum. Female unknown.

\section{SENOTAINIA SETULICOSTA, new species}

Male.-Front at narrowest 0.30 of head width (measurements of two as follows: $0.29,0.31)$; inner orbits converge moderately from vertex to the base of the antennae, thence divergent in a broad curve to the bucca; front golden pollinose; frontal vitta yellow, linear, scarcely the width of ocellus to above the middle, thence diverging rapidly to vertex; frontal rows of about ten weak bristles, separated at their middle by a distance less than one-half width of parafrontal; one reclinate and two proclinate orbital bristles; parafrontals sparsely beset with black bristly hairs; vibrissae strongly approximated, inserted at distance equal to second antennal joint above front edge of oral margin; facial ridges bare save for one or two bristly hairs above the vibrissae; antennae red, extending about two-thirds distance to vibrissae; third joint equal to second; arista thickened on basal two-fifths, penultimate joint very short; parafacials bare; in profile, the buccal width is much less than that of parafacials, and equals one-sixth to one-tenth the eye height; head length at vibrissae equals that at base of antennae; front projects nearly one-half the eye width; palpi yellow. Abdomen strongly arched in profile, red, excepting apex of fourth segment which is black; broad pollinose bands encircle the basal halt of the last three segments; abdomen without macrochaetae save for a weak median marginal pair on the third and fourth segments. Genitalia black; 
in repose exserted conspicuously from the tip of the abdomen; inner forceps elongate, united to tip, in profile the posterior edge straight to the apex, viewed from behind broadly triangular. Wings without a costal spine; costa, on its proximal half, with conspicuous, erect, radiating, bristly hairs; third vein without bristles. Legs black; middle tibia with one bristle on the outer front side near the middle; hind tibia with two to five unequal bristles on the outer surface, not extending far beyond the middle.

Length, 4.5 to $5 \mathrm{~mm}$.

Type.-Male. Cat. No. 28151, U.S.N.M., from Pasadena, California, April, 1915.

Host relationship.-Unknown.

Described from the type and one other male from Santa Clara County, California (Baker). Female not known. These specimens in the National Museum, had been labeled "decisa," but when compared with the type of that species were found to be incorrectly determined. They are evidently the ones examined by Townsend when "subgenus B" of the genus Microsenotainia ${ }^{18}$ was proposed for decisa. Townsend's decisa, however, is without question the same as rubriventris Macquart, and differs widely from the two California specimens described above.

\section{SENOTAINIA TRILINEATA (Van der Wulp)}

Miltogramma trilineata VAN Der Wulp, Biol. Cent.-Amer. Dipt., vol. 2, p. 89, 1890. Type locality, Presidio, Mex.

Arrenopus americanus Brader and Bergenstamm, Denkschr. Akad. Wien., vol. 58, p. 361, 1891 . Type locality, Georgia.

Miltogramma argentifrons Townsend, Trans. Amer. Ent. Soc., vol. 18, p. 357, 1891.

Miltogramma cinerascens Townsend, Trans. Amer. Ent. Soc., vol. 18, p. 358, 1891.

Senotainia trilineata Coquillett, U. S. Bur. Ent., Tech. Ser., No. 7, p. 81, 1897.-Smith, Ins. of New Jersey, p. 778, 1909.-Johnson, Bull. Amer. Mus. Nat. Hist., vol. 32, p. 72, 1913.-Walton, Proc. U. S. Nat. Mus., vol. 48, p. 182, 1914.-Alddrich, An. Ent. Soc. of Amer., vol. 8, p. 82, 1915.-Gibson, Ent. Soc. Ont. Rept. 1919, p. 127.-Reinhard, Ent. News, vol. 30, p. 284, 1919.-Cole and Lovetw, Proc. Cal. Acad. Sci., vol. 11, p. 301, 1921.-Brimley, Ent. News, vol. 33, p. 25, 1922.-Curran, Can. Ent., vol. 55, p. 174, 1923.

Euselenomyia peruviensis Townsend, Proc. U. S. Nat. Mus., vol. 43, p. 364, 1912. Type from Peru.

Male.-Front at narrowest 0.24 of the head width (measurements of five as follows: $0.23,0.24,0.24,0.24,0.25)$; frontal vitta largely gray to golden pollinose; frontal rows not closely bordering the vitta, separated at their middle by distance greater than width of either parafrontal; small, black, bristly hairs on parafrontals below orbitals, 
which extend in an irregular row on parafacials almost to bucca; antennae black, excepting apex of second joint, which is red; in profile, buccal width exceeds that of paraíacial and equals one-fourth eye height; head length at vibrissae equals that at base of antennae; palpi yellow, usually with black tips. Thorax with three distinct postsutural dorsocentrals and two sternopleural bristles. Abdomen densely gray pollinose over black, without red spots on the sides, the narrow margins of the segments yellowish brown; with three more or less vague black spots on each of the last three segments; the second segment bears a strong median marginal pair of bristles, the third and fourth each with marginal rows. Genital segments and forceps subshining black; inner forceps (pl. 2, fig. 7) scarcely twice as long as broad, tapering uniformly to sharp, stout points curved sharply forward at tips, broadly divergent when viewed from behind; outer foreeps shorter than inner pair, curved inward to rounded spoon-like tips. Wings without costal spine; with one to two small bristles at base of third vein.

Female.-Width of front at narrowest 0.24 of head width (measurements of five as follows: $0.23,0.24,0.24,0.24,0.26)$; vertex, front and face more deeply golden pollinose than in the male; in profile, buccal width equals one-fifth eye height. Thorax and abdomen golden pollinose. Otherwise like the male excepting the usual differences in genitalia and size of pulvilli.

Length 3.0 to $7.0 \mathrm{~mm}$.

This species is one of the most common Muscoid flies of North America. Redescribed from a long series of both sexes from all parts of the United States, one male from San Carlos, Costa Rica (Schild and Burgdorf), and one female from Chinandega, Nicaragua (Baker). Townsend's eight specimens from Peru (Euselenomyia peruviensis), which are before me, differ slightly from the typical North American specimens in having the parafacials more bristly, and the first abdominal segment of the males and some of the females with a pair of distinct median marginal bristles. In much of the western material examined, which includes specimens from Colorado, Idaho, Nevada, New Mexico, Washington, and California, the three black spots on the intermediate segments of the abdomen are sharply defined from the surrounding white pollen, and the frontal bristles are noticeably weaker than in typical eastern specimens. The male genitalia of these Peruvian and western forms are apparently identical with that of the form from the eastern United States. After a careful study of available material I am inclined to retain all under tritineata.

Of four specimens of trilineata determined by me and forwarded to Major Austen, he finds that one is trilineata by comparison with the type. The others, however, appear to him to represent a different species, with which opinion I can not concur. The type of $54292-26 \hat{\dagger}-3$ 
Arrenopus americanus was loaned from the Vienna Museum for examination and the synonymy of Coquillett verified. Townsend's types for argentifrons and cineracens have been loaned by the University of Kansas Museum, and the synonymy of Coquillett and of Aldrich verified.

In the four specimens in which the female reproductive organs were dissected there was agreement in the following characters (pl.4, fig. 20): Spermatheca, three, their ducts elongate, without inflations, two of the ducts united on the distal half; accessory glands of equal size, somewhat less than ten times as long as their ducts; uterine pouch distinctly chordate; ovaries emptied, even before maggots in uterus had reached their full development.

The only difference in the morphology of the uterine maggot noted between this species and others of the genus studied, is found in the buccopharyngeal apparatus (pl. 5, fig. 31). In this, the median hook is suddenly constricted just beyond the base, expanding again near the tip, thence tapering to a stout point, the axis of which is almost perpendicular to the axis of the buccopharyngeal apparatus; lateral hooks with broad, nearly parallel sides to near tips, thence tapering abruptly to minute recurved points having a deep U-shaped invagination on ventral margin.

The puparium very closely resembles that of vigilans and rubriventris, from which, however, it differs in minor characters. It is chestnut brown in color, with minute spines encircling the anterior part of the thoracic segments; each segment with fine lateral striations, the anal segment without well defined spines above the depression. In lateral view, it is deepest at the middle, tapering slightly in both directions; the dorsal margin is straight; the ventral margin broadly convex. Anterior spiracle with six to seven papillae; posterior spiracles separated by a distance slightly greater than their width, and located slightly above the horizontal bisecting plane. Anal depression shallow.

The known range of trilineata is greater than that of any other species of the genus. Northward it has been recorded as far as New Hampshire, Ontario, Illinois, Minnesota, Canadian Northwest Territory, and British Columbia. Curran reports it from Fort Simpson, near $62^{\circ}$ latitude, far north of the known distribution of any other species of this group, and not far from the Arctic Circle. Southward from this limit it has been reported from numerous localities representing nearly every state of the United States, and from Mexico, Nicaragua, and Costa Rica. Townsend has recovered what is in all probability the same species from Peru. It is not known outside of the American continents.

Notwithstanding its abundance and wide distribution, but very little has been published on the biology of this species. The writer 
has had this form under observation at frequent intervals during the past three seasons, and has been able to gather some information on its life cycle and ecology.

Adults are generally present throughout the warmer months. In Ohio, Mississippi, and the District of Columbia, where this species has been under observation, it was found to be more widely distributed over the terrain than any other species of Senotainia. It occurs, however, most commonly over barren sandy soil such as is found along river banks, and on denuded ground, such places being sought out also by the fossorial Hymenoptera with which it is associated. The adults are not often found on rank vegetation except when attracted by the blossoms of certain plants, but they visit in conspicuous numbers, a considerable number of flowers including Erigeron, Anthemis cotula, and Euphorbia corollata. In the southern states, in early fall, they are attracted in large numbers to cowpeas, where they secure some food substance at the tip of the pod-bearing stalks. They frequently appear on Erigeron and cowpeas, even when these occur in dense stands on low rich ground at considerable distances from barren soil.

Few published records can be found concerning the host relationships of this species. There is one record of its issuance from a nest of Sphecius speciosus. ${ }^{19}$ It is also reported as having been reared from the common army worm, ${ }^{20}$ but this is so definitely at variance with the usual activity of this species and its allies as to be decidedly questionable. In a recent interesting article on the "ovipositional" habit of trilineata, ${ }^{21}$ Curran mentions other species of fossorial $\mathrm{Hy}$ menoptera, none of which were linked with this species in a wholly convincing manner. The writer has reared several specimens from the nests of Bicyrtes quadrifasciata. Prof. J. B. Parker secured several specimens from a nest of Bicyrtes ventralis. The three wasps from which it has been reared are Bembicidae which burrow in the sand. One stocks its nest with flies, largely Muscoidea, the other two with Hemipterous nymphs. Bembicid wasps, according to the writer's observations, are never as abundant as trilineata adults; therefore it seems probable that the latter will be found by further observation to issue from the nests of several other common species of Hymenoptera.

Professor Parker has submitted the following information regarding the rearing of trilineata from Bicyrtes ventralis at Washington, D. C. On June 13, 1914, the wasp "was discovered storing a nest with nymphs of a Hemipterous insect. It was marked and was opened on June 20, 1914. It contained the remains of seven bugs and ten fly puparia. No trace of the larval wasp was found. The

\footnotetext{
10 Coquillett, U. S. Bur. Ent, Tech. Ser., No. 7, p. 20, 1897.

20 Forbes, Psyche, vol. 6, p. 467, 1893.

${ }_{21}$ Can. Ent., vol. 55, p. 174, 1923.
} 
puparia were four inches below the surface of the ground. The soil was a sandy loam. The puparia were put in a breeding cell. On July 4, 1914, all flies had emerged."

The writer secured the following information in rearing from Bicyrtes quadrifasciata. A female was noted intently watching the wasp building its burrow and was captured and identified. A single nest from a lot of several collected in this colony was found to be infested with six maggots, all of which proved to be trilineata. The development of the maggots in this nest proved to be almost identical with that of the larvae of S. vigilans, previously discussed. The maggots remained undiscovered until after the wasp egg had hatched, but the grub of the wasp failed to develop since it was soon overwhelmed by the rapidly growing Dipterous larvae. In this case, all the stores of the wasp were consumed, the maggots spending the greater part of their developmental period as Sarcophagidlike scavengers in the midst of the decomposing bodies of the bug nymphs. The larval period from the time the nest was collected to the formation of the puparium was four to five days. Since the nest was not collected at actual larviposition time, the total larval period may have been a day or two longer. Puparia were formed in damp sand beneath the débris of the nest. The pupal period ranged from eight to eleven days, four of the six that were reared emerging on the ninth day.

Regarding the establishment of parasite on host, the writer has made no direct observations. Curran states that $S$. tritineata females poise over the entrance of the burrow and drop eggs directly into it as the wasp drags her prey down into it. The white objects seem dropping into the burrow, which he plainly states were not recovered for closer examination, were in all probability active, naked larvae, such as are readily demonstrated in the uterus of this and all nearly related species. The writer has dissected several gravid females of $S$. tritineata, in all of which the uterus was filled with large white maggots not exceeding 75 in number.

Several workers have noted the presence of annoying and persistent Dipterous parasites in connection with their studies of the bionomics of various fossorial Hymenoptera. Most of them have reared these parasites in sufficient numbers to be impressed with the idea that they constitute a heavy drain on the economy of the wasps. Several have noted that the wasps frequently turn on their wary pursuers, and attempt to drive them away. None, however, seem ever to have observed the wasps catching these elusive little flies. But observations made by the writer indicate that one species of wasp not only catches these flies but uses them to provision its nest. Several nests of Bembix spinolae were dug out at Columbus, Ohio, in the summer of 1921, which were found to contain the dismembered chitin- 
ous remains of many flies, as they had been left by the feeding stages. These were taken to the laboratory and carefully examined, and found to contain, among others, the dismembered parts of what was unquestionably S. tritineata. Heads and male genitalia, both of which are sufficient for diagnostic purposes, were isolated from the general débris. This observation indicates a unique relationship between these two species. The wasp, which provides its nest with flies of several species, apparently does not hesitate to use the bodies of its Senotainia parasites when they can be captured, while the fly lurks about its enemy and host, infesting its nest with maggots, whenever opportunity offers. We have here then, an interesting case of wasp predaceous on $\mathrm{fly}$, and fly in turn parasitic on wasp. But stranger still, Senotainia maggots in the nests of this wasp must be accustomed to subsisting in part on the bodies of the adults of their own species, when such are provided by the host. In fact, it is not improbable, as our discussion at another place of experiments performed with this species will show, for this wasp by capturing and carrying into its nest the body of a mature female Senotainia, to unwittingly infest its nest with the parasite.

In connection with the work on S. trilineata, it was discovered that larvae carefully pressed from the body of gravid females were capable of readily establishing themselves under artificial conditions. It appears worth while to dwell briefly on the information secured through them, first because our knowledge of the habits of the immature stages of this group have not been thoroughly worked out and secondly because it serves to further establish the Sarcophagid affinities of the group.

In one experiment, several active maggots squeezed from a gravid female were placed on nymphs of Leptoglossus, artificially paralyzed by crushing the head, to simulate the condition of the normal food. The maggots started to feed at once, through holes torn in the exoskeleton, at joints not heavily reinforced, such as the leg sockets. They frequently buried their body up to the anal plate in the feeding punctures. The maggots developed normally, so far as could be discovered, becoming in their later instars scavengers on the decaying bodies of the bugs. Two of the lot formed puparia, which, however, failed to emerge.

In another instance, the body of a female which had been allowed to lie in the cage for a day following death, was found to contain several healthy maggots which had consumed the softer tissues within the body of their mother. These were placed on the body of a freshly killed adult Leptoglossus and started immediately to wander over the body in search of food, seeking the softer places in the integument where they proceeded to make punctures by raking backward and forward with the mouthhooks. The morning after placing on pre- 
pared food, the lot was examined. Four were found with the anterior end inside the body of the bug, entrance having been secured through rents torn between the sclerites, the posterior third of the maggots were exposed.

In another experiment, maggots squeezed from the female were placed on Leptoglossus nymphs artificially paralyzed, two maggots to each of five nymphs. All of the maggots established themselves but one. The nymphs were carefully examined the following day, and showed no external evidence of the parasites, in this respect differing from the two previous experiments. One was dissected and both maggots, early in the second instar, were found wholly within the body of the host, which was dead, but whose tissues had as yet shown no signs of decay. On the following day, or when the maggots were two days old, another nymph was dissected, and found to contain both maggots, in the second instar, wholly concealed within the body, apparently in excellent condition and feeding on the body contents, now brown, semifluid, and in a moderately advanced state of decay. On the following day, all the remaining nymphs were dissected and the maggots were found to be dead, quite likely because of the extensive desiccation of the food material.

These experiments with the maggots of S. trilineata are too limited to serve as a satisfactory basis for generalization, but certain points are indicated which it māy be allowable to express. First, it is evident that this species is not a primary parasite of the wasps with which it associates, nor yet is it a commensal in the ordinarily accepted sense of that term. No term seems to exactly describe the relations of these two forms. The maggot is at first a true parasite on the living insects captured by the wasp, in the later stages becoming a scavenger on their putrifying bodies, and incidentally it may assume the rôle of predator on the young of the wasp for which the paralyzed insects have been provided.

\section{SENOTAINIA RUFIVENTRIS (Coquillett)}

Hilarella rufiventris Coquillett, U. S. Bur. Ent., Tech. Ser., No. 7, p. 129 1897. Type from Holly Springs, Mississippi, located in National Museum. Eusenotainia rufiventris Townsend, Proc. Biol. Soc. Wash., vol. 26, p. 22, 1915.

This species was without question incorrectly placed by Coquillett in the genus Hilarella. Townsend recognized this and proposed a new genus without describing it. The species possesses all the typical characters of the rubriventris series of Senotainia from which it differs slightly in possessing somewhat longer face and antennae. In the writer's opinion these are not variations of generic significance, and the close relationship with the rubriventris series can best be recognized by retaining it in the same genus. 
Male.-Front at narrowest 0.37 of the head width (measurements of three $0.36,0.36,0.38$ ) ; orbits most nearly approximated at base of antennae, diverging slightly above, widely below, with a slight emargination at the level of vibrissae; front and face silvery pollinose, frequently grayish or golden pollinose at the vertex; frontal vitta triangular, yellowish, submerged posteriorly beneath dense pollen; frontal rows with about nine bristles, separated at middle by distance almost equal width of parafrontal; one reclinate and two proclinate orbital bristles; parafrontals destitute of bristly hairs; vibrissae strongly approximated, nearly the length of second antennal joint above the front edge of oral margin; facial ridges with two or three bristly hairs on their lowest fourth; antennae red, extending seveneighths distance to vibrissae, third joint five times as long as the second; arista thickened nearly to tip, penultimate joint slightly longer than broad; parafacials bare; in profile, width of bucca equals parafacials and is one-tenth eye height, head length at vibrissae is distinctly less than at base of antennae, front projects more than one-third eye width; palpi yellow. Thorax gray pollinose over black, without distinct vittae; two postsutural dorsocentral bristles are distinguishable; two sternopleurals present; the scutellum bears three marginal pairs of which the apicals are the strongest; weak preapicals present. Abdomen largely red, fourth segment black, the third partly so; last three segments with thinly pollinose bands on their basal half; first two segments without bristles, third and fourth with marginal rows of about ten weak ones. Genitalia black, in repose, protruding from abdomen for distance equal to one-half the length of fourth abdominal segment. Wings without costal spine; third vein with a single small bristle at its base. Legs black; middle tibia with a single bristle on outer front side near middle; hind tibia on outer surface with several weak bristles on proximal three-fifths.

Female.-Front at narrowest 0.29 of the head width (measurements of three $0.28,0.29,0.30)$; frontal vitta narrower than in the male; frontal rows at their middle separated by a distance equal to twothirds width of parafrontal; distance of vibrissae above the oral margin fully equals the second antennal joint; vibrissae more strongly approximated than in male; third antennal joint two and one-half to three times the second. Otherwise, except for the usual sexual differences of the pulvilli and genitalia, like the male.

Length 3.0 to $6.0 \mathrm{~mm}$.

Type--Male, Cat. No. 3755, U.S.N.M.

Host relationships.-Unknown.

Redescribed from the type, and two males and one female of the type series from Holly Springs, Mississippi (F. W. Mally); one male, Lafayette, Indiana (J. M. Aldrich); one female, Owen's Lake, California (J. M. Aldrich); all in the collection of the National 
Museum: one female, Phoenix, Arizona (A. K. Fisher), in the collection of J. R. Malloch: and one female, Holly Springs, Mississippi (H. W. A.), in my collection. The specimen from Owen's Lake has an arista with a rather long penultimate joint but agrees in other respects with the typical, and is probably the same species.

\section{Genus OESTROHILARELLA Townsend}

Oestrohilarella Townsend, Insecut. Insc. Menst., vol. 6, p. 162, 1918. Genotype, Hilarella aristalis Coquillett from southern Illinois.

Readily distinguishable from Hilarella, Phrosinella, and Eumacronychia by the absence of any definite angle between the facial and buccal margin, when viewed from the side, and the presence of a globose or subglobose abdomen upon which the macrochaetae are scarcely differentiated. The genus also differs from Hilarella in having the last section of the fifth vein much less than half as long as the preceding section, and in the absence of a costal spine; from Phrosinella in having the lunule minute and largely concealed, the frontal rows not extending beyond the base of the antennae and not suddenly divergent below, the parafacials not suddenly constricted near the lower inner corner of the eye; from Eumacronychia in not having the pollen of the abdominal segments limited to dense, even, basal bands. Other distinguishing characters are as follows; a single frontal row on either side of the vitta; orbital bristles present in both sexes; antennae extending much more than half the distance to the vibrissae, which are inserted just above the oral margin; proboscis much shorter than head height; small bristly hairs on less than the lowest half of the facial ridges; in profile, head length at vibrissae much less than at base of antennae; no pale hairs on bucca or back of head about the oral cavity; two sternopleural bristles present; wings with but a few bristles at base of third vein.

A single North American species is referable to this genus.

\section{OESTROHILARELLA ARISTALIS (Coquillett)}

Hilarella aristalis Coquilletr, U. S. Bur. Ent., Tech. Ser., no. 7, p. 129, 1897.

The front of the male is disticntly wider than that of the female (measurements of the ratio of the front at narrowest to head width, for males an average of 0.365 for two measuring 0.36 and 0.37 , respectively; for females an average of 0.308 for six measuring $0.29,0.29,0.30,0.31,0.33$, and 0.33 , respectively); one reclinate and two proclinate orbital bristles; frontal vitta black and at level of lowest orbital slightly wider than either parafrontal; third antennal joint black, three times as long as the second; arista thickened on basal three-fourths; parafacials bare on lower half. Thorax gray pollinose with four distinct black vittae; three postsutural dorsocen- 
tral bristles present; scutellum with three nearly equal pairs of marginals. Abdomen densely gray pollinose, the intermediate segments when viewed from the rear each with three large, vaguely defined, triangular black spots. In the female, sclerites which appear to be the fourth, fifth, and sixth sternites but which are very likely part of the genitalia, together with the lower valve of the genitalia, cause a conspicuous bulge in the lower, posterior part of the abdomen. Wings hyaline; apical cell closed or narrowly open at margin of wing; hind cross-vein not parallel to section of fourth vein beyond the bend. Legs black, rather short and stout; middle tibia with one bristle on outer front side near middle.

Length 4.0 to $5.0 \mathrm{~mm}$.

Type--Male, Cat. No. 3634, U.S.N.M.

Host relationship. Unknown.

Range.-New York, Virginia, Indiana, Illinois, Colorado, Arizona, California, British Columbia.

The following material has been examined: The type, which is a male from southern Illinois (Robertson), and a female from Santa Clara county, California (Baker), of the type series; two from Colorado (Coquillett), two from Lafayette, Ind. (J. M. Aldrich); and other specimens from Kaslo, British Columbia (R. P. Currie); Oswego, New York; Tuscon, Arizona (J. M. Aldrich); all in the collection of the National Museum. Two females from Falls Church, Virginia in the collection of Mr. Nathan Banks.

\section{Genus OPSIDIA Coquillett}

Opsidia Coquillett, Journ. New York Ent. Soc., vol. 3, p. 102, 1895; Proc. U. S. Nat. Mus., vol. 37, p. 580, 1910. Genotype, O. gonioides Coquillett, Atlantic City, N. J.-Adams, in Williston's North American Diptera, p. 376, fig. 151, No. 90, 1908.-Townsend, Smithsonian Misc. Colls., vol. 41, p. 64, 1908.

In Coquillett's description of the genus, only a single male was available, and some of the characters given can scarcely be considered more than specific. The outstanding characters of the genus based on the genotype, and a new species, O. metopioides, are as follows:

Front with a single frontal row of bristles on either side of the vitta, which extend downward to slightly below base of antennae; proclinate ocellars present; orbital bristles in both sexes. The facial depression deep and narrow with parallel sides, is the most distinctive character of the genus. Facial ridges with bristly hairs not extending above the lowest fourth; vibrissae differentiated, and inserted far above front edge of oral margin; antennae extending nearly to vibrissae; arista with penultimate joint less than twice as long as wide; in profile, head length at vibrissae much less than at base of antennae; bucca and back of head black setulose, without pale hairs about the oral cavity; proboscis slender, at most slightly 
shorter than head height; palpi well developed. Thorax with two sternopleural bristles. Genitalia of male (pl. 1, fig. 5), small, and in repose, scarcely protruding from tip of abdomen; of female, retracted and non-piercing. Wings with apical cell open; last section of fifth vein distinctly less than half as long as preceding section; costal spine wanting; middle tibia with one macrochaeta on outer front side near the middle; hind tibia on outside with row of uneven bristles extending from base to apex.

KEY TO NORTH AMERICAN SPECIES OF OPSIDIA

1. Front, at base of antennae, twice as wide as either eye; arista thickened

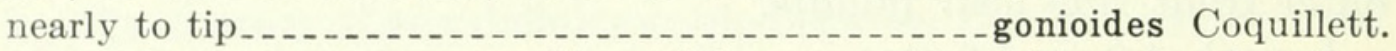

Front, at base of antennae, as wide as either eye; arista thickened on less than the basal half

OPSIDIA GONIOIDES Coquillett

Opsidia gonioides Coquillett, Journ. New York Ent. Soc., vol. 3, p. 102' 1895; U. S. Bur. Ent., Tech. Ser., no. 7, p. 128, 1897.- -ммгтн, Ins. of New Jersey, p. 782, 1909.

The distinctive characters of this species are as follows: Female closely resembles the male. Inner orbits parallel from vertex to bucca; front approximately twice the width of either eye and of equal width in both sexes; ratio of front to head width in males averages 0.496 (in five measuring $0.49,0.49,0.50,0.50,0.50$ ), in females a verages 0.493 (in tour measuring $0.48,0.48,0.50$ and 0.51 ); the frontal vitta is red, densely overlaid with golden pollen; much narrower at base of antennae, expanding abruptly at middle to width greater than either parafrontal; ocellar bristles directed laterally; one reclinate and two proclinate orbital bristles present, parafrontals densely black setulose, the bristly hairs continuous downward over the parafacials, to tip of antennae; vibrissae inserted more than length of second antennal joint above front edge of oral margin, but a collapsible membranous area at this point makes this character widely variable; second joint of antennae red; third joint black; arista thickened on basal four-fifths; parafacials with a row of small macrochaetae bordering facial ridges; palpi yellow; in profile, buccal width is subequal to that of parafacials and equal to one-fifth eye height, front projects a distance nearly equal to horizontal eye diameter. Thorax densely pollinose, with two somewhat obscure, divergent median vittae, and a pair of lateral convergent vittae most clearly defined caudad of transverse suture; three postsutural dorsocentral macrochaetae, of which the first is scarcely differentiated from the surrounding bristly hairs; scutellum with three pairs of strong, nearly equal macrochaetae. Abdomen densely gray pollinose, with dark reflections, but without definite spots or polished apical bands; second segment, and usually the first, with a median marginal pair 
of bristles; third and fourth segments with marginal rows; macrochaetae on first three segments short, on anal segment slightly larger. Wings hyaline; third vein with four or five bristles extending less than half way from base to small cross-vein. Legs black; the basitarsus of front leg in male slightly longer than last tour joints, in female distinctly shorter; pulvilli much shorter than last tarsal joint and of equal size in both sexes.

Range.-Massachusetts, New Jersey, Maryland, Mississippi, Ohio, Indiana, Wisconsin, Iowa, Nebraska, New Mexico.

Host relationships.-Unknown.

The following material has been examined. The type, a male from Atlantic City, New Jersey, in the collection of Dr. C. W. Johnson; males and females from the following localities: two, Horseneck Beach, Massachusetts, (Coquillett); Iowa; Chesapeake Beach, Maryland (R. C. Shannon); Las Cruces, New Mexico, (C. H. T. Townsend); Lincoln, Nebraska, (O. C. Bradbury); twenty-nine, Lafayette, Ind. including two labeled "from Asclepias incarnata" and one, "flowers of Solidago" (J. M. Aldrich); two, Crawfordsville, Indiana; all in the collection of the U. S. National Museum, including the Aldrich collection. Six specimens from Sandusky, Ohio, Cedar Point, in the collection of Prof. J. S. Hine. Specimens from Milwaukee, Wisconsin. (S. Graenicher); Chesapeake Beach, Maryland; Massachusetts; Lafayette, Indiana; in the collection of the Museum of Comparative Zoology at Cambridge, Massachusetts, and in that of Nathan Banks. Two from Tupelo, Miss. (H. W. Allen); two, West Springfield, Massachusetts, (H. E. Smith); in the collection of the writer.

Very little is known of the biology of this species. Dr. J. M. Aldrich's observations indicate that the adults are attracted to flowers. The reproductive organs of two dried specimens have been studied. One was found to contain 61 and the other 79 eggs, which is a rather large number for Miltogramminine flies. The eggs (pl. 4, fig. 26) were elongate, all at nearly the same stage of development, and in one of the specimens contained partly developed maggots in which the buccopharyngeal apparatus was faintly visible, the thin, delicately reticulated chorion was persistent over the anterior end of the maggot, but was rolled away from the posterior end of the body. Owing to the condition of the specimens dissected, it was impossible to determine the nature of the internal reproductive organs, but from the presence of partially developed maggots already partly freed from the chorion, it is probable that the species deposits active maggots. 
Front at narrowest point, in single specimen measured, 0.35 of head width; inner orbits most nearly approximated at base of antennae, diverging moderately and equally to vertex and bucca; frontal vitta black, narrowest at base of antennae, sides diverging to vertex, vitta at level of lowest ocellus, slightly wider than either parafrontal; parafrontals gray pollinose; about thirteen bristles in the single frontal row, which extends downward as far as base of second antennal joint; one reclinate and two proclinate orbital bristles, which are much stronger than bristles in frontal rows; sparse bristly hairs on front outside of macrochaetae; vibrissae inserted one and one-half times length of second antennal joint above front edge of oral margin; facial ridges nearly parallel; bearing two bristly hairs just above the vibrissae; antennae extend five-sixths the distance to vibrissae; second joint red; third joint black, four times as long as second; arista thickened on basal two-fifths; in profile, width of bucca equals that of parafacials, and is one-sixth eye height, front protrudes onethird the eye diameter; parafacials with sparse microscopic hairs. Bucca with very fine, black hairs; palpi yellow. Thorax golden pollinose over black, with three somewhat obscure black vittae, perceptible to scutellum; three postsutural dorsocentral bristles of which the first is scarcely larger than the surrounding bristly hairs; seutellum uniformly pollinose, with three pairs of marginal bristles; prescutellars scarcely differentiated. Abdomen black, the bases of the last three broadly, and the first segment entirely, pollinose; first and second segments each with a pair of median marginal bristles; third and fourth with median marginal rows of ten to fourteen bristles. Genitalia black. Wings hyaline; penultimate section of fourth vein equaling three-fifths the preceding section; hind crossvein nearly parallel to section of fourth vein beyond the bend; third vein with row of small bristles extending nearly to small cross-vein. Legs black; pulvilli half as long as last tarsal joint.

\section{Length, $7 \mathrm{~mm}$.}

Type.-Male, Cat. No. 28152, U.S.N.M.

Described from one male, Porto Bello, Panama, April 22, 1912. (A. Busck.)

\section{Genus OPSIDIOPSIS Townsend}

Opsidiopsis Townsend, Proc. U. S. Nat. Mus., vol. 56, p. 544, 1919 . Genotype, oblata Townsend, from Wild Horse Canyon, Animas Mountains, New Mexico.

This genus was erected by Townsend to receive a single species having the habitus of Opsidia from which it is readily distinguished by the row of bristly hairs on the first vein and the last section of the fifth vein being distinctly more than half as long as the preceding section. The presence of the bristly first vein is unique, serving to 
distinguish the genus from all other known North American Miltogramminae. Other outstanding characters are as follows; the presence of a single frontal row, the macrochaetae of which descend below the base of the antennae; vibrissae inserted near oral margin; antennae extending nearly to vibrissae; parafacials with a row of macrochaetae near the facial ridges which increase in size, downward. Thorax with two sternopleural bristles. Wings with first apical cell open and ending far before extreme wing tip; fourth vein with the usual strong fold at the bend. Middle tibia on outer front side near middle with a single macrochaeta.

\section{OPSIDIOPSIS OBLATA Townsend}

Opsidiopsis oblata Townsend, Proc. U. S. Nat. Mus., vol. 56, p. 544, 1919.

Chaetoplagia modesta Rernhard, Ann. Ent. Soc. Amer., vol. 14, p. 234, figs. 9, $10,1921$.

The synonomy given above was pointed out to me by Dr. J. M. Aldrich who had previously compared the types. In this species the third antennal joint and the palpi are black; the frontal vitta at its middle is fully three times as wide as either parafrontal; the thorax is marked with four black vittae; three postsutural dorsocentral bristles are present; the scutellum bears three pairs of long marginals; the last three abdominal segments are white pollinose on the broad bases, with polished black apices; the first abdominal segment is without median marginal bristles, the second and the third each bears a marginal pair, and the fourth a marginal row; the costal spine of the wing is minute.

Type--Female, Cat. No. 22090, U.S.N.M.

Host relationships.-Unknown.

Range.-Utah, New Mexico, Texas.

The following material has been examined. The type, a female from Wild Horse Canyon, Animas Mountains, New Mexico, 5,000 feet (C. H. T. Townsend), in the National Museum; one female from College Station, Texas, type for (Chactoplagia modesta Reinhard (H. J. Reinhard); and one other specimen from North Bear Run, Utah (A. Wetmore). Townsend reports collecting the adult on tender mesquite foliage.

\section{Genus METOPIA Meigen}

Metopia Meigen, Illig. Mag., vol. 2, p. 280, 1803. Genotype, Musca leucocephala Rossi from Europe.-Schiner, Fauna Austr., vol. 1, p. 488, 1862.Brauer and Bergenstamm, Zweifl. d. Kaiserl. Mus., vol. 56, p. 114, 1889; vol. 60, p. 168, 1893.-VAN Der Wulp, Biol. Cent.-Amer., Dipt., vol. 2, p. 114, 1890.-Coquillett, U. S. Bur. Ent., Tech., Ser., No. 7, p. 127, 1897; Proc. U. S. Nat. Mus., vol. 37, p. 569, 1910.-Adams, in Williston's Manual of N. A. Dipt., p. 376, fig. 151, no. 88, 1908.-Townsend, Smithson. Misc. Coll., vol. 51, p. 56, 1908; An. Ent. Soc. Amer., vol. 4, pp. 130, $140,1911$. 
Ophelia Robineau-Desvoidy, Myod., p. 120, 1830. Preoccupied 1817 in Vermes. The genotype according to Bezzi and Stein, Kat. Pal. Dipt., vol. 3, p. 510, equals campestris in Metopia.-Townsend, Ins. Ins. Menst., vol. 4, p. 8 gracilis Robineau-Desvoidy designated as type.

Araba Robineau-Desvoidy, Myod., p. 127, 1830; Dipt. des Environs de Paris, vol. 2, p. 88, 1863. This name modified by the author to Arabella, for sake of euphony. Genotype designated by Desvoidy in 1863, Tachnia argyrocephala Meigen, which equals leucocephala Rossi, the genotype of Metopia.

Anicia Robineau-Desvoidy, Dipt. Envr. Paris, vol. 2, p. 99, 1863. Genotype, sabulosa which according to Bezzi and Stein, Kat. Pal. Dipt., vol. 3, p. 510, belongs in the genus Metopia.

Arabella Robineau-Desvoidy, Dipt. Envr. Paris, vol. 2, p. 88, 1863. Genotype, Tachina argyrocephala Meigen considered by some European workers as synonymous with leucocephala and by others as a very nearly related species in the genus Metopia.

Argyrella Robineau-Desvoidy, Dipt. Envr. Paris, vol. 2, p. 87, 1863. Genotype, dissimilis which according to Bezzi and Stein, Kat. Pal. Dipt., vol. 3, p. 512, equals leucocephala in Metopia.

Argyria Robinenu-Desvoidy, Dipt. Envr. Paris, vol. 2, p. 82, 1863. Preoccuppied by Hubner in Lepidoptera, 1816. Genotype leucocephala of Rossi which, however, is type of Metopia.

Parametopia Townsend, Proc. U. S. Nat. Mus., vol. 49, p. 619, 1914. Genotype, morrisoni which equals lateralis Macquart and is congeneric with leucocephala. In this synonomy, I have followed Bezzi and Stein, adding to their list Townsend's Parametopia after comparison of genotypes.

The known North American species of the genus Metopia possess the following characters. Width of front is with some species greater in the male, in others in the female. There is a single frontal row on each side of the vitta, extending as far as, or slightly below, base of second antennal joint, suddenly divergent below; lunule conspicuous, nearly half as long as wide; small proclinate ocellar bristles present; orbital bristles in both sexes, four on each side, of which the lowest is proclinate, the uppermost reclinate, and the intermediate two decussate; facial ridges divergent, with small bristly hairs not extending above the lowest fourth; vibrissae nearly or quite level with oral margin; antennae extending nearly to vibrissae; penultimate joint of arista at most slightly longer than broad; parafacials with a row of strong macrochaetae bordering the facial ridges, becoming progressively larger as they approach the vibrissae; in profile, head length at vibrissae much less than at base of antennae, epistoma not visible, head with a pronounced conical contour; bucca and back of head with black bristly hairs, no pale hairs on the sides and back of oral cavity; facets of eye at extreme front but slightly larger than those at side of head; proboscis rarely one-half head height, very short and stout, with large fleshy labella; palpi moderate to very small in size or entirely lacking. Thorax with two sternopleural bristles and three strong postsutural dorsocentrals; scutellum with three pairs of strong marginal bristles. Pollen of abdomen usually interrupted by one to 
three irregular spots on each segment but never occurring in even, sharply defined basal bands; strong marginal abdominal bristles present, no discals. Genitalia of male (pl. 1, figs. 1, 2) small, in repose retracted within abdomen so as to be scarcely visible in profile view; females with the usual retracted larvipositors, without piercing parts. Wings with the apical cell open; fourth vein with a distinct fold at the bend; last section of fifth vein not more than half length of preceding section; costal spine wanting; only third vein bristly, and this with row of small bristles usually extending at least half way to small cross vein. Pulvilli of about equal size in both sexes and usually less than half as long as last tarsal joint; fore tarsus of male frequently ornamented with several long erect bristly hairs (pl. 3 , fig. 19); middle tibia with not more than one macrochaeta on outer front side near middle.

Townsend ${ }^{22}$ dissected one species of the genus and found that it possesses the typical double-pouched uterus of the Miltogramminae. Thompson ${ }^{23}$ who has studied the first instar maggots of leucocephala, lateralis, and campestris found that all possess a buccopharyngeal apparatus with a strong median stylet which articulates on the very slender dorsal accessory prece, two weak lateral hooks and the basal piece, the latter fused without articuiation to the intermediate piece. The cuticula of each segment is armed anteriorly by a band of minute, flattened, transparent scales, and posteriorly by a wider band of longitudinal corrugations.

The genus is represented in Europe, North and South America. In North America it does not have so extensive a range as Senotainia, not being known north of Grand Lake, Newfoundland, southern Quebec and Kaslo, British Columbia, or south of Cuba and Guerrero, Mexico.

The adults frequent denuded soil, low herbaceous vegetation, and in the case of some species, the foliage of shrubby plants in open forests. They are not known to be attracted to flowers but some species are drawn, in large numbers, to foliage smeared with the honeydew of Hemipterous insects. These flies are biologically superimposed upon fossorial Hymenoptera which nest in the ground, and have been reared from or found associated with species of several families including the Halictidae, Sphecidae, Bembicidae, and Cerceridae.

22 An. Ent. Soc. Amer., vol. 4, p. 130, 1911.

${ }^{23}$ Paris Edition du Bull. Biol. de la France et de la Belgique, Recherches sur les Diptères Parasites, pp. 110-114, 1921. 
KEY TO NORTH AMERICAN SPECIES OF METOPIA.

1. Frontal vitta at level of lowest orbitals, wider than either parafrontal _..._. 4 . Frontal vitta, at level of lowest orbitals, narrower than parafrontal _... _. 2 .

2. Anterior part of parafrontals conspicuously silvery; frontal vitta narrowed anteriorly to a line scarcely wider than lowest ocellus.

(male) leucocephala (Rossi).

Anterior part of parafrontals gray or leaden pollinose; anterior part of frontal

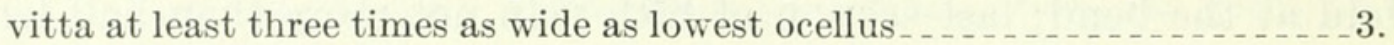

3. Pollinose area of parafrontals sharply limited posteriorly at level of lowest orbital bristles_.............................

Pollinose area of parafrontals not sharply limited posteriorly and continuous over vertex.............................. (female) leucocephala (Rossi).

4. Hind cross-vein strongly oblique to section of fourth vein before the bend; front, in profile, projects forward from the eye for a distance much less than horizontal diameter of eye _... 6 .

Hind cross vein nearly perpendicular to section of fourth vein before the bend _._.

5. Front, in profile, projects forward from the eye for distance greater than horizontal diameter of eye_............ perpendicularis Van der Wulp.

Front, in profile, projects forward from the eye for distance not more than one-third horizontal diameter of eye_._._....tessellata, new species.

6. Palpi, if present, smaller than thickened part of arista; middle tibia lacking bristle on outside below the middle _... _...

Palpi present and distinctly larger than thickened part of arista; middle tibia with a single bristle on outside below the middle; abdomen without yellow spots on its sides. 7 .

7. First abdominal segment with a pair of strong marginal macrochaetae; middle tibia below its middle with an encircling whorl of three bristles; male with several long wavy hairs on outside of fore tarsus

campestris (Fallén).

First abdominal segment without median marginal macrochaetae; middle tibia lacking whorl of three bristles near its middle; male without conspicuous long wavy hairs on outside of fore tarsus_._._._. inermis, new species.

8. With very small distinct palpi; males with long hairs or bristles arising from fore tarsus_._.

Without palpi, though sometimes with stubby rudiments; abdomen yellow on sides; males lacking long hairs or bristles on the fore tarsus

sinipalpis, new species.

9. Abdomen with pronounced yellowish spots on the sides; male with several long bristles on upper side of fore tarsus lateralis (Macquart). Abdomen usually wholly black; male with several long hairs on outside of

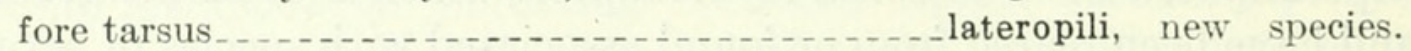

\section{METOPIA LEUCOCEPHALA (Rossi)}

Musca leucocephala Rossi, Fauna Etrusca, vol. 2, p. 306, No. 1504, 1790, Type from Europe.

Metopia leucocephala Meigen, Illig. Mag., vol. 2, p. 280, 1803.-Coquillett, U. S. Bur. Ent., Tech. Ser., No. 7, p. 127, 1897.-Bezzi and Stein, Kat. Pal. Dipt., vol. 3, p. 511-512, 1907, contains a full list of numerous references in European literature and 14 names of Robineau-Desvoidy assigned to synonymy.-Melander and Brues, Biol. Bull., No. 5, p. 20.-- Smith, Ins. of New Jersey, p. 782, 1909.-Thompson, Can. Ent., vol. 43, pp. 313-314, 1911.-Aldrich, An. Ent. Soc. Amer., vol. 8, p. 83, 1915.- 
Adams, Bull. Ill. Nat. Hist. Survey, vol. 11, p. 195, 1915.-Reinhard, Ent. News, vol. 30, p. 282, 1919.-Cole and Lovetr, Proc. Cal. Acad. Sci., vol. 11, p. 303, 1921.-Brimlex, Ent. News, vol. 33, p. 24, 1922.

Ophelia xychus WALKER, ? List 4, p. 70, 1849, after Aldrich.

Metopia roseri Rondani, Dipt. Ital. Prodr., vol. 3, p. 210, 1859, after Bezzi and Stein.

Metopia luggeri Townsend, Canad. Ent., vol. 24, p. 69, 1892.

Metopia meridiana Townsend, Proc. U.S. Nat. Mus., vol. 43, p. 361, 1912. After examination of type series at the National Museum.

There are only two North American species of the genus, so far discovered, leucocephala and opaca, in which the frontal vitta at the middle is distinctly narrower than either parafrontal. In the male of leucocephala the frontal vitta is obliterated anteriorly, while the front on either side is conspicuously silvery. In the female, the vitta is not constricted to a narrow line anteriorly, and the front is not conspicuously silvery. The palpi are black and distinctly larger than the thickened part of the arista. Thorax and abdomen are black, moderately pollinose and distinctly tinged with bronze. No yellow spots occur on the sides of the abdomen; the first two segments with a median marginal pair of bristles, the third with one or two laterals and a median marginal pair but never with an uninterrupted marginal row, the fourth with a marginal row of about eight. Wings hyaline; the hind cross vein nearly parallel to section of fourth vein beyond the bend. Legs black; front tarsuis of male without long erect bristly hairs, or abnormally reduced joints; middle tibia with one strong bristle on outer front side near the middle.

My notes on this species are based on the examination of several hundred specimens from all parts of the continental United States, southern Canada, Cuba, a few adults collected by Townsend in Peru and deposited in the United States National Museum ( $M$. meridiana) and several specimens from Europe including some determined by Professor Bezzi. Types of leucocephala, Q. xychus Walker and roseri Rondani as well as the numerous types of Robineau-Desvoidy which serve to swell the synonomy of this species, not seen, and their exact location not known to me.

Range.-Throughout continental United States; Newfoundland, southern Quebec and British Columbia, Canada; Peru; Europe.

The characteristics of the first instar maggots in the specimens studied by me agree in all but a few minor points with the descriptions and figures published by Thompson. ${ }^{24}$ I have examined several uterine maggots and find that the lateral hook does not have a blunt serrated tip as figured by Thompson but ends in a blunt point apposed to the tip of the median hook. The denticles, about mid-

${ }^{24}$ Paris Edition du Bull. Biol. de la France et de la Belgique, Recherches sur les Diptères Parasites, p. 111, fig. 105, 1921. 
way on the keel of the median stylet, so prominent in Thompson's figure, are lacking in my specimens. In the buccopharyngeal apparatus, the same parts occur, and in very nearly the same relative size and conformation as in the various species of Senotainia. The cuticula is found to possess, on every segment, an anterior band of flat, nearly transparent microscopic scales followed by a wider band of longitudinal corrugations, as in Senotainia. There are no heavily chitinized spines on the cuticula at any point. The uterine larvae are about $0.8 \mathrm{~mm}$. long and the buccopharyngeal apparatus is onefourth the length of the body. The other larval instars and the puparium of this species have not been studied.

The adults frequent sunlit, barren spots on low fertile soil surrounded by luxuriant herbaceous vegetation, such as denuded spots in a weedy field, or in such crops as rape and cowpeas. In such places the adults may be found in large numbers, darting about just above the surface of the soil, alighting now and then on the soil or on short dry sticks arising from the ground. They are not known to be attracted to flowers. On one occasion they were found in great abundance on rape, apparently attracted by a flow of honeydew from the heavy infestation of plant lice present.

$M$. leucocephala has been reported parasitic in the nests of the "sweat bees," on Halictus sexcinctus in Pomerania ${ }^{25}$ and on $H$. pruinosus in Massachusetts. ${ }^{26}$ The latter record is by Melander and Brues, who state that the adult fly chooses "the moment" when the incoming bee pauses at her threshold, quickly and quietly to oviposit on her pollen mass and thus infect her offspring." This species has also been observed hovering over the burrows of Chlorion atratum Lepeletier while the latter was digging in sand ${ }^{27}$ and Adams is credited with the observation that the larvae of Chlorion ichneumoneum are devoured by the Metopia maggots. ${ }^{28}$ Bezzi states that in Europe, M. leucocephala has been reared from Bembix, Halictus and Philanthus. ${ }^{29}$

METOPIA OPACA, new species

Male.-Front 0.39 of head width (measurements of five 0.37, 0.38, $0.40,0.40,0.40)$; vertex and upper part of parafrontals dull black, sharply defined from the dull leaden gray pollen of the anterior portion of parafrontals which is continuous down over face and bucca; frontal vitta black, not obliterated anteriorly, but narrowed to near base of antennae where it is nearly as wide as ocellar triangle, at level of lowest orbitals it is third width of parafrontal; about eleven bristles in frontal row which extends to below insertion of arista,

${ }^{25}$ Ridel, Allg. Zeitsch. f. Ent., vol. 6, p. 152.

${ }^{26}$ Biol. Bull., no 5, p. 20, 1903.

${ }_{27}$ Adams, Ill. Nat. Hist. Surv. Bull., no. 11, p. 195, 1915.

${ }^{28}$ Rau and Rau, Wasp Studies Afield, p. 197, 1918.

${ }^{20}$ Bezzi and Stein, Kat. Pal. Dipt., vol. 3, p. 511, 1907. 
widely divergent below, with an irregular group of several bristles within its angle of divergence, two bristles near middle of frontal row much larger than those on either side; one to three or more proclinate and about the same number of reclinate orbitals inserted irregularly on that part of parafrontal devoid of pollen; vertex and upper part of front thickly black setulose, pollinose part of front sparsely so; antennae black, third joint seven times length of second; arista thickened on basal two-fifths; parafacials densely black setulose on upper half, with usual row of stout bristles extending downward to level of uppermost bristle on facial ridge; in profile, buccal width much greater than that of parafacials at narrowest and equals onefourth eye height, front projects for distance nearly equal to horizontal eye diameter; palpi black, larger than the thickened part of arista. Thorax gray pollinose merging with bronze on mesonotum and scutellum, with four black vittae of about equal width, the inner pair divergent posteriorly and terminating at transverse suture. Abdomen densely gray pollinose, tinged with bronze on notum; pollen of first three segments interrupted by transverse rows of two to three large black spots, which on the intermediate segments coalesce in the form of a letter " $\mathrm{E}$," last segment polished black on apical third; first two segments with strong median marginal bristles, third with a strong median marginal pair and one or two pairs of strong laterals which fail to complete an uninterrupted marginal row, fourth with the usual marginal row. Wings subhyaline; hind cross-vein oblique to section of fourth vein before the bend, parallel to section beyond bend; third vein bristly more than half way to small cross-vein. Fore tarsus without conspicuous long bristly hairs on the side; middle tibia with one prominant bristle on outer front side beyond middle; hind tibia on outside with row of about twelve uneven bristles extending from base to apex.

Female.-Not known.

Length, 6.5 to $7.0 \mathrm{~mm}$.

Type.-Male. Cat. No. 28153, U.S.N.M.

Range.-Oregon, Montana, Ontario.

Host relationships.-Unknown.

Described from the following material: three, including the type, Marshfield, Oregon, VI-27 (J. M. Aldrich); one, Marshfield, Oregon, VI-28 (J. M. Aldrich); one, Summit Station, Montana, 5,200 feet, VII-25 (J. M. Aldrich); all in the National Museum: one, Ottawa, Ontario, 26-VII-1924 (C. H. Curran), in the Canadian National Collection.

The male closely resembles leucocephala in the rather striking, conical-shaped head. It may be readily separated, however, by its peculiar leaden pollinose front and the greater width of the frontal vitta anteriorly. It may be possible that females have been placed 
with leucocephala, since the only differences detected in those two species occurs in a region markedly different in the two sexes.

\section{METOPIA CAMPESTRIS (Fallén)}

Tachina campestris Fallén, Dipt. suec. Musc., col. 8, p. 12, 1820.-BezzI and Stein, Kat. Pal. Dipt., vol. 3, pp. 510-511, 1907. Contains many references in European literature for which there is not space in this paper.

Tachina amabilis Meigen, Syst. Beschr., vol. 4, pp. 374, 232, 1834.

Ophelia cinerea Robineau-Desvoidy, Myod., p. 121, 1830.

Ophelia gracilis Robineau-Desvoidy, Myod., p. 121, 1830.

Ophelia lutescens Robineau-Desvoidy, Myod., p. 121, 1830.

Metopia flavescens Macquart, Soc. Sci. Lille, 1833, p. 285, 1834.

Metopia crassicornis Perris, Soc. Linn. Lyon, 1852, p. 63.

Metopia staegeri Rondani, Dipt. Ital. Prodr., vol. 3, p. 210, 1859.

Ophelia caesia Robineau-Desvoidy, Dipt. Envr. Paris, vol. 2, p. 96, 1863.

Ophelia demissa Robineau-Desvoidy, Dipt. Envr. Paris, vol. 2, p. 98, 1863.

Male.-Front at narrowest 0.30 of head width (measurements of five $0.29,0.30,0.30,0.30,0.31$ ) ; front, face, and bucca gray pollinose with dark reflections when viewed from below; inner orbits strongly approximated at base of antennae, diverging widely towards vertex and bucca; frontal vitta black, diverging moderately toward the rear, about twice width of either parafrontal at level of lowest orbitals; about ten bristles in frontal row, which extends to middle of second antennal joint; parafrontals moderately pilose, with the black bristly hairs extending downward to insertion of arista; vibrissae level with front edge of oral margin; facial ridges with two or three bristles not extending above the lowest fourth; antennae black, extending to half the length of second antennal joint from vibrissae; third joint five to seven times as long as the second; arista thickened on basal two-fifths; in profile, bucca equals one-eighth eye height and is subequal to parafacials at narrowest point, front projects about one-third eye diameter; parafacials bare save for row of strong macrochaetae extending downwards to level of uppermost bristles on facial ridges; palpi black, much larger than thickened part of arista. Thorax thinly gray pollinose over black, with two narrow median and two broad lateral vittae before the transverse suture, and three broad vittae behind the suture which are obscurely continuous over the scutellum; the apical and lateral pairs of marginal scutellar bristles equal and both smaller than the intermediate marginal pair; small preapicals present. Abdomen shining black, with broad, reflecting, bronzetinged gray pollinose bands on basal two-thirds of the last three segments; intermediate segments with a median vitta and usually with large $\mathbf{V}$-shaped indentations in the pollinose bands on either side, when viewed from rear; first and second segments each with a strong median marginal pair of bristles; third and fourth each with uninterrupted marginal row of about ten bristles. Genitalia (pl. 1, fig. 2) black; in repose extruding but slightly from the fourth abdominal 
segment; first genital segment nearly bare save for subapical row of small bristly hairs; second genital segment and the base of inner forceps densely covered with fine bristly hairs; inner forceps in lateral view tapering somewhat abruptly to the middle and then more gradually to nearly straight, strong tips; from the rear the claws appear conical and are moderately divergent from near the base; outer forceps yellowish, shorter than the inner pair, with spoonshaped tips; fifth sternite enlarged and possessing a broad $U$-shaped cleft. Wings hyaline; fourth vein beyond the bend moderately arcuate, nearly parallel to hind cross-vein; last section of fifth vein distinctly less than half the preceding section; third vein bristly at least half way to the small cross-vein. Legs black; first four joints of front tarsus with several long slender erect hairs on outside (pl. 3, fig. 19); middle tibia near its middle with encircling ring of one weak and two strong macrochaetae; hind tibia on outside with a row of unequal bristles extending from base to apex.

Female.-Front at narrowest 0.36 of head width (measurements of five $0.35,0.35,0.36,0.37,0.39)$; inner orbits nearly straight and parallel, scarcely more nearly approximated at base of antennae than elsewhere; third joint of antennae five to six times length of second. Fore tarsus without long erect hairs on the outside. Otherwise, save for the usual differences of external genitalia, like the male.

Length, 5.0 to $6.5 \mathrm{~mm}$.

Range.-Maine, New Hampshire, Vermont, Massachusetts, Connecticut, New York, New Jersey, Maryland, District of Columbia, Virginia, Pennsylvania, Ohio, Michigan, Wisconsin, Colorado, Idaho, California, Europe.

Host relationships.-Unknown.

I have examined material from the following localities. Two specimens from Franconia, New Hampshire (C. H. T. Townsend); one, Lexington, Massachusetts; two, North Saugus, Massachusetts (D. C. Clemons) ; three, Waterbury, Connecticut (C. H. T.Townsend); a large series from Slaterville, Duck Lake, and McLean Bogs, New York (L. S. West); two, Plummer Island, Maryland (W. L. McAtee, H. L. Vierick); two, Rock Creek, District of Columbia (C. H. T. Townsend); one, Beltsville, Maryland (N. Banks); one, Great Falls, Virginia (H. W. Allen); one, Difficult Run, and one, Dead Run, Virginia (R. C. Shannon); one, Ravensworth, Virginia (C. H. T. Townsend); one, Battle Creek, Michigan (J. M. Aldrich); three, Polk County, Wisconsin (Baker); two, Peaceful Valley, Colorado (Cockerell); one, Tennessee Pass, Colorado, three, L. Metigoshe, Turtle Mountains, North Dakota, one, Moscow, Idaho, and one, Mount Lowe, California (J. M. Aldrich); one, Humboldt County, California (H. S. Barber); all in the collection of the National Museum. In the collection of the Boston Natural History Society, I have seen specimens from several 
places in Massachusetts; Mount Desert Island, Machias, Northeast Harbor, Maine; Manchester, Vermont: In Dr. C. W. Johnson's collection, specimens from Pennsylvania and New Jersey: In the collection at the Museum of Comparative Zoology at Cambridge, Massachusetts, a long series from Vermont, Massachusetts, New Jersey, and several localities in Virginia: In the collection of Prof. J. S. Hine, one specimen from Wauseon, and another from Johnson's Island, Ohio: In my collection, specimens from Lunenburg and Amherst, Massachusetts; Shenadoah River, Clarke County, and Great Falls, Virginia; and Columbus, Ohio.

European specimens determined by Professor Bezzi and deposited in the National Museum, I have examined and find to differ from the North American specimens only in possessing several rather weak marginal macrochaetae on the first and second abdominal segments lateral to the strong median marginal pairs. This in my opinion is not of sufficient significance to be considered a specific difference.

The identity of the American species with the European campestris was pointed out to me by Dr. J. M. Aldrich. In this country it has long been confused with leucocephala. Apparently Thompson had campestris in mind in his short paper on M. lateralis ${ }^{30}$ but a careful comparison with the description of Macquart indicates that the latter refers to another species. The synonomy submitted is after Bezzi and Stein; the types have not been examined by me.

\section{METOPIA INERMIS, new species}

Male.-Front in the single specimen measured 0.32 of head width; front, face and bucca gray pollinose; frontal vitta black, at lowest orbitals twice width of parafrontal; about ten bristles in frontal row which extends to middle of second antennal joint, with one or two bristles in the angle of divergence; parafrontals with sparse black bristly hairs to insertion of arista; facial ridges with two or three bristles not extending above the lowest fourth; antennae black, third joint three times length of second; arista thickened on basal third, penultimate joint slightly longer than broad; in profile, bucca wider than parafacials at narrowest and equal to one-sixth eye height, front projects forward from eye for distance greater than one-third horizontal eye diameter; palpi black, distinctly larger than thickened part of arista. Thorax gray pollinose, notum black, subshining, with four broad black vittae; scutellum with the intermediate marginal bristles larger than the equal apical and lateral pairs; small preapicals present. Abdomen black; last three segments with black polished apices and densely gray pollinose bases, the intermediate segments each marked with a series of three triangular spots coalesced at apex

${ }^{30}$ Canad. Ent., vol. 43, pp. 313-314, 1911. 
in form of a trident, pollen not tessellated or changing color when rotated in the light; first segment without apical marginals, second with a strong pair, third with an apical pair and several laterals, which are nearly as strong as the median marginals, not completing an uninterrupted marginal row. Genitalia, in repose, not extruding beyond tip of abdomen; both genital segments black. Wings hyaline; last section of hind cross vein sinuous and strongly oblique to section of fourth vein before the bend, parallel to section beyond the bend; third vein bristly more than half way to small cross vein. Legs black; fore tarsus without conspicuous long bristly hairs on outside; middle tibia with one rather weak bristle on outside beyond middle but lacking a whorl of three at this place; hind tibia on outside with row of about ten unequal bristles extending from base to apex.

Female.-Front in one specimen measured 0.34 of head width; frontal vitta at level of lowest orbitals one and one-half times width of parafrontal; third antennal joint four times length of second; buccal width one-ninth eye height. Last three abdominal segments with broadly polished apices, trident-shaped marks indistinct. Hind tibia on outside with seven bristles. Otherwise, except for usual differences of genitalia, like the male.

Length, 5.0 to $6.0 \mathrm{~mm}$.

Type and allotype.-Cat. No. 28154 U.S.N.M.

Range.-Utah, Maryland.

Host relationships.-Unknown.

Described from the two specimens - the male type from Soldier's Summit, Utah, 7,454 feet, July 6 (J. M. Aldrich) and female allotype from Chesapeake Beach, Maryland, August 19, 1919 (J. M. Aldrich). The female exhibits minor variations from the male, but possibly not more than might be explained by the wide difference in habitat. It is at least much more nearly related to the type of inermis than to any other North American species studied. From the closely related campestris, this species may be readily distinguished by the shorter third antennal joint, and by the lack of median marginal bristles on the first abdominal segment, the lack of an encircling whorl of three bristles on the middle tibia and the absence of conspicuous bristly hairs on the outside of the fore tarsus.

\section{METOPIA TESSELLATA, new species}

Male.-Front 0.34 of head width (measurements of three 0.33, $0.34,0.36)$; front and face gray pollinose with dark reflections; vitta black or brown, at level of lowest orbital bristles three to five times width of parafrontal; parafrontals sparsely black setulose to below uppermost macrochaetae of parafacial row; antennae black, third joint five to six times length of second; arista thickened on basal third; in profile, bucca wider than parafacials at narrowest, and 
equal to one-eighth eye height, front projects slightly more than onethird eye width; palpi black, of normal size. Thorax gray pollinose tinged with brown on notum, with four broad black vittae, the outside pair of which extend to scutellum, inner pair not extending beyond transverse suture. Abdomen black, somewhat flattened dorsovientrally; intermediate segments pollinose to apices, pollen strongly tessellated, changing abruptly from bronze to gray when rotated in the light, last segment pollinose on basal two-thirds; first segment without macrochaetae, second with a strong median marginal pair, third with a strong median marginal pair and several distinctly weaker ones on either side, in some specimens forming an uninterrupted marginal row, fourth with marginal row of bristles which increase gradually in size towards the median dorsal line. Wings subhyaline; hind cross vein straight and nearly perpendicular to fourth vein, which it joins almost halfway between its bend and the small cross vein; Third vein bristly nearly to small cross vein. Tarsus of fore leg slender, without conspicuous long bristly hairs on the outside; middle tibia with one small bristle on outer front side beyond middle but lacking an encircling whorl of three at this place; hind tibia on outside with a row of about nine unequal bristles extending from base to apex.

Female.-Front at narrowest 0.40 of head width (measurements of six $0.37,0.37,0.41,0.41,0.42,0.42)$. Otherwise, except for the usual differences in genitalia, like the male.

Length, 5.5 to $7.0 \mathrm{~mm}$.

Type.-Male, Hinckley, Ohio, VI-29-'01 (J. S. Hine) in the collection of Professor Hine.

Allotype.-Female, Hinckley, Medina County, Ohio, VI-29-'01 (J. S. Hine), also in the collection of Professor Hine.

Range.-Maine, Massachusetts, New York, Ohio, Maryland, Virginia.

Host relationships.-Unknown.

Described from the following material: in the collection of Professor Hine; one male and one female from Hinckley, Ohio: in the collection of Dr. C. W. Johnson; one male, Machias, Maine, VII-21 (C. W. Johnson); one female, New Bedford, Massachusetts; two females, Chester, Massachusetts, VII-25-'12 (C. W. Johnson); in the collection of J. R. Malloch, one male, Glen Echo, Maryland, Aug. 21, 1923 (J. R. Malloch) : in the collection of R. C. Shannon, one female, Renwick, Ithaca, New York, 19-VIII-'21 (L. S. West); in my collection, one female, Great Falls, Virginia, 15-VIII.

This species very closely resembles inermis from which it can be distinguished by the greater length of the third antennal joint, the wider frontal vitta, the distinctly tessellated and more extensively pollinose abdomen and the presence of a perpendicular hind cross 
vein. From campestris it may be readily distinguished by the absence of median marginal bristles on the first abdominal segment, the absence of a distinct whorl of three bristles on the middle tibia beyond the middle, in the comparatively weaker development of macrochaetae on the third abdominal segment laterad of the median marginal pair and in the presence of the perpendicular hind cross vein. Male differs further in having no conspicuous long bristly hairs on the side of the fore tarsus.

METOPIA LATEROPILI, new species

Male.-Front at narrowest 0.325 of the head width (measurements of two 0.31 and 0.34 , respectively); front and face silvery pollinose with dark reflections toward vertex; inner orbits most nearly approximated at base of antennae, diverging slightly toward vertex, widely towards bucca, with a concavity to accommodate the bulging parafacials; frontal vitta black, pollinose anteriorly, diverging slightly to middle, thence with parallel sides to vertex, width at lowest orbitals one and one-half to two times that of either parafrontal; about ten bristles in frontal row which closely borders the vitta, upper five or six bristles much the smallest; front with sparse black bristly hairs outside the frontal rows; vibrissae at level of front edge of oral margin; antennae black, extending to one-half length of its second joint from vibrissae, third joint four to five times as long as the second; arista thickened on basal two-fifths; parafacials bare save for row of strong bristles near facial ridges extending downward to level of uppermost bristles of the facial ridges; in profile, buccal width equals parafacials at narrowest, and is approximately one-tenth the eye height; front projects one-third the horizontal eye diameter; palpi yellow, filiform, and distinctly more slender than the thickened part of arista. Thorax thinly pollinose over shining black, notum bronzed and obscurely marked with three narrow median and two broad lateral vittae; scutellum uniformly bronze pollinose, with three pairs of nearly equal marginal bristles, no distinct preapicals. Abdomen black, without red or yellow spots on the sides, last three segments with gray pollinose bands on the basal two-thirds which are divided by an indistinct black vitta on the intermediate segments; second and third segments each with a median marginal pair of bristles, fourth segment with a marginal row of about eight. Genitalia small, black, in repose not extruding from the tip of the abdomen. Wings subhyaline; section of fourth vein beyond the bend slightly arcuate, oblique to hind cross vein; last section of fifth vein nearly half as long as preceding section; third vein bristly more than half way to small cross vein. Legs black; fore tarsus with several long slender erect hairs on the sides of the second, third, and fourth joints, fourth joint not conspicuously reduced; middle tibia lacking bristles on 
front side near middle; hind tibia on outside with row of about five uneven bristles extending from base to apex.

Female.-Front at narrowest 0.346 of head width (measurements of three $0.33,0.35$, and 0.36 ) ; fore tarsus lacking the long erect hairs on the outside. Otherwise, except for usual differences of genitalia, like the male.

Length, 4 to $5 \mathrm{~mm}$.

Type, Allotype, and Paratypes.-Cat. No. 28155, U.S.N.M.

Range.-Louisiana, Texas, New Mexico, Cuba.

Host relationships.-Unknown.

Described from two males (one type) and four females (one allotype) Havana, Cuba (Baker); one male, Shreveport, Louisiana, July 3, 1890 (F. W. Mally); one male, Kennedy, Texas, May 4, 1896 (Marlatt); and one male, Las Vegas, New Mexico, Aug. 17 (Barber and Schwarz); all in the National Museum.

The female of this species and of M. lateratis are sometimes difficult to separate since the presence of red or yellow on the sides of the abdomen and the color of the palpi seems to be a rather variable character. Males, however, are readily separated on the ornamentation of the fore tarsus.

\section{METOPIA LATERALIS (Macquart)}

Degeeria lateralis Macquart, Dipt. Exot. Suppl., vol. 3, p. 208, pl. 5, fig. 6, 1847. From North America.

Metopia lateralis Coquillett, U. S. Bur. Ent., Tech. Ser., No. 7, p. 127, 1897. As synonym of leucocephala.-Aldrich, Cat. N. A. Dipt., p. 476, 1905. Questions whether equals leucocephala.-Bezzi and Stern, Kat. Pal. Dipt., vol. 3, p. 512, 1907. Synonym of leucocephala.

Parametopia morrisoni Townsend, Proc. U. S. Nat. Mus., vol. 49, p. 619, 1914.

Male.-Front at narrowest 0.34 of head width (measurements of five $0.32,0.32,0.33,0.35,0.36)$; frontal vitta black, broadening slightly toward the rear, at middle more than twice as wide as either parafrontal; parafrontals gray to golden pollinose; frontal row with nine to eleven bristles extending to slightly below base of second antennal joint; numerous small black bristly hairs on front, more plentiful near base of antennae; vibrissae near oral margin; antennae black, extending to length of second antennal joint above front edge of oral margin; third joint four to five times as long as second; arista thickened on basal two-fifths, with short pubescence in middle; palpi smaller than thickened part of arista, filiform and usually black; in profile, front projects forward about one-fourth horizontal diameter of eye, bucca equals one-fifteenth of eye height; parafacials gray pollinose, bare save for the usual row of strong macrochaetae near the facial ridges which extend downward more than half way to vibrissae, but usually not reaching the level of the uppermost bristles of the 
facial ridges. Thorax gray pollinose, golden tinged, with three narrow, black median and two broad lateral vittae; scutellum with three pairs of marginal bristles of about equal size. Abdomen black, with a large yellowish spot extending over the sides of the first two and sometimes the third segments; basal two-thirds of last three segments gray pollinose when viewed from rear, the gray interrupted by black median dorsal $\mathrm{V}$-shaped emarginations; first segment usually lacking macrochaetae, second and third each with a median marginal pair, fourth with a marginal row of about eight. Genital segments black, subshining, sparsely covered with black bristly hairs; in repose, retracted within the last abdominal segment; inner forceps small, black, densely covered at base with fine black hair, claws tapering to slender curving points, divergent at tips, and when viewed from the rear display no angle on the outside near the base; outer forceps brown, shining, larger and stouter than the inner pair; anterior claspers unusually long, more slender than the largest of the abdominal bristles, curved forward and slightly enlarged at the extreme tip. Wings hyaline; fourth vein veyond the bend slightly arcuate and nearly parallel to hind cross-vein; third vein with a row of small bristles, extending in some specimens more than half way to small crossvein. Legs black, trochanters and frequently the upper part of femora yellow; second, third, and fourth joints of fore tarsus each with an erect bristly hair on the upper surface; fourth joint much reduced; middle tibia lacking macrochaetae on outer front side near the middle; hind tibia on outside with an uneven row of five to nine bristles extending from base to apex.

Female.-Front at narrowest 0.33 of head width (measurements of three $0.31,0.33,0.35$ respectively); frontal vitta pollinose, nearly concolorous with parafrontals. Genitalia nonpiercing, in repose inconspicuously telescoped within the fourth abdominal segment.

Length 3.5 to $6.0 \mathrm{~mm}$.

Specimens have been examined in the collections of the National Museum, Nathan Banks, and the writer, from the following localities: One female, White Mountains, New Hampshire (Morrison), type of Parametopia morrisoni Townsend; one male, Melrose Highlands, Massachusetts, July 31, and one female, West Springfield, Massachusetts, July 13, 1915 (H. E. Smith); two males and two females, Lafayette, Indiana; one male, Columbus, Ohio, Aug. 4, 1921 (H. W. A.); one male, New York, late July; one male, Linnieville, Maryland, July 4, 1913, and one female, Cabin John, Maryland (R. C. Shannon); one female, Rock Creek, District of Columbia (C. H. T. Townsend); three males, Chain Bridge, Virginia, August 12, 1923 (H. W. A.); eight females and two males, Fall Church, Virginia (N. Banks); one female, Lawrence, Kansas; one female, Birmingham, Alabama, June 4, 1917 (J. M. Aldrich); one male, Agricultural and Mechanical 
College, Mississippi, April 23, 1921, and two females, Meridian, Mississippi, Sept. 3, 1922 (H. W. Allen); one female, White Springs, Florida, Oct. 17 (C. H. T. Townsend); one female labeled "Parker Note no. 45," from Brookland, District of Columbia.

The type not seen and its present location not known to me. Marquart describes the species as having the sides of the abdomen rufous, and the palpi black, a combination of characters present in the above specimens but not found in any of the other North American species known to me. This common species has been long confused with leucocephala and campestris. In his Revision of the Tachinidae, Coquillett considers it synonymous with the former. ${ }^{31}$ Somewhat later, Thompson ${ }^{32}$ pointed out characters distinguishing it from leucocephala but failed to distinguish lateralis and campestris.

The known range of lateralis covers a large part of the eastern United States from New Hampshire, New York, Ohio, Indiana, and eastern Kansas to Mississippi and northern Florida. It has also been reported in Quebec. ${ }^{33}$ Adults of this species occur quite abundantly in sunlit spots, on the foliage of low shrubs and herbaceous plants, in open deciduous forest, or flying about just above the ground covering of dead leaves. It has also been taken, with other Miltogramminae, in sandy spots in open grassy pasture. Nathan Banks reports having collected it frequently feeding on honeydew on the dead leaves and low foliage under tulip tree, and the writer has taken it under the same conditions.

\section{METOPIA SINIPALPIS, new species}

Male.-Front at narrowest 0.33 of the head width (measurements of five $0.29,0.33,0.34,0.35,0.36)$; frontal vitta black, pollinose anteriorly, with sides parallel except near base of antennae, at lowest orbitals three to four times as wide as either parafrontal; parafrontals somewhat golden pollinose, with dark reflections when viewed from the front; nine to eleven bristles in the frontal row which extends to slightly below base of second antennal joint; a few black bristly hairs on parafrontals, more abundant at the extreme front, not extending below the upper half of the parafacials; vibrissae level with front edge of oral margin; facial ridges with three small bristles on the lowest fourth; antenna black, extending to less than length of its second joint above front edge of oral margin, third joint three or four times as long as the second; arista thickened on basal one-fourth; parafacials with a row of macrochaetae near the facial ridges, which extend from the base of the third antennal joint to level of the uppermost bristle of the facial ridge; in profile, bucca scarcely one-twelfth eye height; proboscis scarcely one-half head height; palpi lacking, 
or at most represented by rudimentary stubs. Thorax gray pollinose over black, the notum subshining, distinctly tinged with bronze, with three narrow median and two broad lateral vittae, the lateral one extending beyond the transverse suture; scutellum with three pairs of marginal bristles of about equal size. Abdomen black, broadly yellow on the sides of the first three segments, last three segments gray pollinose except for the narrow apices which are shining black, and a narrow dorsal vitta on the second and third segments; first segment without bristles, second and third segments each with a strong median marginal pair, third sometimes with a weak lateral bristle, fourth with a marginal row of six to eight bristles. Genitalia black; first genital segment slightly larger than the second; the subdiscal part of the first, the second and the base of the inner forceps clothed with black hairs somewhat finer than those of the abdomen; two small apical bristles on the first segment; inner forceps expanded laterally into a small but distinct angle near the base, plainly seen from the rear; anterior claspers extremely long, boomerang-shaped, not expanded at the tip, much stouter than the abdominal macrochaetae. Wings hyaline; section of fourth vein beyond bend moderately arcuate and nearly parallel with hind cross vein; last section of fifth vein less than half as long as preceding section; third vein bristly more than half way to small cross vein. Legs black, the trochanters, upper half of the femora and the front tibia usually yellow; front tarsus without conspicuous bristles or long hairs; middle tibia lacking bristles on outer front side near middle; hind tibia on outside with four or five bristles extending beyond the middle.

Female.-Front at narrowest 0.32 of head width (measurements of four $0.31,0.32,0.32,0.33$, respectively). Otherwise like the male except for the usual differences in external genitalia.

Length, 4.5 to $6.0 \mathrm{~mm}$.

Described from the following material. In the collection of the National Museum, one male, North Wilbraham, Massachusetts, Aug. 15, 1916 (D. A. Ricker); one male and four females from Lafayette, Indiana, one male, Chesapeake Beach, Maryland, June 21, 1923 (J. M. Aldrich); one female, Cupid's Bower Island, Maryland, July 8, 1915 (R. C. Shannon); one male, Chain Bridge, Virginia (H. W. A.); one male, Onaga, Kansas; one female, Opelousas, Louisiana, May, 1897. From Glen Echo, Maryland, one male, July 1, 1923, one male, August 10, 1923, one male, Aug. 21, 1923, one male and one female, Aug. 30, 1923, in the collection of J. R. Malloch. One male, Fort Andrews, Ohio, June 10-12, 1902; one male, Vinton, Ohio, June 5-12, 1900; two females, Cincinnati, Ohio; two from Hinkley, Medina County, Ohio; one from Wauseon, Ohio, Sept. 2, 1902; in the collection of Proi. J.S. Hine. One male, Dead Run, Fairfax County, 
Virginia, June 16 (N. Banks); one female, Falls Church, Virginia, Sept. 10 (N. Banks); and one male, North Wilbraham, Massachusetts, Aug. 15, 1916 (D. A. Ricker); all in collection of Nathan Banks. Two males and one female, Chain Bridge, Virginia, Aug. 12, 1923 (H. W. Allen); one male and one female, Great Falls, Virginia; in my collection.

Type and allotype.-Cat. No. 28156 U.S.N.M., Chain Bridge, Virginia, August 12 (male type) (H. W. Allen); July 6 (allotype) (J. M. Aldrich).

The present known range of this species is from Massachusetts, Indiana, and eastern Kansas southward to Virginia and Louisiana. The writer has found the adults common on the high rocky bluffs of the Potomac River, where they may be found on low foliage, in sunlit spots, in open deciduous forest. In the same region they are not commonly encountered in open fields, either on vegetation or denuded ground. However, one specimen from Massachusetts, collected by D. A. Ricker, is labeled "clover." Another specimen examined, collected by Doctor Aldrich is labeled "prey of Laphria canis." The host relationships of M. sinipalpis are not known.

\section{METOPIA PERPENDICULARIS Van der Wulp}

-Metopia perpendicularis VAN DeR WulP, Biol. Cent. Amer., Dipt. vol. 2, p. $115,1891$.

The type, a female specimen from Mexico in the British Museum, not seen by me. From the description and figures, it is recognized as a species of Metopia distinct from the others described in this paper. It appears to resemble, rather closely, campestris and inermis, from which it is readily distinguished by the perpendicular hind cross vein and the more prominent front.

\section{Genus SPHENOMETOPA Townsend.}

Sphenometopa Townsend, Smithsonian Misc. Coll., vol. 51, p. 64, 1908. Genotype, Araba nebulosa Coquillett.-Coquillett, Proc. U. S. Nat. Mus., vol. 37, p. 607, 1910.

Eumetopia Brauer and Bergenstamm, Zweifl. d. Kaiserl. Mus., vol. 56, p. 114, 1889. Preoccupied in Rhyncophora.

Euaraba Townsend, Proc. Biol. Soc. Washington, vol. 28, p. 20, 1915. Genotype, Araba tergata Coquillett.

Arabiopsis Townsend, Can. Ent., vol. 47, p. 285, 1915. Genotype, Arabiopsis cocklei Townsend.

Araba of Authors not Robineau-Desvoidy, Coquillett, U. S. Bur. Ent., Tech. Ser., no. 7, p. 127, 1897.-Bezzi and Stein, Kat. Pal. Dipt., vol. 3, p. 508, 1907.-Adams, in Williston's Manual of N. Amer. Dipt., p. 375, 1908.

The genus Araba was proposed by Robineau-Desvoidy in 1830, Myodaires (p. 127), to include several species, no genotype being designated. In 1863, Diptères des Environs de Paris (vol. 2, p. 88), 
he slightly modified the name Araba to Arabella, for the sake of euphony, and designated Tachina argyrocephata Meigen, the third of the originally included species, as the genotype. Since argyrocephala is a synonym of leucocephala, the genotype of Metopia, Araba becomes a synonym of Metopia. This synonomy, rather vaguely defined by Coquillett, in his 1910 paper on type species, was recently clearly pointed out to me by Dr. J. M. Aldrich, in correspondence. While the type of Araba is unquestionably a Metopia, certain species formerly placed in this genus are certainly distinct from Metopia. Eumetopia, proposed by Brauer and Bergenstamm in 1899, is preoccupied. Sphenometopa, proposed by Townsend in 1908, for Araba nebutosa Coquillett, appears to be the earliest valid name. After an examination of types, I am of the opinion that Euaraba and Arabiopsis are congeneric with Sphenometopa. The European fastuosa Meigen also belongs here.

The characters of this genus based on a study of the European species, fastuosa Meigen and three North American species are as follows. Front wider in female than in male; frontal vitta much wider than parafrontals, setulose or hairy on the sides, between the frontal rows and below the ocellar triangle; ocellar bristles very weak or absent; a single frontal row on either side of frontal vitta, descending at least to middle of second antennal joint; orbital bristles present in both sexes; antennae extending nearly to vibrissae; penultimate joint of arista not more than twice as long as wide; facial ridges with strong macrochaetae extending more than half way from vibrissae to base of antennae; head length at vibrissae much less than at base of antennae; parafacials without macrochaetae; proboscis stout and distinctly shorter than head height; no pale hairs at the sides or back of the oral cavity. Thorax with three strong postsutural dorsocentral bristles and two sternopleurals. Intermediate abdominal segments without even, pollinose basal bands. Male genitalia (pl. 1, fig. 4) small, and in repose, scarcely visible in profile view; female with the usual retracted nonpiercing larvipositor. Wings hyaline or with smoky spots; apical cell open and ending far before extreme tip of wing; fourth vein with fold at the bend; last section of fifth vein much less than half as long as preceding section; costal spine absent or minute; only the third vein bristly, and this at most with three to four bristles near its base. Front pulvilli of both sexes less than half as long as the last tarsal joint; basitarsus of fore leg of male (pl. 3, fig. 18) sometimes structurally modified or ornamented; middle tibia with a single bristle on outer front side near middle; hind tibia on outside with a row of uneven bristles extending from base to apex with one bristle near the middle much the largest. 
KEY TO NORTH AMERICAN SPECIES OF SPHENOMETOPA

1. Front at base of antennae as wide as either eye Front at base of antenna distinctly narrower than either eye; section of fourth vein beyond the bend nearly straight; parafrontal rows not widely divergent below; male with conspicuous smoky spots in the wing, and with the basitarsus of the foreleg expanded into a large triangular seg-

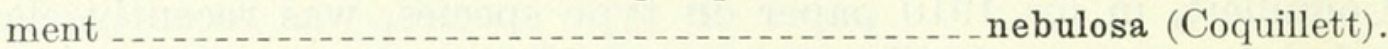

2. Middle tibia with only a single bristle on outer hind side near middle; arista thickened to apex $-4$.

Middle tibia on outer hind side near the middle with several bristles; arista thickened on basal three-fifths

3. Abdomen with a broad black median vitta bordered with white pollen; basitarsus of foreleg bearing a conspicuous tuft of black hair.

(male) cocklei (Townsend).

Abdomen golden pollinose, with a pair of small bronzed spots on the sides of the first three segments; basitarsus of foreleg without ornamentation

(female) cocklei (Townsend).

4. Front, including the vitta, conspicuously silvery; thorax black and but thinly whitish pollinose _...................... (male) tergata (Coquillett).

Front and thorax densely golden pollinose, frontal vitta brown.

(female) tergata (Coquillett).

\section{SPHENOMETOPA TERGATA (Coquillett)}

Araba tergata Coquillett, Journ. New York Ent. Soc., vol. 3, p. 103, 1895; U. S. Bur. Ent., Tech. Ser., No. 7, p. 127, 1897.-Sмгтн, Ins. of New Jersey, p. 782, 1909.-Thompson, Recherches sur les Diptéres Parasites, Paris Edition du Bull. Biol. de la France et de la Belgique, pp. 107-108, figs. XxxII, 116, 1921.

Euaraba grisea Robineau-Desvoidy, Townsend, Insecutor Ins. Menst., No. 6, p. 182,1918 (in error).

In this species the front is somewhat wider than in the other two North American forms, being 0.36, 0.36, 0.36, 0.37, 0.37, with an average of 0.364 of the head width in five males, and $0.41,0.44,0.44$, $0.44,0.46$, with average of 0.438 in five females. In the male, the inner orbits are narrower at vertex than at base of antennae; the front, including the vitta, and the face are brilliant silvery pollinose; frontal vitta with barrel-shaped outline; frontal rows suddenly divergent below; two proclinate orbitals; arista short plumose, thickened almost to apex, penuitimate joint not longer than broad. Mesonotum in front of suture, and scutellum, dull black, while pleura, mesonotum behind the suture and apex of scutellum, are silvery pollinose; scutellum with two pairs of strong marginal bristles, the apicals wanting. Abdomen shining black, with silvery pollen at the lateral basal parts of the first three segments, the fourth with a band of white pollen on basal half; first segment without bristles, intermediate segments with strong median marginals, and fourth with a marginal row. Inner forceps of male genitalia (pl. 1, fig. 4) slightly divergent from near base, somewhat flattended at base, tapering gradually to slender tips, round in cross section; outer for- 
ceps shorter and much stouter than the inner, with broadly rounded, spatulate tips; penis with delicate membranous hood, supported by a heavily chitinized rod which is $\mathrm{Y}$-shaped in profile, one arm of the "Y" encircling the basal part of the hood anteriorly; claspers small and sharply pointed. Wings hyaline; apical cell narrowly open; section of fourth vein beyond the bend strongly arcuate; one to three bristles at base of third vein. The female differs strikingly in appearance from the male, having the frontal vitta brown and not barrel shaped in outline; a row of one reclinate and four $t$ five proclinate orbital bristles, of which the anterior pairs are much the largest. Thorax uniformly gray pollinose with two obscure narrow median vittae; scutellum also pollinose with obscure bronzed spots at the sides; on the white pollinose abdomen, the first three segments bear rows of sharply-defined, round, black spots, which are sometimes coalesced in an apical band.

\section{Length, 3.5 to $5.5 \mathrm{~mm}$.}

\section{Type--Male, Cat. No. 3631, U.S.N.M.}

The following material has been examined. Type, a male from Algonquin, Illinois (W. A. Nason); two other specimens from Algonquin bearing Coquillett's name and one specimens from Altadena, California, presumably of the type series; one, Franconia, New Hampshire (Mrs. Slosson); three, Lafayette, Indiana, two of which labeled "on log"'(J. M. Aldrich); fourteen, Lewiston, and one, Moscow, Idaho (J. M. Aldrich); one, Boulder, Colorado; one Colorado (Coquillett); one, Animas Park, New Mexico, 6,500 feet; all in the collection of the National Museum. One Amherst, Massachusetts, and twelve, Columbus, Ohio, taken largely from rocks in gravel pits and dumps, in the collection of the writer. Specimens from several places in Massachusetts, and from Hampton, New Hampshire, in the collection of the Boston Natural History Society. Specimens from New Jersey in the collection of Dr. C. W. Johnson. Several specimens from Massachusetts and Pennsylvania in the collection of the Museum of Comparative Zoology at Cambridge, Massachusetts.

Thompson ${ }^{34}$ finds that the female reproductive apparatus of this species resembles that of the other Miltogramminae studied. In the first instar maggot, the usual longitudinal ribs or corrugations of the cuticula are lacking, and not only the anterior borders but the entire surface of the segments are interspersed with microscopic colorless scales, which under high magnification are seen to be pointed and directed backwards. The buccopharyngeal apparatus is of the same type as that found in Metopia, Miltogramma, and other nearly related genera. Grooves in the pharynx are wanting.

${ }^{34}$ Paris Edition du Bull. Biol. de la France et de la Belgique, Recherches sur les Diptères Parasites, p. $107,1921$. 
The known range of this species is from New Hampshire and Idaho to New Jersey, Pennsylvania, Indiana, Colorado, and New Mexico. In Massachusetts and Ohio it is known to occur in large numbers about gravel pits, railroad and highway cuts and fills which are denuded or only scantily covered with vegetation, and strewn with rocks and cobblestones. The adults may be seen in such places, darting about just above the surface of the ground in characteristic zigzag flight, and alighting from time to time on rocks or small stones. Adults have not been taken on flowers. The host relationships of this species are not known.

\section{SPHENOMETOPA NEBULOSA (Coquillett)}

Araba nebulosa Coquillett, Canad. Ent., vol. 34, p. 200, 1902.

Sphenometopa nebulosa Townsend, Smithsonian Misc. Colls., vol. 51, p. $64,1908$.

Male with the front rather narrow, being $0.25,0.27,0.31$, with an average of 0.28 of head width; front much narrower at base of antennae than at vertex; frontal rows not widely divergent below base of antennae; parafrontals with row of one reclinate and two proclinate orbital bristles back of which is a tuft of erect bristly hairs; arista thickened on basal two-fifths, the penultimate joint distinctly shorter than twice the width. Thorax gray pollinose, obscurely five vittate; scutellum with three pairs of marginal bristles, of which the intermediate pair is much the largest; abdomen fiattened dorsoventrally, truncate at apex, black overlaid with dense white pollen, with three conspicuous black spots on dorsum of each one of the first three segments sometimes coalescing apically; intermediate segments, and usually the first with a median marginal pair of bristles, fourth segment with a marginal row. Wings hyaline with small but quite distinct smoky spots at the apex of second vein, the bend of the fourth, the apex of the first, beyond the small cross vein and at the angle of the fifth vein and the hind cross vein, a small niveous spot at extreme tip of wing; apical cell narrowly open; last section of fourth vein straight from bend to margin of wing; one small bristle at base of third vein. Basitarsus of fore leg (pl. 3, fig. 18) conspicuously expanded ventrally into a triangular segment having pale hairs on its ventral margin. The female closely resembles the male, but its front is wider, being 0.32 and 0.34 with an average of 0.33 of head width in two specimens measured; the third antennal joint is slightly shorter, the basitarsus of the fore leg is not modified, and the infuscated spots on the wings are less conspicuous.

Length, 5.0 to $5.5 \mathrm{~mm}$.

Material examined: type, a male from Sierra Madra, Chihuahua, Mexico, and another male from the same locality and apparently of the type series (C. H. T. Townsend); one male and one female, Florrisant, Colorado, labeled "on sand" (S. A. Rohwer); one male 
and one female, Animas Pass, New Mexico, 6,500 feet; all in the collection of the National Museum.

This species is a Rocky Mountain and Sierra Madra form concerning the biology of which very little is known. Townsend states that the Sierra Madra specimens were taken in the pine zone at about 7,000 to 7,500 feet elevation. The host relationships are not known.

Two additional males collected July 25, 1925, at Summit, Montana, by J. M. Aldrich; they were found at the edge of a cascade on smooth, wet rocks in the sun. Altitude about 5,000 feet.

\section{SPHENOMETOPA COCKLEI (Townsend)}

Arabiopsis cocklei Townsend, Canad. Ent., vol. 47, p. 286, 1915.

Male.-Front at narrowest 0.34 of head width (measurements of three $0.33,0.33$ and 0.35 ) ; inner orbits much narrower at vertex than at base of antennae, with pronounced concavity to accommodate bulge in sides of front, and divergent to bucca; frontal vitta barrelshaped in outline, at middle three to four times width of parafrontals, concolorous with parafrontals which are gray pollinose, a dark reflecting spot below the ocellar triangle on each side of the vitta; the proclinate ocellar bristles scarcely differentiated from the surrounding hairs; a row of about four proclinate and two reclinate orbital bristles of variable sizes; posterior part of front bare of bristly hairs; vibrissae scarcely differentiated from surrounding bristles, inserted slightly above oral margin; facial ridges divergent, with strong macrochaetae on lowest two-thirds; antenna black, extending nearly to vibrissae, third joint three to three and onehalf times as long as second; arista thickened on basal three-fifths, penultimate joint nearly twice as long as wide; in profile, width of bucca slightly greater than that of parafacials and equals one-third eye height, front projects one-half horizontal diameter of eye; parafacials setulose on upper half; bucca densely black setulose; palpi black, filiform. Thorax blue-white pollinose over dull black, with two narrow median vittae and densely covered with long bristly hairs; scutellum with three pairs of marginal bristles of which the intermediates are the longest; strong preapicals present. Abdomen strongly flattened, truncate at apex; black, the sides densely blue-white pollinose, middle of dorsum with a broad black vitta which becomes narrower towards apex, a single pair of small bronzed spots, lateral to the vitta, on each of the intermediate segments; first two segments with two to four long median marginal bristles and one or two smaller laterals; third and fourth segments each with a marginal row. Wings slightly infuscated towards base; apical cell narrowly open at tip; last section of fifth vein not nearly half as long as preceding section; two to three bristly hairs at the base of the third vein. Legs black; basitarsus of fore leg with con- 
spicuous tuft of black hairs on the heel and fringing the outside; middle tibia with the usual single bristle on the outer front side near the middle and a row of four to five uneven bristles on the outer hind side.

Female.-Front at narrowest 0.43 of the head width (measurements of two 0.42 and 0.44 respectively); front somewhat more golden pollinose, without the conspicuous dark reflections; two rather strong proclinate orbitals differentiated from the surrounding bristles and bristly hairs on the parafrontals; vibrissae at least the length of the second antennal joint above the front edge of the oral margin; third antennal joint equals two and one-half times length of second; in profile, bucca equals one-third eye height. Thorax densely golden bronze pollinose; sparsely short setulose. Abdomen black, densely covered with golden bronze pollen, without a broad black median vitta; a pair of small but distinct bronzed spots towards the sides on the first three segments, fourth pollinose to apex. Front basitarsus without modifications. Otherwise except for usual differences of genitalia, like the male.

Length 5.0 to $6.0 \mathrm{~mm}$.

Type.-Male, Cat. No. 19554. U.S.N.M.

Redescribed from the type, a male specimen from London Hill Mine, Bear Lake, British Columbia, 7,000 feet, July 21, 1903 (J. W. Cockle); two females and one male, Marshall Pass, Colorado, July 18, 1908, 10,856 feet; one female, Tennessee Pass, Colorado, 10,240 feet (J. M. Aldrich); all in the collection of the National Museum.

This Rocky Mountain alpine form has as yet not been collected below 7,000 feet elevation. Little is known of its habits and nothing concerning the host relationships.

\section{Genus PHROSINELLA Robineau-Desvoidy}

Phrosinella Robineau-Desvoidy, Dipt. Envr. Paris, vol. 2, p. 83, 1863 Genotype (Tachina) nasuta Meigen from Europe.

Phrosina Robineau-Desvoidy, Dipt. Envr. Paris, vol. 2, p. 101, 1863. According to Bezzi and Stein, Kat. Pal. Dipt., vol. 3, p. 513, 1907, preoccupied, and the genotype argyrina Robineau-Desvoidy equals nasuta which is the genotype of Phrosinella.

Euhilarella Townsend, Proc. Biol. Soc. Wash., vol. 28, p. 22, 1915. Genotype Hilarella fulvicornis Coquillett.

Inner orbits narrowest at base of antennae, diverging moderately toward vertex and bucca but distinctly pinched in at the lower corners of the eyes; front distinctly narrower in males than in females: frontal vitta strongly divergent posteriorly, at middle wider than parafrontals, usually with distinct wrinkles radiating from base of antennae; a single row of frontal bristles which extends below base of second antennal joint and is suddenly divergent below; orbital bristles, usually one reclinate and two proclinate, present in both 
sexes; one pair of proclinate ocellars; vibrissae located near front edge of oral margin, not noticeably approximated; facial ridges with a few scattered hairs on the lowest fourth or less; lunule conspicuous, shield shaped, situated in a deep indentation of the frontal vitta; antennae extending nearly to level of vibrissae; plumosity of arista not longer than its greatest diameter, penultimate joint scarcely longer than wide; in profile, head length at oral margin is much less than at base of antennae, epistoma not prominent; parafacials bare or beset with black bristly hairs; bucca and back of head with black bristly hairs except for sparse white hairs at sides and back of oral cavity; proboscis stout, much shorter than head height, labella fleshy; palpi normal; eyes with the facets at extreme front but slightly larger than those at the sides. Thorax with three strong postsutural dorsocentral bristles and two strong sternopleurals; scutellum with three marginal pairs. Abdomen elongate conical; intermediate segments each with a row of three large spots which are sometimes confluent posteriorly; the basal pollinose band, when present, is always scalloped on the posterior margin as if formed by the coalescing of large spots. Genitalia of male (pl. 1, fig. 6) in repose, scarcely protruding; of female, nonpiercing and retracted. Wings with apical cell open; fourth vein at bend with a distinct fold; last section of fifth vein varies from nearly half to slightly more than half the length of preceding section; third vein with row of small bristles extending more than half the distance from base to small cross vein; a strong costal spine usually present. Pulvilli of both sexes rather short; front tarsus of male (pl. 3, figs. 15, 16) usually ornamented with a peculiar brush of long hairs; of female (pl. 3, fig. 17) strongly flattened; middle tibia with one bristle on outer front side near the middle; hind tibia, on outside with a complete uneven row of bristles.

After study of the North American material and comparison with European specimens of the genotype nasuta, it becomes evident that the common species long recognized as Hilarella fulvicornis Coquillett and three closely related species described in this paper are much more closely allied morphologically to nasuta, than to hitarella, the genotype of Hilarella. The genotype of Phrosina not seen and its present location not known to me. The genotype fulvicornis of Euhitarella has been compared with specimens of nasuta loaned by Professor Bezzi. From the genus Eumacronychia, with which it has been confused, Phrosinella may be distinguished by the possession of spots instead of even bands on the abdomen, and in having the elongate lunule conspicuously imbedded in a sinus of the frontal vitta, the fore tarsus of the male usually bearing a conspicuous tuft of long bristly hairs, and that of the female without tufts of bristly hairs but usually strongly flattened. 
Phrosinella is holaretic in distribution. The species in North America, so far as known, are distinct from those of Europe, and have not been taken outside of the United States. There are four Nearctic species, each with a somewhat restricted range.

The flies of this genus, as far as known, occupy the ground-subterranean stratum, being found in the adult stage largely on barren ground, in and about the holes of burrowing Hymenoptera, rarely on low foliage. They are not commonly attracted to flowers, but at least one species frequently feeds on honeydew. It is believed that they are biologically superimposed upon fossorial Hymenoptera, but reliable rearing records are lacking. Dissections of one species indicate that they deposit large, active maggots. The female of this species has also been observed digging a pit in the sand near the burrows of fossorial Hymenoptera, for which its flattened fore tarsi are admirably adapted. Larvae were deposited in the pit. It seems probable that from this point, they burrow through the soil to the cell of their host, a form of activity which may be correlated with the presence of a conspicuous spiniferous foot on the ventral part of the last segment of the first instar maggots. Pupation takes place in the soil, apparently not far from the cell of the host.

KEY TO NORTH AMERICAN SPECIES OF PHROSINELLA

1. Third antennal joint black

Third antennal joint bright yellow, rarely overlaid with blackish tomentum.

fulvicornis (Coquillett).

2. Third abdominal segment with black polished apex which is devoid of pollen_3.

Third abdominal segment pollinose to apex, at most with small black spots about the marginal bristles; wings distinctly infuscated; thorax and abdomen grayish pollinose with brownish tinge _........_fumosa, new species.

3. Front distinctly hairy, many bristly hairs on frontal vitta between frontal rows; males with conspicuous tuft of hairs on underside of second tarsal joint of fore leg, third tarsal joint much thicker and shorter than the fourth.

pilosifrons, new species.

Front almost destitute of hairs, vitta bare; males with conspicuous tuft of hairs on outside of second tarsal joint, third joint scarcely wider than the fourth aldrichi, new species.

\section{PHROSINELLA FULVICORNIS (Coquillett)}

Gymnoprosopa fulvicornis Coquillett, Journ. New York Ent. Soc., vol. 3, p. 106,1895 .

Hilarella fulvicornis Coquillemt, U. S. Bur. Ent., Tech. Ser., No. 7, pp. 17, 128, 1897.- Smith, Ins. of New Jersey, p. 782, 1909.-Cole and Lovett, Proc. Cal. Acad. Sci., vol. 11, p. 303, 1921.-Brimley, Ent. News, vol. 33, p. 23, 1922 .

Euhilarella fulvicornis Townsend, Proc. Biol. Soc. Wash., vol. 28, p. 22, 1915. Phrosinella fulvicornis Allen, Occas. Pap. Bost. Soc. Nat. Hist., vol. 5, p. 92,1924 .

Male.-Front at narrowest 0.35 of head width (measurements of five, $0.30,0.35,0.35,0.37,0.39)$; front, including the vitta which is scarcely distinguishable, white or sometimes golden pollinose; vitta 
divergent posteriorly, at level of lowest orbitals, three to four times width of either parafrontal; frontal row of seven to nine bristles; facial ridges with but two to three small bristles inserted directly above vibrissae; antennae red, extending about five-sixths distance to vibrassae, third joint three to four times length of second; arista thickened on basal three-fifths, penultimate joint almost twice its width; parafacials bare or sparsely beset with black bristly hairs, distinctly narrowest at the lower corner of eye; in profile, bucca equals one-sixth eye height; palpi yellow. Thorax and scutellum densely gray pollinose, without distinct vittae; intermediate pair of marginal scutellar bristles larger than the other two equal pairs; small preapicals present. Abdomen gray to golden pollinose, first segment somewhat more thinly so, with a median polished black spot, intermediate segments each with one to three triangular black spots, in third sometimes coalescing to form a continuous apical band, fourth polished black with pollinose band on basal half; one lateral and one median marginal pair of bristles on the first and the second segments, third and fourth segments with median marginal rows of about ten. Genitalia (pl. 1, fig. 6) as in fumosa excepting the claspers, which are smaller. Wings hyaline; often slightly clouded in middle from discal cell to costal margin; section of fourth vein beyond bend strongly arcuate, distance from bend to hind cross-vein about half length of preceding section; last section of fifth vein much less than half the preceding section. Legs black; second joint of fore tarsus bearing on ventral side a conspicuous tuft of long bristly hairs not horizontally flattened or cupped when viewed from above; last three tarsal joints much reduced in size and arched above the brush-like tuft, third segment distinctly broader than the two apical joints which are slenderly elongate; hind tibia with outside row of about nine uneven bristles.

Female.-Front at narrowest 0.44 of head width (average of fifteen which range from 0.39 to 0.45 ) ; third joint of antenna two and onehalf to three and one-half times length of second. Fore tarsus (pl. 3, fig. 17) broadly flattened but not reduced in size, and lacking tuft of long bristles. Otherwise save for usual difference in genitalia, like the male.

Length, 4.0 to $7.5 \mathrm{~mm}$.

Type.-Male, Cat.No. 3633, U.S.N.M., from Avalon, New Jersey, (Johnson).

These notes are based on an examination of the type and a long series of both sexes in the collections of the National Museum, Boston Society of Natural History, Museum of Comparative Zoology of Cambridge, Massachusetts, Massachusetts Agricultural College, Dr. C. W. Johnson, Nathan Banks, Prof. J. S. Hine, and the writer, including specimens from the following localities: New Hampshire; 
Sunderland, West Springfield, Provincetown, Horseneck Beach, and Martha's Vineyard, Massachusetts; Avalon, Anglesea, Clementon, and Pemberton, New Jersey; Chesapeake Beach and Beltsville, Maryland; Brookland, District of Columbia; Columbus, Ohio (H. W. A.); Ira, Summit County, Ohio (J. S. Hine); Lafayette, Indiana (J. M. Aldrich), (E. W. Stafford); Michigan City, Indiana (J. M. Aldrich); Algonquin, Illinois (Nason); Great Falls, Virginia (J. M. Aldrich); Flomaton, Alabama (J. M. Aldrich); Mobile, Alabama (H. W. A.) ; Holly Springs, Mississippi (F. W. Mally); West Point, Mississippi (F. M. Hull); Starkville, Meridian, Agricultural and Mechanical College, Ocean Springs, Moss Point, and Gulfport, Mississippi (H. W. A.); White Springs, Florida (C. H. T. Townsend); Milwaukee, Wisconsin (S. Graenicher); Mandan, North Dakota (J. M. Aldrich); Powderville, Montana; Florissant, Colorado (S. A. Rohwer); one Brookland, District of Columbia, labeled "Parker number 50." In one specimen in C. W. Johnson's collection from Horseneck Beach, Massachusetts, the third antennal joint has a blackish cast, over yellow. This is exceptional since most specimens have bright yellow antennae. Although Coquillett states that in this species the third joint is sometimes black, I am inclined to believe, after careful study of a long series, that specimens in which this joint is black without traces of yellow belong elsewhere.

Three dried specimens of females have been dissected, and while such material is unsatisfactory, some definite information has been obtained on the nature of reproduction in this species. The uterus in each case was found filled with large naked maggots, all in the same stage of development. Fourteen were counted in one and eight in another. The larvipositor was found to consist of small, weak, nonpiercing valves located at the tip of an extensile apparatus of three segments, in repose telescoped within the abdomen.

The first instar maggot from the uterus was found to possess the following characters. The cuticula of each segment with several encircling rows of microscopic, transparent, flattened scales followed by a band of transparent, longitudinal ribs or furrows, giving to the lower part of the segment a corrugated appearance; ventral part of last segment provided with fleshy foot, densely beset with stout, sharp, brown spines; no other brown spinose areas occur. Buccopharyngeal apparatus (pl. 5, fig. 29) consists of the usual parts, in which the median hook is longer and about equal in mass to the remainder of the apparatus; the long, slender median hook tapers gradually to a strong, slender point, without denticles on the ventral surface; lateral hooks apparently fused at the tip to the median hook; ventral part of the intermediate $\mathrm{H}$-piece much reduced and not barblike in profile view; upper and lower wings of the basal piece 
approximated so that the height of this sclerite is distinctly less than length of its wings.

I have examined one puparium, finding the anal segment equipped with several rows of sharply pointed, microscopic spines, and the posterior spiracles located in a distinct pit (pl. 5, fig. 35) and separated by a distance equal to diameter of one spiracle.

P. fulvicornis is common in the United States east of the Mississippi River and is also known to occur in Colorado. It has been reported from Oregon, but this record will very likely be found to refer to $P$. pilosifrons or some other western species.

The adults occur on barren, sandy ditch bottoms, over sand dunes, on sand bars, barren places in open pastures, on stone-strewn country roads and on the upper marine beach. In such places they are frequently associated with several species of Senotainia and allied genera as well as various species of fossorial Hymenoptera. They have never been taken on flowers or rank vegetation. The adults dart about just above the surface of the ground in characteristic zigzag flight very closely resembling that of the small Larridae from which they are not readily distinguished until they alight on the ground.

One adult was captured as it emerged from the burrow of a digger wasp, presumably one of the small Bembicidae which inhabit the beach in great numbers, at Mobile, Alabama. Another specimen was reared from a puparium taken at Columbus, Ohio, where it was found in damp sand, two or three inches from the surface and in close proximity to nests of Bembix spinolae. The writer formed the opinion from the conditions under which the puparium was found that the maggot had come to maturity in the nest of the Bembicid and had crawled a short distance away into the loose sand to pupate, but it is by no means certain that $B$. spinolae was the host of this individual, since the tunnels of many small Larridae were present in the same sand bed in close proximity to the nests of the Bembicidae. Prof. J. B. Parker has made a very interesting observation on a fly captured on the sand where a number of different species of wasps were nesting, near Washington, D. C. (Parker note, No. 50). He says that this species has the habit of wandering about over the sand apparently engaged in smelling, and then in digging in the sand. The specimen captured dug quite a pit at the entrance of a burrow of Oxybelus quadrinotatus Say, and then went through the motions of oviposition in the pit. Professor Parker's observation is the first to indicate the probable use to which the strongly flattened fore tarsi of the females of North American species of Phrosinella have become adapted. Coquillet ${ }^{35}$ records the rearing of an adult

${ }^{86}$ U. S. Bur. Ent., Tech. Ser., No. 7, p. 17, 1897. 
from a puparium found among eggs of Acrididae. This association was probably accidental.

PHROSINELLA FUMOSA, new species

Male.-Front at narrowest 0.42 of head width (measurements of four $0.41,0.42,0.43,0.43)$; front golden pollinose, including the vitta which is scarcely distinguishable from the parafrontals; vitta diverging slighlty towards the rear, at level of lowest orbitals, three times width of either parafrontal; ten to twelve bristles in the frontal row; parafrontals sparsely beset with black bristly hairs which extend downward to apex of second antennal joint, and invade the vitta to the extent of several hairs on each side between the frontal rows; facial ridges with two to four small bristly hairs not extending above the lowest fifth; antennae black, extending about seven-eighths distance to vibrissae, apex of second joint rufous, third joint four times length of second; arista thickened on basal three-fifths, length of penultimate joint one and one-half times width; parafacials white pollinose, bare, narrowest at lower corner of eye; in profile, bucca equals one-six th eye height. Thorax densely gray pollinose with bronze reflections; two narrow vittae between the presutural dorsocentrals, ending at transverse suture; scutellum densely gray pollinose, with conspicuous black spot on each side near base; intermediate marginal bristles larger than the other two equal pairs; preapicals lacking. Abdomen densely gray pollinose, distinctly tinged with bronze; first three segments with one to three obscure spots near the apices, fourth with apical margin subshining black; first and second segments each with a single lateral and one median marginal pair of bristles; third and fourth with marginal rows of ten to twelve. Genitalia black; inner forceps elongate, tapering gradually to slender tips, somewhat flattened laterally, in profile, with a pronounced concavity on the outer margin just beyond the base, and curving slightly forward at the tips; outer forceps yellow, nearly as long and somewhat broader at the tips than inner forceps; penis with membranous hood tapering from a bulbous base to a slender erect process at the posterior apical corner, and bearing anteriorly rather coarse conical spines; posterior claspers with a small bristle. Wings subhyaline, with the area limited by small cross-vein, hind cross-vein, apex of fourth and the costal margin, infuscated; hind cross-vein and last two sections of fourth vein with clouded margins; section of fourth vein beyond bend strongly arcuate, frequently bent backward to form an acute angle with preceding section; last section of fifth vein scarcely more than one-third preceding section. Legs black; second joint of fore tarsus with a ventral tuft of long upcurved bristles, cupped when viewed from above; last three joints much reduced and arched above the tuft of bristles, the third broad and 
short, the fourth and fifth slenderly elongate; hind tibia with outside row of about eight uneven bristles.

Female.--Front at narrowest 0.47 of head width (measurements of five $0.45,0.47,0.48,0.48,0.48)$; third antennal joint three to four times length of second. Last four joints of fore tarsus moderately flattened, not reduced, and lacking tuft of long bristles. Otherwise, except for usual differences of genitalia, like the male.

Length. 7.0 to $9.5 \mathrm{~mm}$.

Type.-Male, Falls Church, Virginia, July 11, in the collection of Nathan Banks.

Allotype.-Female, Cat. No. 28157, U.S.N.M., Falls Church, Virginia, July 21 (C. T. Greene).

Described from the following: In the collection of the National Museum; one female from Massachusetts labeled "Coquillett collection"; four females from Falls Church, Virginia, July 21 (C. T. Greene). In the collection of C. W. Johnson, two females from Westport Factory, Massachusetts, July 31, 1913; one male from Delaware Water Gap, New Jersey, July 13. In J. R. Malloch's collection, one male and one female from Beltsville, Maryland, July 9, 1916. In Nathan Banks' collection, four males and four females from Falls Church, Virginia, July 4 to 25 (N. Banks), one taken feeding on honeydew on tulip tree; one male and one female, Great Falls, Virginia, June 29 and July 8 (N. Banks).

The present known range of fumosa is confined to the region east of the Appalachian Mountains from southern Massachusetts to eastern Virginia. In the valley of the Potomac, it has been found hovering low over stone-strewn roads through hilly upland forest, and on honeydew-coated foliage beneath the tulip tree, Liriodendron tulipifera. The hosts of fumosa are not known.

PHROSINELLA ALDRICHI, new species

Male.-Front at narrowest 0.343 of head width (measurements of three $0.33,0.34,0.36)$; front including vitta, all of face and bucca white pollinose; vitta at level of lowest orbitals four times width of either parafrontal; frontal row of eight to ten bristles, extending to middle of second antennal joint; only a few bristly hairs on front outside frontal rows; facial ridges with but one or two hairs above vibrissae; antennae black, extending five-sixths the distance to vibrissae, third joint four times length of second; arista thickened on basal three-fifths; parafacials bare, or sometimes sparsely black setulose, conspicuously narrowed at the lower corner of the eye; in profile, bucca equals one-eighth the eye height; proboscis scarcely one-half the head height; palpi subclavate, yellow. Thorax gray pollinose over black, with five obscure vittae of which the three median ones are much narrower, extending only to the transverse 
suture; the intermediate pair of marginal scutellar bristles are larger than the two other equal pairs; small preapicals usually present. Abdomen black, the last three segments polished on the broad apices, white pollinose at the base, the pollinose bases indented from behind by three to five triangular spots; first and second segments each with a pair of strong median marginal bristles, the last two with uninterrupted rows of ten to twelve. Wings hyaline; section of fourth vein from bend to hind cross vein equals one-half the preceding section; last section of fifth vein nearly one-half preceding section. Legs black; fore tarsus (pl. 3, fig. 16) with its second joint enlarged and bearing a dense tuft of long bristly hairs on the outside, third and fourth joints strongly flattened, slightly longer than broad, fifth joint elongate and slender; hind tibia on outside with row of about seven uneven bristles extending from base to apex.

Female. - Front at narrowest 0.43 of head width (measurements of five $0.40,0.41,0.42,0.45,0.46$ ) ; frontal vitta deeply golden pollinose, two to three times width of parafrontals at lowest orbital; third antennal joint two and one-half to three times the second. Last four joints of the fore tarsus flattened, but not reduced in size, second joint without conspicuous tuit of long hairs. Otherwise, except for usual differences in genitalia, like the male.

Length, 4.0 to $5.5 \mathrm{~mm}$.

Type and allotype--Cat. No. 28158, U.S.N.M., Lewiston, Idaho, male type collected Sept. 25, 1909; no date given for allotype.

Range.-Idaho, Nevada, California, Washington, British Columbia. Host relationships.-Unknown.

Described from the following: two males and three females from Lewiston, Idaho; two females from Boise, Idaho; one female from Walker Lake, Nevada, July 25, 1911; one male, San Joaquin River, Newman, California. All the preceding collected by Doctor Aldrich, in whose honor the species is named; these and one male from Pasadena, California, are all in the National Museum. One female, Oliver, British Columbia, 7-vi-1923 (C. B. Garrett), in the Canadian National collection. One female, Lake Paha, Washington, 7-20-'20 (R. C. Shannon) in Shannon's collection.

PHROSINELLA PILOSIFRONS, new species

Male.-Front at narrowest 0.36 of the head width (measurements of three $0.34,0.34$ and 0.39$)$; front, all of the face and the bucca white pollinose; vitta distinguishable as a gray pollinose band, somewhat wrinkled, moderately divergent posteriorly, at level of lowest orbitals twice as wide as either parafrontal; the single frontal row inserted at some distance from edge of vitta, and bearing thirteen to fifteen bristles; one or two bristles outside the frontal row, in the angle of divergence which it forms near base of antennae; parafrontals 
thickly beset with slender erect hairs which are most dense at or below level of lowest ocellus, where they invade the vitta and form there a distinct fringe on both sides between the frontal rows; vibrissae level with front edge of oral margin; facial ridges with small bristly hairs on lowest fifth; antennae extending five-sixths the distance to vibrissae, first two joints red, third joint black, four times length of second; arista thickened on basal three-fourths, penultimate joint slightly longer than broad; parafacials hairy to near tip of antennae, distinctly narrowest at lower corner of eye; in profile, bucca equals one-sixth eye height; palpi yellow. Thorax black, subshining, sparsely gray pollinose; obscurely five-vittate, inner three vittae much narrower, none extending beyond transverse suture; notum densely pilose with fine erect black hairs; scutellum densely gray pollnose at tip, black subshining at base, the intermediate pair of marginal bristles distinctly larger than the other two equal pairs, small preapicals differentiated. Abdomen gray pollinose over black; pollinose area of first segment restricted to several small spots, intermediate segments pollinose to apices or nearly so, with three large polished black triangular spots, sometimes merging apically in the third, fourth without spots, pollinose on the basal half; first two segments each with a pair of strong median marginal bristles, third and fourth each with marginal rows of about twelve. Wings hyaline; section of fourth vein beyond bend, arcuate, but lacking an angular bend; distance from bend to hind cross-vein one-third to one-fifth the preceding section; last section of fifth vein almost half length of preceding section. Legs black; second joint of fore tarsus (pl. 3, fig. 15) bearing on the ventral side a conspicuous tuft of long bristly hairs in form of a horizontally flattened brush having its tip upcurved; last three tarsal joints much reduced in size and arched above the brushlike tuft; third segment distinctly thicker than the two apical joints which are small and elongate; hind tibia with about twelve unequal bristles in the outside row, of which one bristle near middle is much the largest.

Female.-Front at narrowest 0.45 of the head width in one specimen measured; vertex and front golden pollinose; third antennal joint two and one-half times length of second. Fore tarsus with the four apical joints flattened but not reduced in size or bearing a long tuft of hair. Otherwise, save for the usual difference in genitalia, like the male.

Length, 7.0 to $8.5 \mathrm{~mm}$.

Type and allotype.-Male. Cat. No. 28159 U.S.N.M. The male type collected, Hood River, Washington, July 5, 1917 (F. R. Cole); the allotype female from Mount Constitution, Washington.

Range.-Washington, Oregon, California, British Columbia.

Host relationships.-Unknown. 
Described from the following: In the collection of the National Museum; one male from Hood River, Oregon, one female from Mount Constitution, Washington, July 17, 1909 (J. M. Aldrich); one male from Pine Lake, southern California (Johnson). In the Canadian National collection; one female, Lillooet, British Columbia, 26-vii1917 (J. D. T.), 3,000 feet; another female and one male from same locality 23-vii-1917 (J. D. Tothill) 1,500 feet; one male and one female, Victoria, British Columbia, 2-vii-1921 (W. Downes); two males labelled Pehticton, 18-vi-1918 (W. B. Anderson). In the collection of the writer one male from Hood River, Oregon.

\section{Genus HILARELLA Rondani}

Hilarella Rondani, Dipt. ital. Prodr., vol. 1, p. 70, 1856; vol. 3, p. 212, 1859. Genotype Miltogramma zetterstedti Rondani, which according to Bezzi and Stein, Palaark Dipt., vol. 3, p. 514, 1907 equals hilarella Zetterstedt.

This genus differs from all but two of the North American genera of Miltogramminae, namely Opsidiopsis and Taxigramma, in having the last section of the fifth vein distinctly more than half the length of the preceding section. It is readily distinguished from Opsidiopsis by the absence of a definite row of bristles on the first vein. From Taxigramma, to which it is morphologically very closely related, it differs in having the appendicular fold of the fourth vein shorter than the discal cell, and the last section of the fifth distinctly less than the length of the preceding section. Other generic characters are as follows: a single frontal row on either side of the vitta, descending below the base of the antennae, suddenly divergent below; proclinate ocellars present; orbital bristles in both sexes; vibrissae inserted less than length of second antennal joint above front edge of oral margin; facial ridges with bristly hairs on less than the lowest fourth; antennae extending to less than length of second antennal joint from the vibrissae; penultimate joint of arista scarcely longer than broad; in profile, the head length at the vibrissae distinctly less than at base of antennae; no pale hairs on bucca or back of head about the oral cavity; proboscis stout and much shorter than the head height; thorax with two sternopleural bristles; abdomen densely pollinose, with transverse rows of sharply defined black spots; wings with apical cell closed and ending far before the extreme tip of the wing; mesotibia with a single bristle on outer front side near the middle.

In this genus there are several European species, one of which also occurs in the North American fauna. 
OTHER SPECIES OF HILARELla MENTIONED BY COQUILletT 36 AND ALDRICH ${ }^{37}$

decens Townsend, assigned to genus Eumacronychia.

fulvicornis Coquillett, assigned to genus Phrosinella. polita Townsend, assigned to genus Gymnoprosopa. siphonina Zetterstedt equals Hilarella hilarelia. aristalis Coquillett, assigned to genus Oestrohilarella. rufiventris Coquillett, assigned to genus Senotainia.

HILARELLA HILARELLA (Zetterstedt)

Miltogramma hilarella Zetrerstedt, Dipt. Scand., vol. 3, p. 1212, 1844.

Miltogramma siphonina Zetterstedt, Dipt. Scand., vol. 3, p. 1213, 1844; vol. 8 , p. 3255 , 1849; vol. 12 , p. 4704, 1850; vol. 13, p. 6154, 1859.

Hilarella zetterstedti Rondani, Dipt. ital. Prodr., vol. 1, p. 70, 1856; vol. 3, p. 213, 1859. Equals hilarella, according to Bezzi and Stein, Kat. Pal. Dipt.-Schiner, Faun. Austr., vol. 1, p. 504, 1862.-Brauer and Bergenstamm, Denkschr. Akad. Wien, vol. 51, pl. 6, fig. 133, 1889. Misellia siphonina Robineau-Desvoidy, Dipt. Envr. Paris, vol. 2, p. 148, 1863.

Misellia brunnicosa Robineau-Desvordy, Dipt. Envr. Paris, vol. 2, p. 148, 1863.

Heteropterina hilarella PAndelle, Rev. entom., vol. 14, p. 312, 1895.

Hilarella siphonina Coquillett, U. S. Bur. Ent., Tech. Ser., No. 7, p. 129, 1897.--Sмiтh, Insects of New Jersey, p. 782, 1909.

Bezzi and Stein ${ }^{38}$ place brunnicosa and siphonina in the synonymy of dira Robineau-Desvoidy. But dira equals Miltogramma conica Fallén, according to Robineau-Desvoidy's own statement, and conica belongs to Sphecapata equals Senotainia, an entirely distinct genus. I find from a study of Zetterstedt's original descriptions that siphonina agrees closely with hilarella, differing from it principally in having the segments of the abdomen marked with minute brown spots, whereas hilarella has transverse rows of three larger spots. An examination of the available American and European material indicates that most of the specimens have the transverse rows of three large spots, but in some specimens this character is variable. On one female in my collection, from Lafayette, Indiana, the spots on the abdomen are small, and the usual median one has been broken into two smaller ones, about the bases of the two median marginal bristles. In another specimen from Europe, labeled Hilarella hilarella by Professor Bezzi, the side spots are large, but as with the Indiana specimen, there are two small apical spots about the bases of the two median marginal bristles. These characters, unsupported by others, can scarcely be considered as of specific importance, hence it is my opinion that siphonina equals hilarella.

The principal characters of the species are as follows: The anterior part of the frontal vitta, the first two joints of the antennae and

\footnotetext{
${ }^{36}$ U. S. Bur. Ent. Tech. Ser., no. 7, p. 128, 1897.

${ }^{37}$ Cat. of N. A. Dipt., p. 476, 1905.

${ }^{38}$ Kat. Pal. Dipt., vol. 3, pp. 513-514.
} 
usually the third, the venter and sides of the abdomen, and usually the trochanters, femora and tibiae, yellow; the lowest bristle in the frontal row much smaller than the preceding one; three proclinate and one reclinate orbital bristles; parafrontals bare of bristly hairs; parafacials black setulose; arista conspicuously plumose at middle, thickened on the basal two-fifths; thorax lacking black vittae, with three postsutural dorsocentral bristles; scutellum with three pairs of strong and nearly equal marginal bristles; each of last three abdominal segments with a transverse row of three, or sometimes four round black spots on the dorsum, and two other elongate spots on lateral angles; first segment without macrochaetae, intermediate segments with median marginal pairs; fourth with the usual marginal row; the genital segments of the male genitalia (pl. 1, fig. 3) in repose, concealed, but leaving the minute, sharply pointed, divergent, and slightly bowed prongs of the inner forceps exposed; wings hyaline, with a strong costal spine; third vein with one to three bristles near its base.

This discussion is based on the study of the following material: In the collection of the United States National Museum and Doctor Aldrich's collection, one specimen from Los Angeles County, California, two from Colorado, and one from Clementon, New Jersey (Coquillett); one from Koebler, New Mexico (W. R. Walton); one from Holly Springs, Mississippi (F. W. Mally); two from Tinajas (?) Arizona (W. J. McGee); two from White Springs, Florida (C. H. T. Townsend); one from Hot Springs, Arkansas (H. S. Barber); two from Lafayette, Indiana; seven labeled "Parker Note 45," and one labeled "Parker Note 55," from District of Columbia. In the collection of Prof. J. S. Hine, one from Germit, Pennsylvania (Harbeck), and another from Clementon, New Jersey. In the collection of Nathan Banks there are specimens collected from honeydew of tulip tree, at Falls Church, Virginia, and in that of the Museum of Comparative Zoölogy at Cambridge, Massachusetts, one specimen collected by H. E. Smith in Massachusetts. In Dr. C. W. Johnson's collection there is one specimen from Indiana. In my own collection occurs one specimen from Tupelo, one from Holly Springs, and one from McHenry, Mississippi (H. W. Allen); one from Lafayette, Indiana (E. W. Stafford); one from Agricultural and Mechanical College, Mississippi (M. R. Smith).

Range.-Massachusetts, New Jersey, Pennsylvania, District of Columbia, Virginia, Indiana, Mississippi, Arkansas, Colorado, New Mexico, Arizona, California.

The puparium has been carefully described and figured by Greene ${ }^{39}$ who distinguishes the following characters. Walls smooth. Bottom edge nearly straight; depression in the dorsum at about the apical fifth. A deep pit at anal end, touching the horizontal bisecting plane,

${ }^{30}$ Proc. U. S. Nat. Mus., vol. 60, p. 12, 1921. 
but largely below it. Posterior spiracles located on the upper surface of the pit, and provided with three small, straight, nearly vertical slits. Anal opening on the ventral surface of the puparium.

This species is not known to be attracted to flowers, but has been observed feeding on foliage and dry leaves smeared with honeydew.

Prof. J. B. Parker has secured some interesting notes on the biology of Hilarella hilarella at Washington, D. C. In one instance, on July 11, 1914 (Parker Note 45), a female of Sphex extrematata, var. pictipennis Walsh, was observed entering her burrow with a caterpillar. As she emerged a small fly alighted at the edge of the vertical opening of the burrow and deposited several maggots on the edge. These wriggled over the edge and dropped to the bottom. Three maggots were counted but there may have been more. A fly, apparently the one which deposited the maggots, was captured. The wasp, after closing the entrance, was also captured. On the following day the nest was dug up. A single caterpillar was found about an inch below the surface. No egg of the wasp was present, but four dipterous maggots were on the outside, and subsequent results indicate that four more must have been on the inside. On July 15 the maggots had completely devoured the caterpillar and had buried themselves in the sand of the breeding cell. On July 16 eight puparia were present, from which four flies issued on August 1 and three others on August 2. In another instance (Parker Note 55) a fly was captured which had persistently attempted to place its maggots on a caterpillar that Psammophila violaceipennis Lepeletier had captured and was dragging to her nest.

M. R. Smith has also reared the fly from the nest of Sphex extrematata, var. pictipennis, at Agricultural and Mechanical College, Mississippi. In the instance under his observation, he feels quite certain that the adult fly deposited active maggots on the paralyzed caterpillar when it was laid aside by the wasp preparatory to opening its nest. Since the caterpillar from which the flies were reared was dug up immediately after the nest had been closed by the wasp, and since with this species of wasp only one caterpillar is placed in a nest and the burrow is carefully closed both before and after depositing the prey, and as in this case the fly did not enter the burrow, apparently no other opportunity to establish its progeny was offered the fly than that furnished by the wasp in dropping its prey to open the nest. One nest containing a caterpillar of Chloridea obsoleta was dug up, and the following day three dipterous maggots were observed working upon it. All of them pupated, and from the puparia one adult of Hilarella hilarella issued. 


\section{Genus TAXigRamMa Perris}

Taxigramma Perris, Annal. Soc. Linn. Lyon for 1850, p. 209, 1852. Genotype, Miltogramma heteroneura Meigen as pipiens, new species.-Townsend, Proc. Ent. Soc. Wash., vol. 14, p. 52, 1912.

Heteropterina Macquart, Annal. Soc. Ent. France for 1854, p. 426, 1854. Genotype, Miltogramma heteroneura Meigen.-Schiner, Faun. Austr., vol. 1, p. 502, 1862.-Brauer and Berganstamm, Zweifl. d. Kaiserl. Mus., vol. 56, p. 113, 1889.-Adams, in Williston's Manual of N. A. Dipt., p. 371, fig. 150, no. 62,1908 .

Elpigia Robineau-Desvoidy, Dipt. Envr. Paris, vol. 2, p. 149, 1863. The genotype, pellucida Robineau-Desvoidy, according to Bezzi and Stein, Kat. Pal. Dipt., equals heteroneura Meigen, which is also the type of Taxigramma.

Nasonimyia Townsend, Proc. U. S. Nat. Mus., vol. 49, p. 619, 1915 . The genotype, Heteropterina nasoni Coquillett compared with European specimens of heteroneura with which it was found to be conspecific.

In 1852 Perris described as a new species Taxigramma pipiens. ${ }^{40}$ The single description is for both genus and species. The distinctive characters of size, wing venation, and abdominal markings are definitely described and agree in detail with North American specimens of Miltogramma heteroneura Meigen described in 1830. According to Bezzi and Stein pipiens equals M. heteroneura. ${ }^{41}$ Macquart in $1854,{ }^{42}$ proposed the genus Heteropterina for which heteroneura became the genotype. But since Taxigramma was proposed for pipiens which equals heteroneura, the genotype, some years before Heteropterina, it appears that the former should replace Heteropterina as the name of the genus. Coquillett ${ }^{43}$ pointed out this synonymy in 1910, but for some undetermined reason it has not been generally accepted.

The outstanding character of this genus is the unusual degree to which the wing venation is crowded toward the costa. From the other North American genera of Miltogramminae, it is readilyseparated by the extreme length of the appendicular fold of the fourth vein and the last section of the fifth vein. The fold is distinctly longer than the discal cell, and the last section of the fifth vein longer than the preceding section. Other generic characters are as follows: A single frontal row on either side of the vitta, descending below base of second antennal joint, suddenly divergent below; proclinate ocellar bristles present, and orbitals occur in both sexes; vibrissae inserted near oral margin; facial ridges bristly on less than lowest fourth; lunule conspicuously exposed; antennae extend to less than length of the second joint from vibrissae; penultimate joint of arista scarcely longer than broad; in profile, head length at vibrissae less than at base of antennae; proboscis stout, scarcely as long as head height;

${ }^{40}$ Soc. Linn. Lyon, 1852 , p. 65.

41 Kat. Pal. Dipt., vol. 3, p. $517,1907$.
42 Annal. Soc. Entom. France for 1854, p. 426.

43 Proc. U. S. Nat. Mus., vol. 37, p. 551, 1910. 
abdomen densely pollinose, with transverse rows of small, sharply defined, black spots; apical cell closed at margin of wing.

The genus is represented by several European species, one of which is also widely distributed over North America.

\section{TAXIGRAMMA HETERONEURA (Meigen)}

Miliogramma heteroneura Meigen, Syst. Beschr., vol. 6, p. 367, 1830.Zetterstedt, Dipt. Scand., vol. 3, p. 1214, 1844.

Taxigramma pipiens Perris, Annal. Soc. Linn. Lyons, for 1850, p. 209, 1852 .

Heteropterina heteroneura MaçUart, Annal. Soc. Ent. France, vol. 7, p. 427, 1854.-Schiner, Faun. Austr., vol. 1, p. 503, 1862.-PAndelle, Rev. Ent., vol. 14, p. 313, 1895.-Villeneuve, Bull. Soc. Ent. France, for 1900 , p. 381 .

Elpigia pellucida Robinead-Desvordy, Dipt. Envr. Paris, vol. 2, p. 150, 1863.

Elpigia punctala Robinead-Desvoidy, Dipt. Envr. Paris, vol. 2, p. 150, 1863.

Elpigia minuta Robineau-Desvordy, Dipt. Envr. Paris, vol. 2, p. 151, 1863.

Heteropterina nasoni Coqulllett, Ent. News, vol. 6, p. 207, 1895; U. S. Bur. Ent., Tech. Ser., No. 7, p. 76, 1897.-Walton, Proc. U. S. Nat. Mus., vol. 48, p. 181, 1914.-Reinhard, Ent. News, vol. 30, p. 281, 1919. Cole and Lovetr, Proc. Cal. Acad. Sci., vol. 11, p. 301, 1921.

A single female specimen from Hungary, determined as heteroneura by Prof. Karl Sajo, I have compared with North American specimens of nasoni Coquillett, and another European specimen determined as heteroneura by Kertesz, with the type of nasoni, and it is my conviction that the European and North American forms are conspecific. In the synonomy of the three species of Elpigia proposed by RobineauDesvoidy, I have followed Bezzi and Stein. ${ }^{44}$ The type of (Heteropterina nasoni) Coquillett is located in the United States National Museum, the location of the other types not known to the writer.

The frontal vitta, antennae, palpi, abdomen, femora, and tibia largely yellowish. Front at narrowest measuring 0.34, 0.34, 0.34, $0.34,0.36$, averaging 0.34 of the head width in five males; $0.35,0.36$, $0.38,0.40,0.40$, averaging 0.38 in five females; frontal vitta at level of lowest orbitals one-half to one-third as wide as either parafrontal; two proclinate orbital bristles present; the lowest bristle of the frontal row much weaker than the others; third antennal joint one and onehalf to two times as long as the second; arista thickened on basal third; parafacials bare or with microscopic black hairs. Thorax densely pollinose, without black vittae; scutellum bears three pairs of marginal bristles of which the intermediate pair is much the strongest. The last three abdominal segments each with a transverse row of three small round black spots on the dorsum, and two other elongate spots on the lateral angles; first segment usually,

\footnotetext{
4t Kat. Pal. Dipt., vol. 3, p. 517, 1907.
} 
the intermediate always, with a pair of strong median marginal macrochaetae, fourth with a marginal row. Wing with one or two strong costal spines; third vein bristly at least half way to small cross vein.

Length 3.5 to $6.0 \mathrm{~mm}$.

These notes are based on the study of the following material: A long series of both sexes in the National Museum, including one European specimen determined by Kertesz; one male from Algonquin, Illinois, type for (nasoni); one from Lafayette, Indiana, two from Mandan, North Dakota, two from Bottineau, North Dakota, one from Boise and another from Lewiston, Idaho (J. M. Aldrich); three from Beach, North Dakota, labeled "taken from sunflower, Webster No. 23302" (C. N. Ainslie); one from South Dakota; three from Colorado (Coquillett); one from Wild Horse Canyon, Animas Mountains, New Mexico, 5,000 feet; one from Soroco, New Mexico (Williston); two from Koehler, New Mexico, Webster No. 7707 (W. R. Walton); one from Ormsby County, Nevada (Baker); two from Kaslo, British Columbia (A. N. Caudell); Waubamic, Parry Sound, Ontario. In the Museum of Comparative Zoölogy at Cambridge, Massachusetts; one female from Hungary, determined by Prof. Karl Sajo, and specimens from Milwaukee, Wisconsin (G. Graenicher), and Massachusetts (H. E. Smith).

Range.-Massachusetts, Indiana, Illinois, Wisconsin, North Dakota, South Dakota, Colorado, New Mexico, Texas, California, Nevada, Utah, Idaho, Oregon, British Columbia, and Ontario. It is also, according to Bezzi and Stein, widely distributed over Europe.

Host relationships.-Reared from grasshopper by C. N. Ainslie at Payson, Utah. ${ }^{45}$ This is an unusual record for a Miltogramminid. It is questionable whether this fly will prove to be normally parasitic on the active stages of grasshoppers or other herbaceous insects.

Reinhard ${ }^{46}$ has noted the species as being persistently present in Texas during May, June, and July. Several specimens were taken in the insectary and others from sweeping grass and foliage near the ground.

\section{Genus EUMACRONYCHIA Townsend}

Eumacronychia Townsend, Trans. Amer. Ent. Soc., vol. 19, p. 98, 1892, genotype decens in the University of Kansas Museum; Trans. Amer. Ent. Soc., vol. 22, p. 74, 1895; Smithson. Misc. Coll., vol. 51, p. 64, 1908.Coquillett, U. S. Bur. Ent., Tech. Ser., No. 7, p. 128, 1897; Proc. U. S. Nat. Mus., vol. 37, p. 541, 1910 (equals Hilarella).

This genus, erected by Townsend in 1892, has long been considered synonymous with Hilarella and has never been generally accepted. After a careful study of available material, including genotype speci- 
mens of Hilarella, and decens, the type of Eumacronychia, I am convinced that the latter is generically distinct. The species of Eumacronychia as a whole possess almost the same combination of characters as those of Gymnoprosopa, and certain species such as elita and rohweri possess striking resemblances to both genera, but the male genitalia in Eumacronychia are uniformly large and highly specialized, somewhat resembling those of typical Sarcophaginae, while the male genitalia of Gymnoprosopa are small and relatively unspecialized as in Metopia and related genera. In Eumacronychia, the female genital segments extrude conspicuously, the apical scutellar bristles are absent or if present are much smaller than either pair of lateral marginals, the front is usually distinctly narrower near base of the antennae than towards the vertex, and the male usually possesses conspicuously long broad pulvilli, and a tendency toward villosity on the legs, all characters distinguishing it from Gymnoprosopa. Other characters of the genus are as follows:

Inner orbits not sinuous or pinched in at the level of vibrissae; frontal vitta light red or yellow, at least as wide as the parafrontal, diverging moderately toward the vertex; lunule scarcely visible; a single frontal row of bristles terminating at base of antennae, not suddenly divergent below; proclinate ocellar bristles present; orbitals in both sexes; antennae distinctly more than half as long as the face; penultimate joint of the arista short; vibrissae not more than the length of second antennal joint above front edge of oral margin; in profile, head length at vibrissae sometimes subequal, usually much less than at base of antennae; lower part of bucca with sparse black bristly hairs; no pale hairs about the oral cavity; proboscis moderately stout, shorter than the head height, with fleshy labella and normal palpi. Thorax with three strong postsutural dorsocentral bristles and two sternopleurals. Pollen on the intermediate segments of the abdomen arranged in basal bands which are not scalloped or indented on the apical margin; abdomen never marked with large black spots. Wing with apical cell open; only the third vein bristly; last section of fifth vein less than half the length of the preceding section. Joints of the fore tarsus not ornamented, conspicuously reduced in size, flattened, or otherwise modified from the normal in either sex; pulvilli of male variable in length.

None of the species of this genus are known at present from outside the continental North American area. I have seen very few specimens from north of the latitude of New Jersey. The genus is composed of several species of attenuated or possibly discontinuous distribution. Not one of the species is definitely known to have a transcontinental range except sternalis identified from Galveston, Texas, and Granada, Nicaragua. The Southwest appears to be the center of distribution of the group. Nothing is known concerning 
the host relationships and scarcely more concerning the habits of the species in this genus.

KEY TO NORTH AMERICAN SPECIES OF EUMACRONYCHIA

1. Fourth abdominal segment wholly black _.......... 5 .

Fourth abdominal segment red, at least on its apex

2. Parafacials at most with sparse black bristly hairs on the lower half of face; third antennal joint bright red or yellow; claws of inner forceps of male

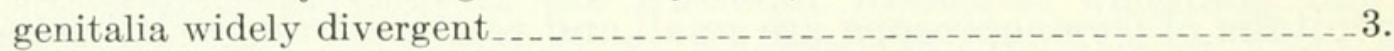

Parafacials on upper half, thickly beset with black bristly hairs; third joint of antennae black; claws of inner forceps of male genitalia not divergent.

nigricornis, new species.

3. Arista thickened on basal three-fifths; inner orbits divergent from base of antennae to vertex; fourth sternite of male ordinary . . . . . . . . . 4 .

Arista thickened on basal two-fifths; inner frontal orbits parallel; in male the fourth sternite is conspicuously exposed and covered with short erect villosity, and the prongs of inner forceps are not bowed in the middle, pulvilli longer than the last two tarsal joints; in female, first genital segment appearing like a fifth abdominal segment, not arched like an inverted $\mathbf{V}$, but broadly rounded above.................. sternalis, new species.

4. Bucca in profile equals one-half eye height; facial depression scarcely wider than either parafacial; in male, pulvilli longer than the last two tarsal joints, prongs of inner forceps strongly bowed in middle when viewed from behind, apical flexor surface of middle tibia with long, erect villosity; in female, first genital segment resembles a fifth abdominal segment and is arched

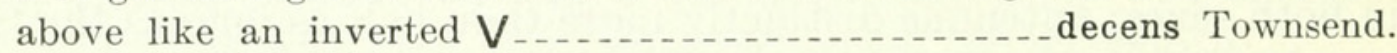

Bucca in profile equals one-fifth eye height; facial depression twice width of either parafacial; in male, pulvilli shorter than last two tarsal joints, prongs of inner forceps when viewed from behind are not bowed in middle; middle tibia without erect villosity_._._.

5. Parafacials distinctly hairy; arista thickened on basal two-fifths; palpi and third antennal joint black $-6$.

Parafacials bare; arista thickened on basal three-fifths; palpi yellow.

elita Townsend.

6. Intermediate abdominal segments with sharply defined pollinose bands on basal two-thirds; buccal width less than one-third eye height.

rohweri, new species.

Intermediate abdominal segments densely pollinose to apices; buccal width exceeds one-third the eye height._._._._._elongata, new species.

\section{EUMACRONYCHIA DECENS Townsend}

Eumacronychia decens Townsend, Trans. Amer. Ent. Soc., vol. 19, p. 99, 1892 ; vol. 22, p. 74, 1895.

Hilarella decens Coquillett, U. S. Bur. Ent., Tech. Ser., No. 7, p. 128, 1897.- - Ммгтн, Ins. of New Jersey, p. 782, 1909.

Male.-Front at narrowest point, which is just above the base of the antennae, 0.35 of head width (measurements of three as follows: $0.33,0.34,0.37)$; frontal vitta at level of lowest orbitals one and onehalf times width of either parafrontal; frontal row with about ten bristles; one reclinate and three proclinate orbital bristles; parafrontals with a few short bristly hairs near the vertex; facial depression scarcely wider than either side of face; vibrissae inserted nearly 
length of second antennal joint above front edge of oral margin, and approximated to distance nearly twice its length; facial ridges with but two or three small hairs above the vibrissae; antennae yellow, third joint four times length of second; arista thickened on basal three-fifths; in profile, bucca wider than parafacials and equals one-half eye height; front projects nearly one-half eye height; head length at vibrissae slightly less than at base of antennae; parafacials with microscopic white pile; palpi yellow. Thorax densely gray pollinose, with one to three narrow median and two broader lateral vittae; apical scutellar bristles much smaller than the other two marginal pairs; small preapicals present. Abdomen black excepting the fourth segment which is broadly yellow; last three segments with dense white pollinose bands on basal half; second segment with a median marginal pair of bristles; third and fourth segments with marginal rows of from six to ten; venter densely villous, fourth segment not conspicuous. Genital segments yellow, first segment bare, second with very short bristly hairs; inner forceps curved slightly forward, tapering gradually to sharp, black tips; when viewed from the rear, the prongs are separated and strongly bowed at the middle Wing hyaline, bearing a small costal spine; third vein bristly about half way to small cross-vein; hind cross-vein parallel to section of fourth vein beyond the bend. Legs black, with conspicuous claws and pulvilli which are longer than the last two tarsal joints on all the feet; middle tibia with one bristle on outer front side near the middle, on apical half of flexor side with distinct, villous, suberect hair, in best view, as long as width of tibia; hind femur moderately villous; hind tibia with three uneven bristles on outer surface before the middle; on flexor surface with rather long appressed hair.

Female.-Several specimens which most closely resemble the male have the following characters. Front at narrowest point 0.40 of the head width (measurements of four as follows: $0.40,0.40,0.40,0.41$ ); third antennal joint three to four times as long as the second; in profile, bucca scarcely one-third eye height. Second abdominal segment lacking macrochaetae, third segment with very weak marginals outside the median pair. First genital segment large, fully exposed, simulating a fifth abdominal segment, with a sharply pointed, inverted $\mathbf{V}$-shaped arch above, drawn together at the sides. Femora and tibiae without villosity. Otherwise save for the usual differences of genitalia, like the male.

Length, 5.5 to $8.5 \mathrm{~mm}$.

Host relationships.-Unknown.

This species was originally described from four males and nine females, all apparently cotypes. The type series which was deposited in the University of Kansas Museum has dwindled to three, of which one fortunately is a male. This material was loaned to the National 
Museum and carefully examined and compared with other material by Dr. J. M. Aldrich, upon whose examination this redescription is based. Other material examined is as follows: One male from Los Angeles County, California, August; one male, Socorro, New Mexico, 1916 (Williston); one female from Hot Springs, Arkansas (H. S. Barber); one female from Wild Horse Canyon, Animas Mountains, New Mexico, 5,000 feet; one female, Yuma, Arizona, June 25, 1917 (J. M. Aldrich); one female from Fort Grant, Arizona (H. G. Hubbard); two females from Los Angeles County, California, July; all in the collection of the National Museum. One female in the collection of Prof. J. S. Hine, collected at College Station, Texas. The male in the University of Kansas Museum, labeled "Las Cruces, N. M. 7-7," designated as type.

There are now known to be several very closely related species resembling decens in the southwestern part of the United States. While the males possess outstanding characters, the females I have examined have proved more difficult and have been somewhat uncertainly placed. Females agreeing with the males of decens in the appearance of the arista, the degree of approximation of the vibrissae, and in having the front narrowest just above the base of the antennae have been assigned to this species.

EUMACRONYCHIA MONTANA, new species

Male very closely resembles $E$. decens from which it differs in the following characters: Front at narrowest, 0.29 of the head width in one specimen measured; trontal vitta densely pollinose over the yellow; frontal row of about seven weak bristles; one reclinate and two proclinate orbital bristles present; facial depression twice the width of paratacial; length of third joint of antenna three times the second; vibrissae inserted at one-half the length of second antennal joint above front edge of oral margin; in profile, bucca subequal to parafacial, equal to one-fifth eye height; parafacial bare. Prongs of inner forceps of genitalia divergent, but not bowed when viewed trom the rear; outer forceps tapering to points more slender than those of inver pair, broadly curved towards tips of latter. Wings without costal spine. Pulvilli as long as last tarsal joint; tibia without long villous hairs. Female not known.

Type--Male. Cat. No. 28160, U.S.N.M. Mesilla Park. New Mexico.

Described from one male from Mesilla Park, New Mexico (C. N. Ainslie), in the collection of the National Museum; and one male from Mount Superstition, near Higley, Arizona, July 26, 1917, on Agave palmeri (E. G. Holt), loaned by J. R. Malloch. 
EUMACRONYCHIA STERNALIS, new species

Very closely resembles $E$. decens, from which it differs in the following characters:

Male.-Front 0.385 of the head width (measurements of two 0.38 and 0.39 , respectively); inner orbits parallel from vertex to base of antennae; frontal vitta at level of lowest orbitals twice as wide as either parafrontal; one reclinate and two proclinate orbital bristles; vibrissae strongly approximated, to a distance scarcely exceeding length of second antennal joint; third joint of antenna three times length of second; arista thickened on basal two-fifths. Abdomen black, at least the apex of fourth segment reddish; fourth sternite conspicuously exposed and covered with short dense black villous hairs. Inner forceps of the genitalia, when viewed from behind, not bowed in the middle; outer forceps about as stout as the inner pair, grooved behind, broadly curved toward tip of inner forceps but pointed toward penis at the extreme tip. Villosity on apical flexor surface of middle tibia as long as half the width of tibia; hind tibia with only ordinary black appressed hair.

Female.-I have examined several specimens which resemble the male in having the inner orbits nearly parallel and the vibrissae closely approximated and which are evidently conspecific with it. They also very closely resemble the female described for E. decens, from which they may be distinguished by the following characters: Front slightly wider, averaging 0.415 in four specimens measuring $0.41,0.41,0.42$, and 0.42 , respectively. The first genital segment simulates a fifth abdominal segment, with marginal macrochaetae, but is not arched in an inverted $\mathbf{V}$-shape manner.

Length, 5.0 to $9.0 \mathrm{~mm}$.

Type--Male. Cat. No. U.S.N.M. 28161, Galveston, Texas.

Host relationships.-Unknown.

Described from one male from Galveston, Texas, VIII-28-1914, Bishopp No. 3516 (F. C. Bishopp); one male from Granada, Nicaragua (Baker); one female from Las Cruces, New Mexico, July 7 , marked "type" and evidently one of Townsend's cotypes of E. decens incorrectly identified; one female from San Jose de Cabo, southern California (Townsend); one female from Los Angeles County, California, September; all in the collection of the National Museum. One female from Brewster County, Texas, June 13-17, 1908 (Mitchell and Cushman) occurs in the Museum of Comparative Zoology of Cambridge, Massachusetts; and one female from San Jose, Guatemala, February 5, 1905, was seen in the collection of Prof. J. S. Hine. 
EUMACRONYCHIA NIGRICORNIS, new species

Male.-Front at narrowest 0.24 of the head width (in the single specimen examined the front appears somewhat crushed in and therefore may be narrower than normal); face and front yellow, overlaid with silvery pollen; inner orbits most nearly approximated at base of antennae, diverging moderately toward vertex; frontal vitta paleyellow, with sides slightly convergent to before middle, thence moderately divergent to vertex, at level of lowest orbital one and onehalf times width of either parafrontal; nine bristles in frontal row which extends downward as far as base of second antennal joint; one reclinate and two proclinate orbital bristles present; parafrontals with long, erect, black, bristly hairs continuous down over parafacials to lower end of eye; vibrissae separated by a distance nearly twice the length, and inserted one half the length, of the second antennal joint above front edge of oral margin; facial ridges with one or two small bristly hairs above vibrissae; antennae with second joint red, third joint black or at most with dense black tomentum over red, three times length of second; arista thickened on basal three-fifths; in profile, buccal width greatly exceeds that of the parafacials and equals one-third the eye height, head length at vibrissae much less than at base of antennae, front projects about one-half the horizontal diameter of the eye; palpi pale yellow, slightly clavate. Thorax gray pollinose, marked with three broad black vittae which are continuous to the scutellum; three postsutural dorsocentral bristles present; scutellum with two pairs of strong marginal bristles, a pair of minute decussate apicals, and another pair of small preapicals. Abdomen black, save the apex of the fourth segment, which is red; basal two-thirds of last three segments gray pollinose with bronzed reflections; apices of the intermediate segments and a broad median dorsal vitta, polished black; first segment with a single lateral bristle; second with one lateral and one strong median marginal pair; third and fourth each with an uninterrupted marginal row of eight to ten bristles; venter clothed with long erect villosity, the length of which exceeds the diameter of the hind femur. Genital segments large, pale yellow, lacking macrochaetae; first segment bare, second clothed with minute black, bristly hairs; inner forceps with black tips, in profile straight nearly to apex, thence curved abruptly forward, claws not divergent; outer forceps less massive and slightly shorter than the inner pair, tapering rapidly to just before the black tips, thence expanding in a small angular head, apposed to the tips of the inner forceps; anterior claspers large, black, sickle-shaped; penis supported by usual heavily chitinized rod terminating in a ring, from the center of which arises a posteriorly directed, bottle-shaped, membranous hood. Wings hyaline; fourth vein with a right-angular bend; section beyond the bend nearly parallel to the hind cross vein; costal 
spine minute; third vein with a row of small bristles extending more than half-way to the small cross vein. Legs black; pulvilli of the forefeet as long as, of the other feet, slightly shorter than, the last two tarsal joints; inner proximal surface of femora with fine erect villosity, in length nearly equal to greatest diameter of femur; middle tribia with one bristle on outer front side near the middle, and with dense erect villosity on inner distal surface equaling diameter of tibia; hind tibia on outside with row of four or five unequal bristles, of which the distal one is much the largest and is inserted just beyond the middle.

Female.-Front at narrowest 0.39 of head width in the single specimen measured; frontal vitta with its sides parallel. Abdomen without macrochaetae on the first segment, a minute pair of median marginals on the second, one lateral and one pair of strong median marginals on the third; venter of abdomen and legs without long erect villosity. The first genital segment simulating a fifth abdominal segment, broadly rounded above, and enclosing two elongate valves which meet in a long slit on the longitudinal-vertical bisecting plane. Pulvilli one-half length of last tarsal joint.

Length, 5.5 to $8.0 \mathrm{~mm}$.

Type--Male. Sugar Grove, Ohio, May 19 (J. S. Hine).

Allotype.-Female. Sugar Grove, Ohio, May 19 (J. S. Hine).

Described from two specimens in the collection of Prot. Hine.

Host relationships.-Unknown.

\section{EUMACRONYCHIA ELITA Townsend}

Eumacronychia elita Townsend, Trans. Amer. Ent. Soc., vol. 19, p. 100, 1892 ; vol. 22 , p. 74, 1895.

Hilarella elita Coquillett, U. S. Bur. Ent., Tech. Ser., No. 7, p. 129, 1897. Senotainia fasciata Coquillett, U. S. Bur. Ent. Tech. Ser., No. 7, p. 81, 1897.

Male.--Front at narrowest 0.34 of the head width (measurements of two being 0.32 and 0.36 respectively); vitta yellow, when viewed from the front, whitish pollinose, narrower than parafrontal at base of antennae, but gradually widening to three times width of parafrontal at ocellar triangle; parafrontals silvery, destitute of bristly hairs; about six bristles in frontal row; parafacials, facial depression and bucca silvery white; vibrissae inserted slightly more than half length of second antennal joint above front edge of oral margin; antennae extend four-fifths distance to vibrissae, second joint red, third joint yellow with dark reflections or black, the anterior apical margin sharply angulate, length one and one-half to two and one-half times second; arista thickened on basal three-fifths; parafacials bare; in profile, buccal width equals one-third eye height, length of head at vibrissae slightly less than at base of antennae, epistoma not protruding; proboscis almost as long as head; palpi yellow and dis- 
tinctly clavate. Thorax densely gray pollinose, with two obscure vittae; scutellum with two pairs of strong marginal bristles, apical pair lacking. Abdomen black; segments shining on apices; basal halves of last three with broad white pollinose bands sharply defined from the black and not extending over the venter, first abdominal segment with one lateral and one weak median marginal pair of bristles, second with one lateral and one strong median marginal pair, the last two with marginal rows of about eight, the marginal bristles of the third as strong as those of the fourth segment. Genitalia large, black, in repose prominently extruding from tip of abdomen, exposed for distance about two-thirds the length of the fourth abdominal segment; second genital segment distinctly longer than first. Wings hyaline; posterior cross vein parallel with the nearly straight section of the fourth vein beyond the bend; last section of fifth vein equals one-third the preceding section; costa with a small spine; third vein with a row of small bristles reaching more than halt way to small cross vein. Legs black; pulvilli of fore feet nearly one and one-half times length of last tarsa] joint; one small bristle on outer front side of middle tibia near its middle; hind tibia with two unequal bristles on outside surface before the middle.

Female.-Not known.

Length, 3.0 to $5.0 \mathrm{~mm}$.

Host relationship.-Unknown.

Redescribed from the type, which is a male from Las Cruces, New Mexico, August 7, and another male from the same locality, September 17, which is Coquillett's type for Senotainia fasciata, both in the National Museum.

\section{EUMACRONYCHIA ROHWERI, new species}

Male.-Front in the single specimen measured 0.31 of the head width; frontal vitta yellow, with parallel sides on anterior half, moderately divergent posteriorly, at level of lowest orbitals slightly more than twice as wide as the parafrontal; vertex gray pollinose; parafrontals, whole of face and bucca white pollinose; seven to nine bristles in the frontal row; one reclinate and two proclinate orbital bristles; a few black bristly hairs on the parafrontals outside the frontal rows; vibrissae less than one-half length of second antennal joint above front edge of oral margin; facial ridges with but one or two small bristly hairs just above vibrissae; antennae extend four-fifths distance to vibrissae, second joint brown, third joint black with its length two and one-half times the second and the outer apical angle bluntly pointed; arista thickened on basal two-fifths; parafacials sparsely covered with black bristly hairs; in profile, buccal width nearly equals one-third eye height; proboscis distinctly shorter than height of head; palpi clavate, black. Thorax gray pollinose, merging 
with brown on the notum, with three to five obscure black vittae; scutellum with two pairs of strong marginal bristles, apicals lacking, one pair of weak preapicals. Abdomen black, the last three segments each with a sharply defined, white pollinose band on the basal twothirds, prolonged ventrally to the sternum; first two adbominal segments each with two or more weak laterals and a strong median pair of marginal bristles, third and fourth with uninterrupted marginal rows. Genitalia in repose, prominent, extruding from fourth abdominal segment for distance equal to their length; genital segments shining black, first smaller than the second; fifth sternite conspicuous, armed posteriorly with a tuft of stubby spines, laterally with slender bristles. Wings hyaline; fourth vein beyond the bend slightly arcuate and parallel with the hind cross vein; section from bend to hind cross vein about one-half as long as preceding section; last section of fifth vein about one-fourth as long as preceding section; one small costal spine; third vein with row of small bristles extending approximately half way to small cross vein. Legs black; pulvilli of fore feet one and one-fourth times as long as last tarsal joint; middle tibia with one bristle on outer front side beyond the middle; hind tibia on outside with row of four unequal bristles terminating in the strongest, slightly beyond the middle.

Female.-Not known.

Length, $6.5 \mathrm{~mm}$.

Type.-Male, Cat. No. 2811, U.S.N.M.

Host relationships.-Unknown.

Described from a single male, Florissant, Colorado, June 28, 1908, (S. A. Rohwer) in the National Museum labeled "rohweri."

EUMACRONYCHIA ELONGATA, new species

Male.-Front 0.365 of the head width (in two specimens measured 0.36 and 0.37 respectively); front including the vitta, face, and bueca, densely white pollinose, merging with gray pollen at vertex; vitta with parallel sides to middle thence moderately divergent to vertex, at level of lowest orbitals twice width of parafrontal; frontal row of about six weak bristles extending to base of antennae; one reclinate and two proclinate orbital bristles; parafrontals almost destitute of bristly hairs; vibrissae inserted one-half second antennal joint above front edge of oral margin; one or two small bristles above vibrissae on facial ridges; first two antennal joints brown, third black and two and one-haif times length of second; arista thickened on basal two-fifths; parafacials moderately black setulose; in profile, bucca wider than parafacials at their narrowest and nearly one-half eye height, front projects more than half the horizontal diameter of eye; proboscis slightly shorter than head height; palpi black, distinctly flattened and enlarged at the tip, subfoliaceous. Thorax gray pollinose with two 
narrow obscure vittae near median line, and clothed with short suberect hair; scutellum with two pairs of marginals of which the lateral pair is distinctly smaller. Abdomen long and slender, black, densely overlaid with grayish, bronze-tinged pollen to apices of all the segments; first three segments each with a strong median marginal pair of bristles and two to three strong laterals, fourth with the usual uninterrupted marginal row. Male genitalia prominent, in repose, extruding from tip of abdomen for distance equal to length of last abdominal segment; first segment subshining black with subapical row of about four bristles; second segment dull reddish, sparsely pollinose, moderately beset with fine black hairs; inner forceps black, much less massive than outer pair, about three times longer than greatest width, tapering abruptly to beyond middle, thence gradually to weak, slender, slightly curved tips, united to beyond middle, tips separated by linear cleft; outer forceps yellow at base, tapering abruptly to near tips, thence expanded into large, polished black, laterally compressed, lanceolate points, when viewed from rear the forceps display an inwardly directed angle near the base beyond which they are strongly bowed; penis slender, black, strongly chitinized to tip, hood in profile triangular with a minute membranous process at posterior angle and a spiniferous pit between the posterior and apical angles; posterior claspers large and bearng a prominent bristle, anterior clasper vestigial; fitth sternite much enlarged and heavily chitinized, punctate, with a broad $U$-shaped cleft fringed with a row of long hairs terminating at the lateral angle which is produced as a strong black tooth; fourth sternite closing the genital cavity anterioriy and bearing ventrally near the apex, two small combs of short black bristles. Wings hyaline; small costal spine present; third vein bristly about one-half way to small cross vein. Legs black; pulvilli of fore feet as long as last two tarsal joints; middle tibia with usual bristle on outer front side near middle; hind tibia on outside with three unequal bristles of which the most distal, located slightly beyond the middle, is the largest.

Female.-Not known.

Length, $7.0 \mathrm{~mm}$.

Type.-Male, in the Canadian National Collection from Onah, Manitoba, 21-VI-1921 (P. Vroom).

Host relationships.--Unknown.

Described from the type, and one other male specimen, Glenboro, Manitoba, 7-VI-1920 (H. A. Robertson), in the Canadian National Collection. 


\section{Genus GYMNOPROSOPA Townsend}

Gymnoprosopa Townsend, Trans. Amer. Ent. Soc., vol. 19, p. 108, 1892, type, polita; Smithson. Mise. Coll., vol. 51, p. 64, 1908.-Coquillett, U. S. Bur. Ent., Tech. Ser., No. 7, p. 128, 1897; Proc. U. S. Nat. Mus. vol. 37, p. 548, 1910 (Hilarella).

This genus also, has long been considered synonymous with Hilarella. Genotype specimens of Hilarella and Gymnoprosopa posesss rather striking differences in the conformation of the head and in the distribution of pollen on the abdomen, which are linked with certain minor variations, constant among the species of the respective groups, and should certainly be considered distinct genera. From the more nearly related genus Eumacronychia, Gymnoprosopa differs in having the male genitalia minute, not highly specialized, in repose, largely concealed within the tip of the abdomen, while the female genitalia are small and inconspicuous. These characters associated with smallness, the presence of three pairs of marginal scutellar bristles of which the apical pair is at least as strong as the extreme laterals, and the contour of the inner orbits which are not more nearly approximated near base of antennae than at the vertex, readily distinguish Gymnoprosopa from Eumacronychia. Other characters of the genus are as follows:

Inner orbits not pinched in at level of vibrissae; frontal vitta light red or yellow, at least as wide as the parafrontal; lunule scarcely visible; a single frontal row of bristles terminating at base of antennae, not suddenly divergent below; procinate ocellar bristles present; orbitals in both sexes; antennae distinctly more than half as long as the face; penultimate joint of arista short; vibrissae distinctly less than length of second antennal joint above front edge of oral margin; in profile, head length at vibrissae sometimes subequal, usually much less than at base of antennae; lower part of bucca with sparse black bristly hairs; no pale hairs about the oral cavity; proboscis moderately stout, shorter than the head height, with fleshy labella and normal palpi. Thorax with three strong postsutural dorsocentral bristles and two sternopleurals. Pollen on intermediate segments of abdomen arranged in basal bands which are not scalloped or indented on the apical margin; abdomen never marked with large black spots. Wing with the apical cell open; only the third vein bristly, last section of fifth vein less than half the length of preceding section. Joint of fore tarsus not ornamented, conspicuously reduced in size, flattened, or otherwise modified from the normal in either sex; pulvilli of male variable in length.

None of the species of this genus are known to occur outside the continental North American area, and I have as yet seen no specimens from north of the continental United States. The genus is 
composed of several species of attenuated or possibly discontinuous distribution. Not one of the species is definitely known to have a transcontinental range, and specimens from west of the Mississippi River are not frequently seen in collections. Possibly polita has the widest range, being recorded from Ithaca, New York, to the Animas Mountains, New Mexico, and Florida. Very little is known of the ecology of any of the species of this genus. Scattered information indicates that they frequent low foliage and may be attracted to flowers. Nathan Banks writes that the adults of some species are found feeding frequently on honeydew falling from the tulip tree, Liriodendron tulipifera, in Virginia, and W. L. McAtee has collected another species on the flowers of Ceanothus americanus. Nothing is known of the host relationships in this group.

KEY TO NORTH AMERICAN SPECIES OF GYMNOPROSOPA

1. Parafacials with black bristly hairs $-4$.

Parafacials bare, or at most with minute, scarcely visible hairs _........ 2 .

2. Last three segments of abdomen pollinose on basal half, the pollinose bands thickly beset with black bristly hairs; extreme lateral pair of scutellar

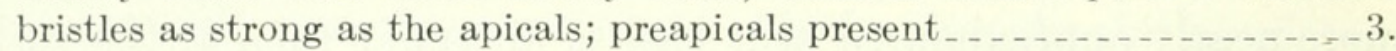

Last three segments of abdomen pollinose on basal third of segment; pollinose bands almost free of bristly hairs; bristles of third abdominal segment as strong as those of fourth; extreme lateral pair of scutellar bristles weaker than apical pair; preapicals lacking; front pulvilli of male less than half as long as last tarsal joint polita Townsend.

3. Frontal vitta pale yellow; third vein with one small bristle near its base; hind cross vein nearly parallel to section of fourth vein beyond the bend; front pulivilli of male one-fourth as long as last tarsal joint; first and second abdominal segments with red on sides_.......... pallida, new species.

Frontal vitta dark yellow to red; third vein with two or three bristles at its base; hind cross vein not parallel to section of fourth vein beyond the bend but perpendicular to preceding section; front pulvilli of male as long as last tarsal joint; first and second abdominal segments without red on the sides

argentifrons Townsend.

4. With three or four proclinate orbital bristles; palpi clavate; third antennal joint conspicuously inflated; second and third abdominal segments pollinose on

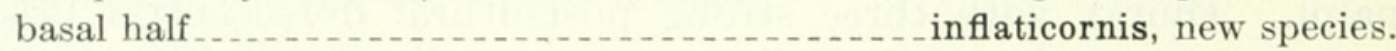

With only two proclinate orbital bristles; palpi filiform; third antennal joint not inflated; second and third abdominal segments pollinose on basal third.

filipalpus, new species.

GYMNOPROSOPA POLITA Townsend

Gymnoprosopa polita Townsend, Trans. Amer. Ent. Soc., vol. 19, p. 109, 1892.

Gymnoprosopa clarifrons Townsend, Trans. Amer. Ent. Soc., vol. 19, p. 109, 1892.

Hilarella polila Coquillett, U.S. Bur. Ent., Tech. Ser., No. 7, p. 128, 1897.Aldrich, Cat. of N. A. Diptera, p. 447, 1905.-Smith, Ins. of New Jersey, p. 782, 1909.-Johnson, Bull. Amer. Mus. Nat. Hist., vol. 32, p. 73, 1913.

After reexamining types of polita, argentifrons, and clarifrons together with a fairly long series of specimens not previously available 
to Coquillett or Aldrich, it becomes evident that polita and clarifrons are synonymous, but that argentifrons, considered synonymous with polita by the above, is clearly a distinct species.

Female.-Front at narrowest 0.43 of head width (measurements of four $0.40,0.42,0.44$, and 0.45 , respectively), noticeably flattened; frontal vitta yellow, with the sides nearly parallel but perceptibly wider at the reclinate orbital than at either end, slightly more than twice width of parafrontal at lowest orbitals; five to six moderately strong bristles in frontal row; one reclinate and two proclinate orbital bristles; the orbitals, ocellars and inner verticals slightly larger than the frontal bristles; parafrontals silvery, bare or rarely with a few sparse hairs; facial ridges with one or two minute bristles just above vibrissae; face silvery; parafacials bare; in profile, buccal width onefourth eye height; vibrissae slightly more than half length second antennal joint above front edge of oral margin; antennae extend four-fifths distance from their base to the vibrissae; second joint red; third joint black and three times as long as the second, straight along front edge with blunt point at outer apical angle; arista thickened on basal half; proboscis slightly less than head height; palpi yellow, distinctly clavate. Thorax gray pollinose over black, with bronze reflections on notum, and with three black vittae of which the median one is narrower than the other two; scutellum with three pairs of marginal bristles of which the extreme lateral pair is distinctly smaller than the apical, but both are much weaker than the intermediate pair. Abdomen shining black, excepting silvery pollinose bases of the last three segments, the pollinose bands less than onethird length of segments, terminating abruptly at the side and not continued ventrally; first segment without bristles, second with one lateral and one median marginal pair, third and fourth with marginal rows of about ten, the bristles of third segment as large or slightly larger than those of the fourth. Wings subhyaline, slightly smoky along the costal margin; last section of fourth vein slightly arcuate and not parallel to the hind cross vein which joins the fourth vein a little less than half the distance from its bend to the small cross vein; last section of fifth vein one-fourth the length of preceding section; two small costal spines; third vein with row of small bristles extending more than half way to small cross vein. Legs black; pulvilli less than half length of last tarsal joint; middle tibia with single bristle on outer front side near middle; hind tibia with row of two to four unequal bristles on outside extending to slightly below the middle.

Male.-Front at narrowest 0.39 of head width (measurements of three $0.36,0.39,0.41$, respectively); frontal vitta diverging slightly towards vertex, more than three times width of parafrontal at lowest orbitals; third joint of antennae three and one-half times as long a second. A tuft of conspicuous hairs located on ventral side of 
fourth abdominal segment. Genitalia in repose concealed within fourth abdominal segment so that apex is barely visible in lateral view; claws of inner forceps rounded and widely divergent from near base, in profile view, bent backward at middle and slightly forward at tip; outer forceps much stouter than inner pair, tapering gradually to spoonlike tips; penis with a black, heavily chitinized, S-shaped process on anterior part of hood. Pulvilli not more than half as long as last tarsal joint. Otherwise resembling the female.

Length, $4.5 \mathrm{~mm}$.

Type.-In the University of Kansas Museum.

Range.-New York, New Jersey, Virginia, Ohio, Illinois, Mississippi, Florida, Kansas, New Mexico.

Host relationships.-Unknown.

Redescribed from the type, a female from southern Florida (Robertson); a male from the same locality (Robertson), and several other specimens in the University of Kansas Museum, the National Museum, the Museum of Comparative Zoology of Cambridge, Massachusetts, and the collections of Prof. J. S. Hine and the writer, from the following localities: one male, Baldwin, Kansas; one female, southern Illinois (Robertson); one female, Wild Horse Canyon, Animas Mountains, New Mexico, 5,000 feet; one female, Rosslyn, Virginia, May 1, 1913 (R. C. Shannon); one female, Woodbury, New Jersey; one female and two males from Falls Church, Virginia, the males from the honeydew of tulip-tree; one female, Ithica, New York, August 11, 1905 (H. E. Smith); one female, West Point, Mississippi, May 15, 1921 (H. W. Allen); one male, Agricultural and Mechanical College, Mississippi, April 2, 1921 (H. W. Allen); one male, Columbus, Ohio.

Townsend's type for $G$. clarifrons which is a male from southern Illinois, corresponds in all distinguishable characters with the type female of polita which is from southern Florida.

\section{GYMNOPROSOPA ARGENTIFRONS Townsend}

Gymnoprospa argentifrons Townsend, Trans. Amer. Ent. Soc., vol. 19, p. 109, 1892.-Coquillett, U. S. Bur. Ent., Tech. Ser., No. 7, p. 129, 1897, equals Hilarella polita.-Aldrich, Cat. N. A. Dipt., p. 447, 1905, equals Hilarella polita.

Male.-Front at narrowest 0.34 of head width (measurements of four $0.32,0.33,0.33$, and 0.37 , respectively); frontal vitta divergent from base of antennae, at most only sighsly wider at middle than at vertex, red, sometimes overlaid with silvery pollen, two to four times as wide as parafrontal at lowest orbitals; five to seven bristles in frontal row; one reclinate and two proclinate orbital bristles; no hairs on front outside of frontal rows; face silvery; antennae black, extending seven-eighths distance from base to vibrissae; third joint 
with its front edge concave and its length five times that of second; arista thickened on basal three-fifths; facial ridges bare; parafacials bare or with almost imperceptible hairs; vibrissae inserted at less than half the length of second antennal joint above front edge of oral margin; in profile, head length at vibrissae distinctly less than at base of antennae, buccal width equaling one-fourth eye height; proboscis distinctly shorter than head height; palpi yellow and moderately calvate at tip. Thorax black, overlaid with gray pollen, tinged with bronze on notum; two widely separated broad black vittae, and occasionally a narrower indistinct median one; scutellum with three pairs of marginal bristles, the nearly equal apical and lateral pairs both smaller than the intermediate pair. Abdomen black, last three segments polished on their broad apices, white pollinose bands on anterior half of the segments which are not sharply defined from the black and are prologned laterally and ventrally to near median ventral line; abdomen clothed with usual black appressed hairs which extend well into the pollinose areas from behind; first segment without bristles, second with one lateral and one strong median marginal pair, third and fourth each with uninterrupted marginal rows of about eight, the bristles of the third scarcely equalling those of the fourth segment. Genitalia in repose, largely concealed within abdomen, normally extruding one-fourth length of fourth abdominal segment; claws of inner forceps flattened and united near the tip; outer forceps becoming slender near apex, then suddenly expanded into sharp-pointed, plow-shaped tips. Wings slightly infuscated; section of fourth vein beyond bend strongly arcuate; hind cross vein oblique to last section of fourth vein which it joins about two-fifths distance from the bend to the small cross vein; a small costal spine present; three to five small bristles on third vein extending about half way from its base to small cross vein. Legs black; pulvilli of fore feet varying from subequal to slightly longer than last tarsal joint; middle tibia with one bristle on outer front side near middle; hind tibia on outside with two or three unequal bristles not extending far beyond the middle.

Female.-Front at narrowest 0.385 of head width (in two specimens measuring 0.38 and 0.39 respectively); third antennal joint three and one-half to four times length of second. Genitalia of usual nonpiercing type almost wholly concealed within the abdomen. Otherwise like the male.

Length, 4.0 to $6.0 \mathrm{~mm}$.

Host relationships.-Unknown.

Redescribed from the type which is a male from southern Florida, loaned from the University of Kansas Museum and several other specimens as follows: In the collection of the National Museum, one female from southern Florida labeled "Gymnoprosopa"; one 
male from Opelousas, Louisiana, May 1907; two females from Lafayette, Indiana, labeled July 12 and July 16, 1915 (J. M. Aldrich). In the collection of Nathan Banks, one female, July 4, two males and one female, July 12 from honeydew on tulip tree, one female on August 30 from honeydew on tulip tree, and another specimen on May 31, all from Falls Church, Virginia, collected by Nathan Banks. In my collection, one male from Starksville, Mississippi, May 10, 1923 (H. W. Chalkley).

GYMNOPROSOPA FILIPALPUS, new species

Male.-Front at narrowest 0.355 of head width (measurements of two 0.35 and 0.36 respectively); frontal vitta reddish-yellow, its sides parallel or sometimes widest at the middle where the width equals three to five times that of the parafrontal; six strong bristles in the frontal row; one reclinate and two proclinate orbital bristles; parafrontals silvery pollinose over yellow, all of face and bucca silvery; bristly black hairs extend from the orbitals down over parafacials to lower end of eyes; vibrissae not more than half length of second antennal joint above front edge of oral margin; facial ridges bare save for one or two hairs just above insertion of vibrissae; antennae extend almost to vibrissae; second joint dark brown to yellowish; third joint black, three and one-half to five times length of second; arista thickened on basal third; in profile, head length at vibrissae much less than at base of antennae, buccal width equals one-fourth eye height; proboscis two-thirds as long as head height; palpi pale-yellow, nearly filiform. Thorax gray pollinose over black with three shining black vittae of which the outer two are broad, the inner one much narrower; scutellum with three pairs of marginal bristles of which the lateral and apical pairs are equal, both much smaller than the intermediate pair. Abdomen shining black; segments two to four with gray pollen on their basal third; first segment without bristles, second with one lateral and one median marginal pair, the third and fourth each with a marginal row of six strong bristles. Genitalia in repose, almost completely concealed within abdomen; both genital segments black, sparsely covered with bristly hairs of the same size as those of the abdomen, first segment with a subapical row of about four distinct bristles; inner forceps black, sparsely covered with black bristly hairs, bulbous at base, tapering abruptly to slender tips which when viewed from behind are half as long as the basal part, claws moderately divergent at the tips; outer forceps yellow, as long as the inner pair, slender on apical half, slightly clavate at tip, curved gently towards tips of inner forceps. Wings infuscated towards costal margin, anal margin hyaline; section of fourth vein beyond the bend strongly arcuate; posterior cross vein perpendicular to fourth vein which it joins nearly halfway between 
the bend and the small cross vein; one strong costal spine; third vein with three to four bristles which extend more than half way from its base to the small cross vein. Legs black; pulvilli of fore feet usually distinctly longer than last tarsal joint; middle tibia with a single bristle on outer front side near the middle; hind tibia on outside with two to four unequal bristles not extending far beyond the middle.

Female.-Front at narrowest 0.34 of head width (measurements of six $0.33,0.33,0.34,0.35,0.35,0.35$, respectively); pulvilli short, those of fore feet much shorter than last tarsal joint; genitalia of usual type and largely concealed within abdomen. Otherwise like the male.

Length, 3.5 to $5.5 \mathrm{~mm}$.

Type and allotype.-Cat. No. 28163, U.S.N.M., type, male, McHenry, Mississippi. Allotype, female, Miami, Florida, September 8. Host relationships.-Unknown.

Range.-Virginia, Georgia, Mississippi, Florida.

Described from the following material: In the National Museum, one male and three females from Georgia; one male from Enterprise, Florida; seventeen females from Miami, Florida, taken on several dates in September (C. H. T. Townsend) ; one male from McHenry, Mississippi, September 11, 1922 (H. W. A.). In the collection of Nathan Banks, three females from Falls Church, Virginia, June 2, July 4, and September 13, respectively, labeled "on chinquipin" (N. Banks). In the collection of J. R. Malloch, one male labeled June 24, and one female, June 17, Bancroft, Virginia, from flowers of Ceanothus americanus (W. L. McAtee).

GYMNOPROSOPA PALLIDA, new species

Male.-Front at narrowest measured in one specimen 0.36 of head width; inner orbits strongly narrowed at base of antennae; all of face and front including the vitta silvery pollinose, with dark reflections at the vertex; vitta pale yellow when viewed from above, moderately divergent from base of antennae to vertex, at level of lowest orbitals four to five times width of parafrontal; about nine bristles in frontal row; one reclinate and two proclinate orbital bristles; parafrontals beset with bristly hairs; vibrissae at level of oral margin; antennae black, extending five-sixths distance to vibrissae, third joint four times length of second; arista thickened on basal three-fifths; facial ridges divergent, with only one or two microscopic hairs just above the vibrissae; in profile, bucca narrower than parafacials and equal to one-eighth eye height, front projects over one-third eye diameter, head length at vibrissae much less than at base of antennae; palpi yellow with blackish tips, strongly clavate. Thorax thinly gray pollinose over black, with five obscure black vittae of which the outer two are broader than the three narrow median ones; scutellum with three pairs of marginal bristles, the lateral pair distinctly larger than 
the apicals and both smaller than the strong intermediate pair; preapicals present. Abdomen black, sides of first and second segment dull-reddish; last three segments with a pollinose band on the basal half, which is invaded from behind by many bristly hairs; first two segments each with a median marginal pair of bristles, the third with a median marginal pair and two or three laterals, the fourth with a marginal row of about ten bristles; macrochaetae of middle segments of the same size as those of fourth segment. Genitalia black, in repose largely concealed within tip of abdomen and not visible from the side. Wings hyaline; hind cross vein nearly parallel to section of fourth vein beyond the bend; costal spine lacking; one bristly hair at base of third vein. Legs black; pulvilli of fore feet less than onefourth length of last tarsal joint; middle tibia with a single bristle on outer front side near the middle; hind tibia with four to five unequal bristles on outside extending to slightly beyond the middle.

Length, $4.0 \mathrm{~mm}$.

Type.-Male, Cat. No. 28164, U.S.N.M.

Host relationships.-Unknown.

Described from a single male from Horseshoe Bend, Idaho, collected by Dr. J. M. Aldrich in 1900.

\section{GYMNOPROSOPA INFLATICORNIS, new species}

Female.-Front at narrowest 0.4 of the head width from measurements of two which were 0.40 and 0.40 respectively; frontal vitta yellow, sides parallel or slightly expanded at the middle where width of vitta is three times that of parafrontal; parafrontals gray pollinose, merging into silvery pollinose on face and bucca; about ten bristles in the frontal row, those at the back scarcely larger than the parafrontal hairs which are most densely grouped just anterior to the lowest ocellus, where a few hairs occur on the frontal vitta between the frontal rows; one reclinate and three or four proclinate orbital bristles; vibrissae level with front edge of oral margin; facial ridges with a small cluster of bristly hairs on the lowest fifth; antennae extend five-sixths distance from their base to the vibrissae; second joint brown; third joint black, inflated saclike, conspicuously pitted, not pointed at the outer apical angle, from three and onehalf to four times length of second joint; arista thickened on basal half; parafacials sparsely beset with black bristly hairs, continuous from parafrontals; in profile, bucca equals one-third eye height; proboscis distinctly shorter than head height; palpi clavate, yellow with blackish tips. Thorax gray pollinose over black, with three obscure vittae; scutellum with three pairs of marginal bristles of about equal size and a somewhat smaller preapical pair. Abdomen shining black, last three segments with white pollinose bands sharply defined from the black and confined to basal half of the segment but 
prolonged laterally and ventrally to near the median ventral line; second segment with a lateral and one median marginal pair of bristles, third and fourth each with a marginal row of about eight; all abdominal macrochaetae weak, being comewhat shorter than the segment upon which they occur. Wings hyaline; fourth vein beyond bend but slightly arcuate, parallel to hind cross vein; last section of fifth vein equals one-third preceding section; one very small costal spine; three or four small bristles on third vein extending scarcely halfway to small cross vein. Legs black; pulvilli distinctly shorter than the last tarsal joint; middle tibia with one bristle on outer front side near middle; hind tibia on outside with row of six to nine unequal bristles, extending considerably below the middle.

Male.-Not known.

Length, 4.0 to $5.0 \mathrm{~mm}$.

Type-Female. Cat. No. 28165, U.S.N.M. Pecos, New Mexico. Host relationships.-Unknown.

Described from two females in the National Museum from the following localities: Pecos, New Mexico, September. 5 (Cockerell); Las Vegas, New Mexico, 1918, labeled “T. D. 4430” (H. S. Barber).

\section{EXPLANATION OF PLATES}

Plate 1

a $c=$ anterior claspers; $i f=$ inner forceps; $o f=$ outer forceps; $p=$ penis; $p c=$ posterior claspers.

FIG. 1. Male genitalia of Metopia leucocephala Rossi.

2. Male genitalia of Metopia campestris Fallén.

3. Male genitalia of Hilarella hilarella Zetterstedt.

4. Male genitalia of Sphenometopa tergata Coquillett.

5. Male genitalia of Opsidia gonioides Coquillett.

6. Male genitalia of Phrosinella fulvicornis Coquillett.

Plate 2

For explanation of letter see Plate 1.

Fig. 7. Male genitalia of Senotainia trilineata Van der Wulp.

8. Male genitalia of Senotainia rubriventris Macquart.

9. Male genitalia of Senotainia flavicornis Townsend.

10. Male genitalia of Senotainia litoralis Allen.

11. Male genitalia of Senotainia vigilans Allen.

12. Male genitalia of Pachyophthalmus floridensis Townsend.

Plate 3

For explanation of letters see Plate 1.

Fig. 13. Male genitalia of Pachyophthalmus signatus Meigen

14. Male genitalia of Pachyophthalmus distortus, new species.

15. Fore tarsus of male, Phrosinella pilosifrons, new species, viewed from the side. 
Fig. 16. Fore tarsus of male, Phrosinella aldrichi, new species, viewed from the inside.

17. Fore tarsus of female, Phrosinella fulvicornis Coquillett, viewed from above.

18. Fore tarsus of male, Sphenometopa nebulosa Coquillett, viewed from the side

19. Fore tarsus of male, Metopia campestris Fallén, viewed from above.

\section{Plate 4}

a $g=$ accessory gland; $a p=$ accessory pouch of uterus; $o=$ ovary; $o d=$ oviduct; $s=$ spermatheca $; u=$ uterus

Fig. 20. Reproductive organs of female, Senotainia trilineata Van der Wulp.

21. Puparium of Senotainia vigilans Allen, Dorsal aspect.

22. Reproductive organs of female, Senotainia vigilans.

23. Head of Senotainia vigilans.

24. Wing of Senotainia vigilans.

25. Reproductive organs of female, Senotainia litoralis Allen.

26. Egg (from uterus) of Opsidia gonioides Coquillett.

\section{Plate 5}

FIG. 27. Posterior end of puparium of Senotainia vigilans Allen. $d=$ spiracular depression; $s l=$ slits in posterior spiracle; $s t=$ posterior spiracle or stigma

28. Second instar larva of Senotainia trilineata Van der Wulp. Lateral aspect of anterior end. I, II, and III=thoracic segments; $a s=$ anterior spiracle.

29. Buccopharyngeal armature of the first instar (uterine) larva of Phrosinella fulvicornis Coquillett. $b p=$ basal piece; $l h=$ lateral hooks; $m h=$ median hook; $p$ - $H=\mathrm{H}$-piece.

30. Buccopharyngeal armature of the first instar (uterine) larva of Senotainia rubriventris Macquart. For explanation of letters see fig. 29.

31. Buccopharyngeal armature of the first instar (uterine) larva of Senotainia trilineata Van der Wulp. For explanation of letters see fig. 29 .

32. Buccopharyngeal armature of the first instar (uterine) larva of Senotainia litoralis Allen. For explanation of letters see fig. 29.

33. Buccopharyngeal apparatus of the first instar (uterine) larva of Senotainia vigilans. For explanation of letters see fig. 29.

34. Buccopharyngeal armature of the second instar larva of Senotainia trilineata showing the lateral hooks of the succeeding instar in process of formation. a $p=$ accessory process of the basal piece; $b p=$ basal piece; $i p=$ intermediate or H-piece; $l h=$ lateral hooks; $l h I I I=$ lateral hooks of the third instar partly formed.

35. Diagramatic outline of spiracular depression at posterior end of puparium of Phrosinella fulvicornis. For explanation of letters see fig. 27. 
U. S. NATIONAL MUSEUM
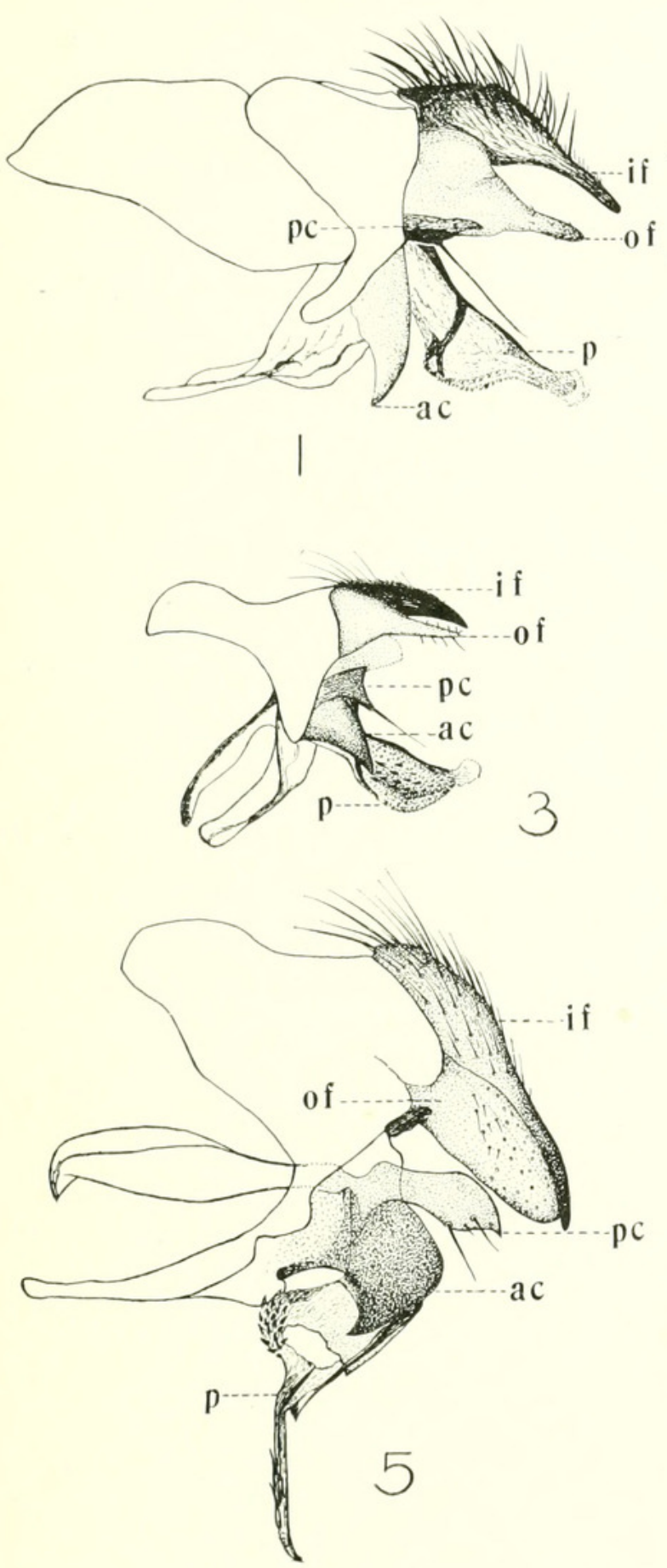

PROCEEDINGS, VOL. 68, ART. 9 PL. I
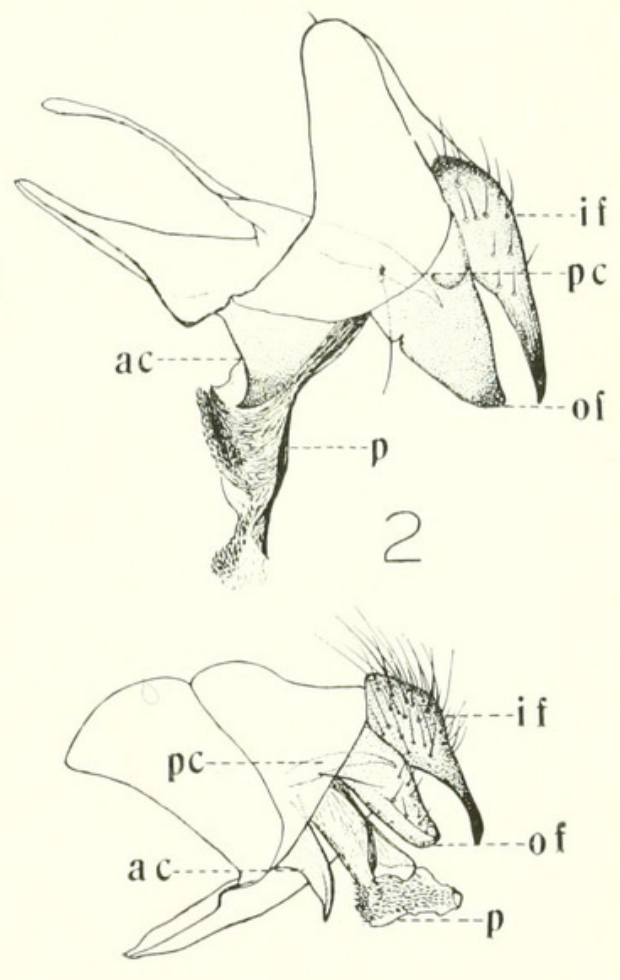

4

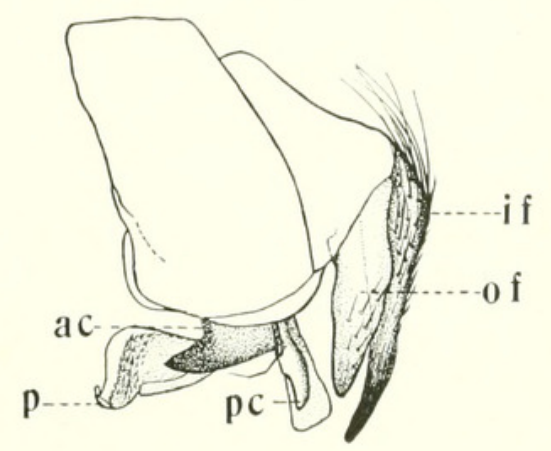

6

AMERICAN SPECIES OF TWO-WINGEd FLIES OF THE TRIBE MILTOGRAMmiNI For Explanation of PLATE SEe Page 103 
U. S. NATIONAL MUSEUM
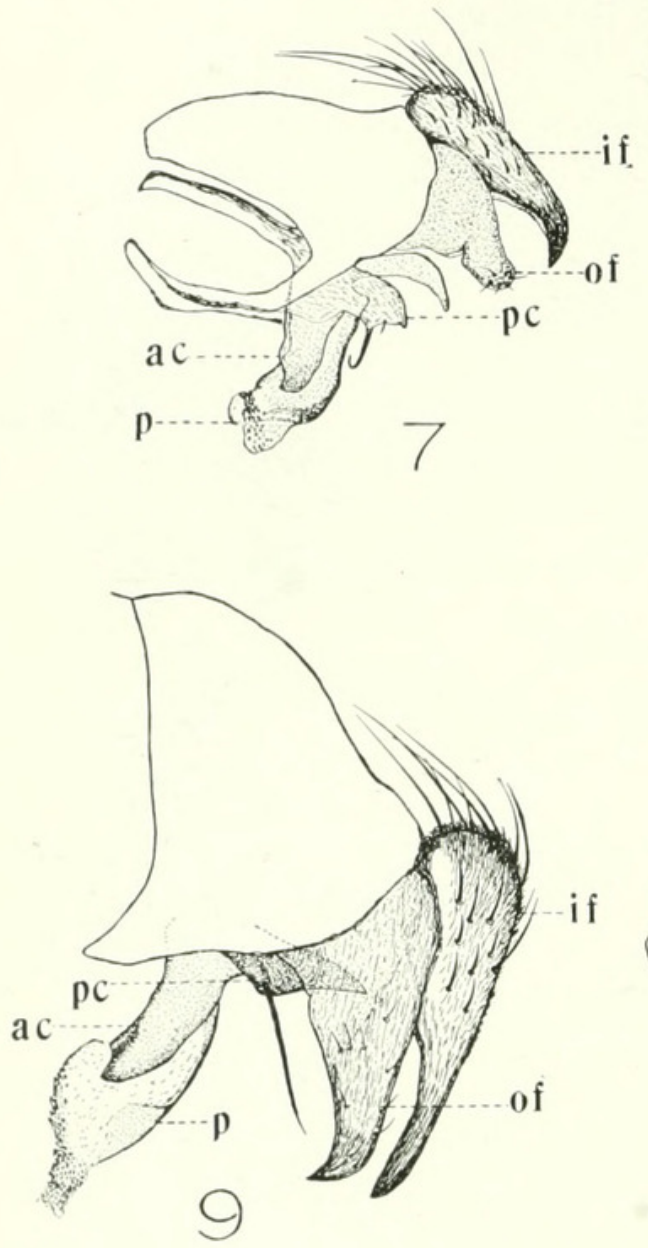

9

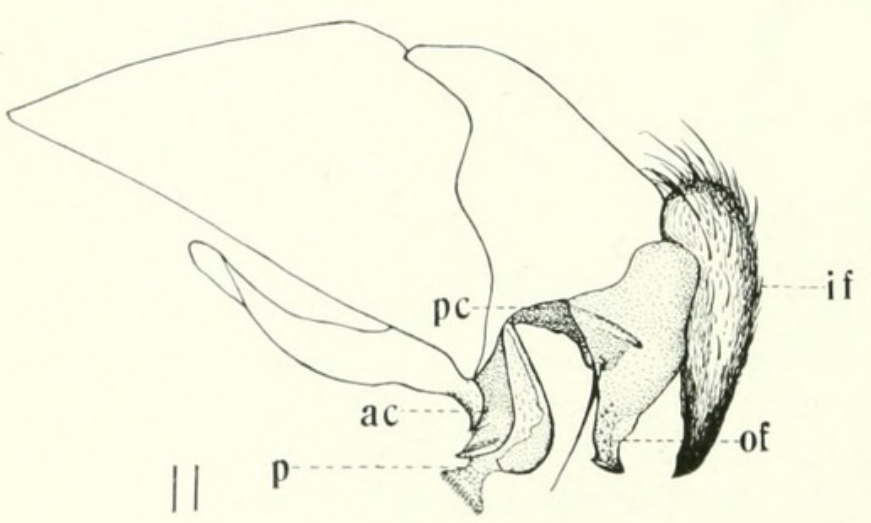

PROCEEDINGS, VOL. 68 , ART. 9 PL. 2

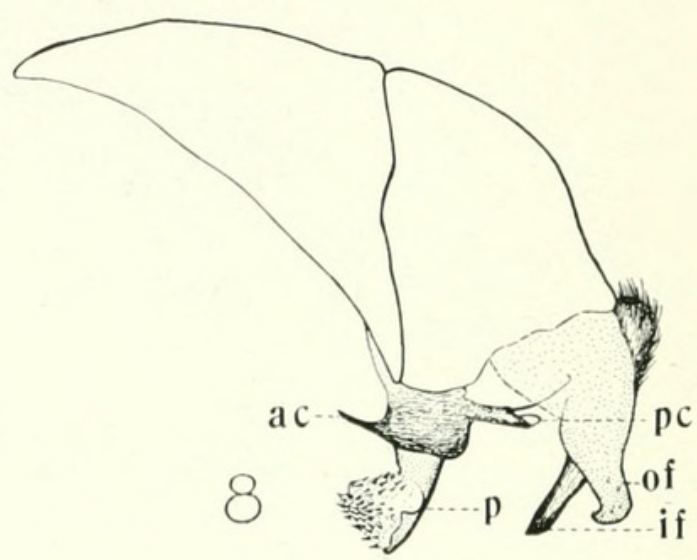

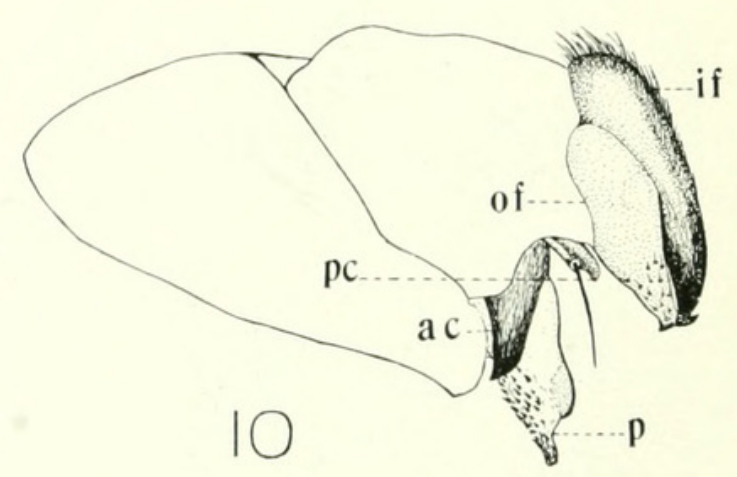

American Species of TWo-Winged Flies of the Tribe Miltogrammini 

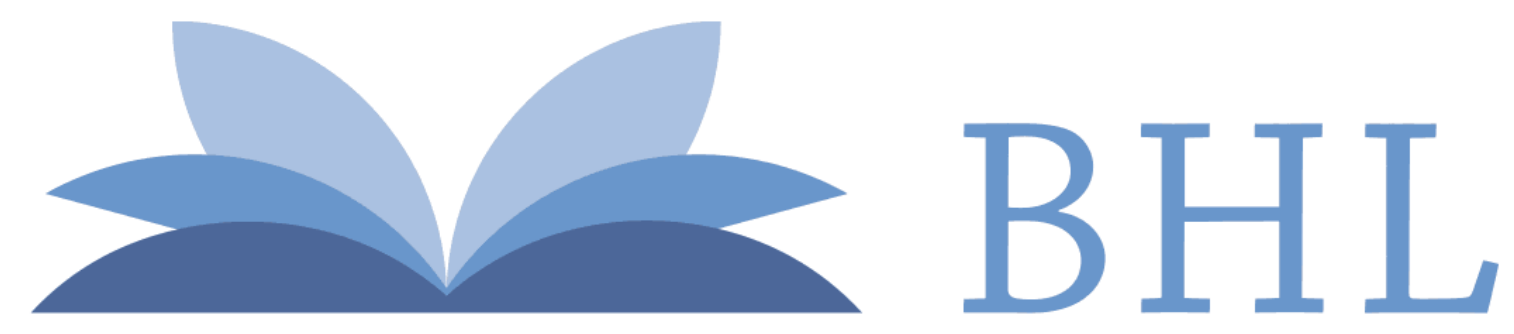

\section{Biodiversity Heritage Library}

Allen, Harry W. 1926. "North American species of two-winged flies belonging to the tribe Miltogrammini." Proceedings of the United States National Museum 68(2610), 1-106. https://doi.org/10.5479/si.00963801.68-2610.1.

View This Item Online: $\underline{\text { https://www.biodiversitylibrary.org/item/32569 }}$

DOI: https://doi.org/10.5479/si.00963801.68-2610.1

Permalink: https://www.biodiversitylibrary.org/partpdf/5753

\section{Holding Institution}

Smithsonian Libraries

\section{Sponsored by}

Smithsonian

\section{Copyright \& Reuse}

Copyright Status: NOT_IN_COPYRIGHT

Rights: https://www.biodiversitylibrary.org/permissions/

This document was created from content at the Biodiversity Heritage Library, the world's largest open access digital library for biodiversity literature and archives. Visit BHL at https://www.biodiversitylibrary.org. 